\title{
Accelerated Irradiation Test of Gundremmingen Reactor Vessel Trepan Material
}

Manuscript Completed: May 1992

Date Published: August 1992

Prepared by

J. R. Hawthorne

Materials Engineering Associates, Inc.

9700-B Martin Luther King, Jr. Highway

Lanham, MD 20706-1837

Prepared for

Division of Engineering

Office of Nuclear Regulatory Research

U.S. Nuclear Regulatory Commission

Washington, DC 20555

NRC FIN D5848 
ABSTRACT

Initial mechanical properties tests of beltline material trepanned from the decommissioned KRB-A pressure vessel and archive material irradiated in the UBR test reactor revealed a major anomaly in relative radiation embrittlement sensitivity. Poor correspondence of material behavior in test vs. power reactor environments was ubserved for the weak test orientation (ASTM L-C) whereas correspondence was good for the strong orientation (ASTM C.L). To resolve the anomaly directly, Charpy- $V$ specimens from a low (essentially-nil) fluence region of the vessel. were irradiated together with archive material at $279^{\circ} \mathrm{C}$ in the UBR test reactor.

Properties tests before UBR irradiation revealed a significant difference in $41-\mathrm{J}$ transition temperature and upper shelf energy level between the materials. However, the materials exhibited essentially the same radiation embrittlement sensitivity (both orientations), proving that the anomaly is not due to a basic difference in material irradiation resistances. Possible causes of the original anomaly and the significance to NRG Regulatory Guide 1.99 are discussed.

Key Words: Charpy V-notch, Fluence-Rate Effects, Nuclear Reactors, Pressure Vessels, Radiation Embrittlement, Steel. 


\section{INTRODUCTION :}

The 250-MW bolling water Gundremingen Reactor, KRB-A, located in the Federal Republic of Germany (FRG) was decommissioned by the utility owners in 1977. Prior to its decomissioning, the reactor vessel operated at a nominal temperature of $-288^{\circ} \mathrm{C}$ and had an Inner wall fluence of about $3 \times 10^{18} \mathrm{n} / \mathrm{cm}^{2}$, $E>1 \mathrm{MeV}$ (Ref. 1). In 1984, a remnant of a forging believed to be from the vessel construction was located by the U. S. Nuclear Regulatory Commission (NRC). The availability of this "archive" materlal and the service-degraded vessel material presented anique opportunity for qualifying the effects of long-term frradiation on a prototypic reactor pressure vessel (RPV) steel. Specifically, the materials allowed direct testing of the effect of fluence rate (dose rate) on the degradation of Charpy $-V\left(C_{v}\right)$ notch ductility and fracture toughness properties and the elevation of yleld strength by neutron radiation. In addition, the materials permitted verification tests of present. prediction methods for radiation-induced embrittlement (Ref, 2,3) and the attenuation of radiation effects through the vessel thickness (Ref. 2). The NRC subsequentiy put in place a foint USA/FRG program to (a) investigate the vessel's properties and (b) conduct accelexated irradiation tests of the archive material for power vs. test reactor comparisons. Materials Engineering Associates (MEA) and Material Pruefungsanstalt (MPA) were the lead laboratories for the two countries, respectively.

Qualification tests of the archive material located in storage at the General Electric Company provided evidence which, when coupled with vessel documentation, led to conclusions by MEA and MPA that (a) the base metal and Vessel Forging No. 7.1 were from the same steel melt and (b) the base metal is representative of the vessel forging as first placed in service (Ref. 4). The material was in the form of two circumferentially-welded ring segments; the weld is suspected of being a portion of the weld made for the reactor vessel surveillance program. One ring segment, approximately $119-\mathrm{mm}$ thick and weighing about $1450 \mathrm{~kg}$, was used for the primary MEA investigations of irradiation behavior. It is identifled in this report as the Code GEB material. The chemical composition of the GEB base material and that of the vessel's Forging Ring No. 7 are given in Table 1 and are identical for practical purposes. Composition test results for the base metal used in the reactor survelllance program also are indicated. The reactor surveillance program was in place at the comnencement of initial commercial operations; however, only ASTM C.I orientation base metal specimens (strong orientation) were fncluded in the survelllance capsules along with the weld metal and heat affected zone (HAZ) specimens. This was the recommendation of ASTM Practice E 185 in the early $1960^{\circ} \mathrm{s}$. 
CONTENTS

$\underline{\text { Page }}$

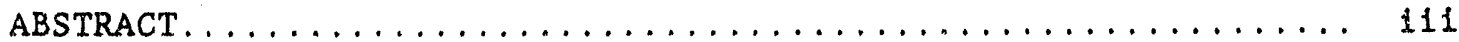

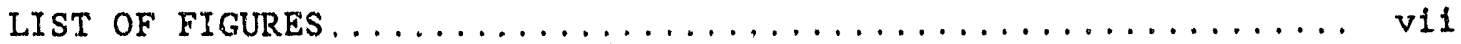

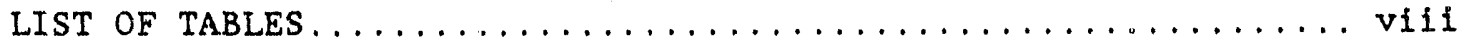

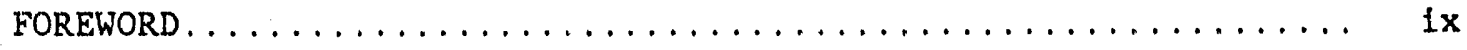

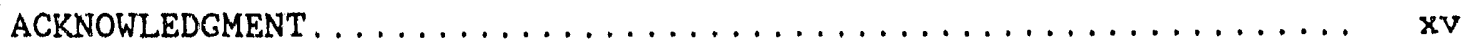

1. INTRODUCIION $\ldots \ldots \ldots \ldots \ldots \ldots \ldots \ldots \ldots \ldots \ldots \ldots \ldots \ldots \ldots$

2. THE ANOMALY ...........................

3. APPROACH $\ldots \ldots \ldots \ldots \ldots \ldots \ldots \ldots \ldots \ldots \ldots \ldots \ldots \ldots \ldots \ldots \ldots$

4. NATERIALS SAMPLING FOR THE UBR IRRADIATION TEST......... 9

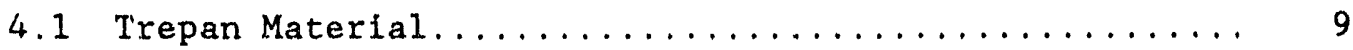

4.2 Archive Material.......................... 9

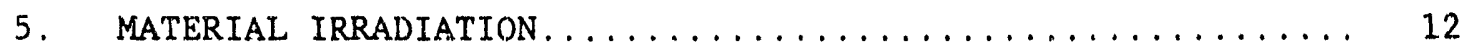

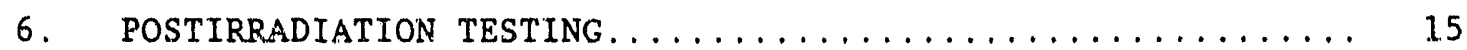

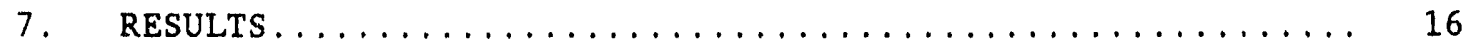

7.1 Archive Material ....................... 16

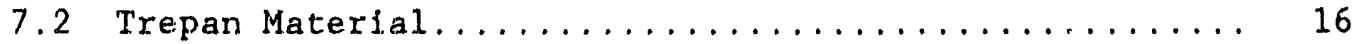

7.3 Trepan vs. Archive Material.................. 16

7.4 Trepan Data (Inner Wall vs. Outer Wall Layers - ${ }_{\text {Preservice Condition) } \ldots \ldots \ldots 22}$

7.5 Trepan Data (Inner Wall-Postservice vs. Outer

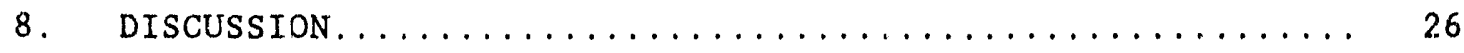

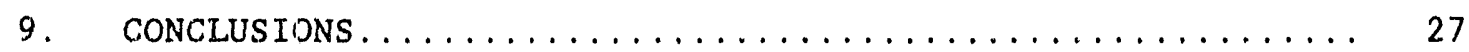

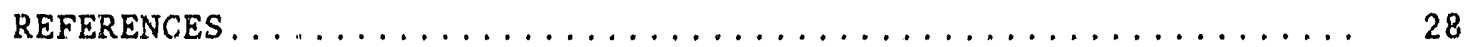

Appendix A Neutron Dosimetry Determinations Based on Fission Spectrum Assumption for Irradiation Experiment UBR $-83 A \ldots \ldots \ldots \ldots \ldots \ldots \ldots \ldots$ A -1

Appendix B Reactor Operations History: Irradiation Assembly

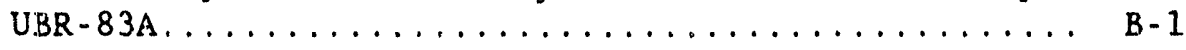

Appendix $\mathrm{C}$ Charpy.V Data Tabulations and Computer Curve Fits for Unirradiated Condition Tests and Irradiation Experiment UBR-83A Tests.................. C-1 
1 Charpy-V notch ductility of KRB-A vessel material before and after irradiation service................... 4

2 Embrittlement of the archive material by a fluence matching that of the KRB-A vessel..................... 5

3 Charpy $-V$ specimen cutting plan for Trepan P........... 10

4 Placement of specimens and dosimeters in Irradiation Assembly UBR $-83 \mathrm{~A} \ldots \ldots \ldots \ldots \ldots \ldots \ldots \ldots \ldots \ldots \ldots \ldots$

5 Thernocouple placements in the Irradiation Assembly UBR-83A................................ 14

6 Notch ductility of the archive material before and after irradiation in Assembly UBR $-83 \mathrm{~A} \ldots \ldots \ldots \ldots \ldots \ldots \ldots \ldots$

7 Postirradiation Charpy $-V$ data for the archive material from two UBR assemblies showing properties reproduceability..... 19

8 Notch ductility of the trepan material vs. the archive material after irradiation in Assembly UBR-83A......... 20

9 Notch ductility of the trepan material after irradiation in the UBR reactor findexed to the post $\mathrm{KRB}-\mathrm{A}$ service

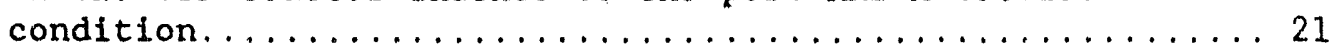

10 Notch ductility of the trepan material vs. the archive material before irradiation in the UBR.............. 23

11 Notch ductility of the trepan material after KRB-A service (inner-wall location) vs. UBR accelerated irradiation

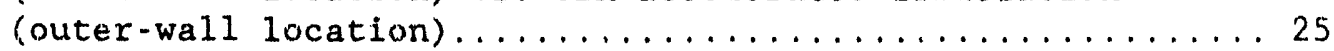




\section{LIST OF TABLES}

Tables

Page

1 Chemical Compositions of Materials................ 2

2 LT vs. TL Orientation Embrittlement Data.............6

3 Neutran Fluences Received by Trepans P, C, D and G

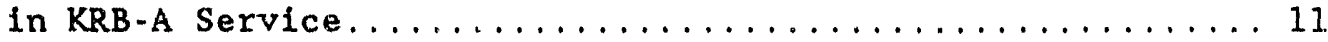

4 Charpy $-V$ Notch Ductility Determinations Before and After

UBR Irradiation.......................... 17 
The work reported here was performed at Materials Engineering Associates (MEA) under the program, Irradiation Embrittlement of Reactor Pressure Vessel Steels, F. J. Loss, Program Manager. The program is sponsored by the Office of Nuclear Regulatory Research of the U. S. Nuclear Regulatory Commission (NRC). The technical monitor for the NRC is E. M. Hackett.

Reports under the prior contract, Structural Integrity of Water Reactor Pressure Boundary Components, are listed below:

1. J. R. Hawthorne, "Significance of Nickel and Copper Content to Radiation Sensitivity and Postirradiation Heat Treatment Recovery of Reactor Vessel Steels," USNRC Report NUREG/CR-2948, Nov. 1982.

2. "Structural. Integrity of Water Reactor Pressure Boundary Components, Annual Report for 1982," F. J. Loss, Ed., USNRC Report NUREG/CR-3228, Vo1. 1, Apr. 1983.

3. J. R. Hawthorne, "Exploratory Assessment of Postirradiation Heat Treatment Variables in Notch Ductility Recovery of A 533-B Stee1," USNRC Report NUREG/CR-3229, Apr. 1983.

4. W. H. Cullen, K. Torronen, and M. Kemppainen, "Effects of Temperature on Fatigue Crack Growth of A 508-2 Steel in LWR Environment," USNRC Report NUREG/CR-3230, Apr. 1983.

5. "Proceedings of the International Atomic Energy Agency Specialists' Meeting on Subcritical Crack Growth," Vols. 1 and 2, W. H. Cullen, Ed., USNRC Conference Proceeding NUREG/CP-0044, May 1983.

6. W. H. Cullen, "Fatigue Crack Growth Rates of A 508-2 Steel in Pressurized, High-Temperature Water," USNRC Report NUREG/CR-3294, June 1983.

7. J. R. Hawthorne, B. H. Menke, and A. L. Hiser, "Light Water Reactor Pressure Vessel Survelllance Dosimetry Improvement Program: Notch Ductility and Fracture Toughness Degradation of A 302-B and A 533-B Reference Plates from PSF Simulated Surveillance and Through-Wall Irradiation Capsules," USNRC Report NUREG/CR-3295, Vo1. 1, Apr. 1984.

8. J. R. Hawthorne and B. H. Menke, "Light Water Reactor Pressure Vessel Sirveillance Dosimetry Improvement Program: Postirradiation Notch Ductility and Tensile Strength Determinations for PSF Simulated Surveillance and Through-Wall Specinen Capsules," USNRC Report NUREG/CR-3295, Vol. 2, Apr. 1984.

9. A. L. Hiser and F. J. Loss, "Alternative Procedures for J-R Curve Determination," USNRC Report NUREG/CR-3402, July 1983. 
10. A. L. Hiser, F, J. Loss, and B. H. Menke, "J-R Curve Characterization of Irradiated Low Upper Shelf Welds," USNRC Report NUREG/CR-3506, Apr. 1984.

11. W. H. Cullen, R. E. Taylor, K. Torronen, and M. Kemppainen, "The Temperature Dependence of Fatigue Crack Growth Rates of A 351 CF8A Cast Stainless Steel in LWR Environment," USNRC Report NUREG/CR-3546, Apr. 1984.

12. "Structural Integrity of Light Water Reactor Pressure Boundary Components -- Four-Year Plan 1984-1988," F. J. Loss, Ed., USNRC Report NUREG/CR-3788, Sep. 1984.

13. W. H. Cullen and A. L. Hiser, "Behavior of Subcritical and SlowStable Crack Growth Following a Postirradiation Thermal. Anneal Cycle," USNRC Report NUREG/CR-3833, Aug. 1984.

14. "Structural Integrity of Water Reactor Pressure Boundary Components: Annual Report for 1983," F. J. Loss, Ed., USNRC Report NUREG/CR-3228, Vo1. 2, Sept. 1984.

15. W. H. Cullen, "Fatigue Crack Growth Rates of Low-Carbon and Stainless Piping Steels in PWR Enwironment," USNRC Report NUREG/CR-3945, Feb. 1985.

16. W. H. Cullen, M. Kemppainen, H. Hanninen, and K. Torronen, "The Effects of Sulfur Chemistry and Flow Rate on Fatigue Crack Growth Rates in LWR Environments," USNRC Report NUREG/CR-4121, Feb. 1985.

17. "Structural Integrity of Water Reactor Pressure Boundary Components: Annual Report for 1984," F. J. Loss, Ed., USNRC Report NUREG/CR-3228, Vol. 3, June 1985.

18. A. I. Hiser, "Correlation of $\mathrm{C}_{\mathrm{y}}$ and $\mathrm{K}_{\mathrm{Ic}} / \mathrm{K}_{\mathrm{JC}}$ Transition Temperature Increases Due to Irradiation," USNRC Report NUREG/CR-4395, Nov. 1985.

19. W. H. Cullen, G. Gabetta, and H. Hanninen, "A Review of the Models and Mechanisms For Environmentally-Assisted Crack Growth of Pressure Vessel and Piping Steels in PWR Environments, "USNRC Report NUREG/CR-4422, Dec. 1985.

20. "Proceedings of the Second International Atomic Energy Agency Specialists' Meeting on Subcritical Cxack Growth," W. H. Cullen, Ed., USNRC Conference Proceeding NUREG/CP-0067, Vols. 1 and 2 , Apr. 1986.

21. J. R. Hawthorne, "Exploratory Studies of Element Interactions and Composition Dependencies in Radiation Sensitivity Development," USNRC Report NUREG/CR-4437, Nov. 1985. 
22. R. B. Stonesifer and E. F. Rybicki, "Development of Models for Warm Prestressing," USNRC Report NUREG/CR-4491, Jan. 1987.

23. E. F. Rybicki and R. B. Stonesifer, "Computational Model. for Residual Stresses in a Clad Plate and Clad Fracture Specimens," USNRC Report NUREG/CR-4635, Oct. 1986.

24. D. E. McCahe, "Plan for Experimental Characterization of Vessel Clad Steel After Irradiation," USNRC Report NUREG/CR-4636, Oct. 1986.

25. E. F. Rybicki, J. R. Shadley, and A. S. Sandhu, "Experimental Evaluation of Residial Stresses in a Weld Clad Plate and Clad Test Specimens," USNRC Report NUREG/CR-4646, Oct. 1986.

26. "Structural Integrity of Water Reactor Pressure Boundary Components: Annual Report for 1985," F. J. Loss, Ed., USNRC Report NUREG/CR-3228, Vo1. 4, June 1986.

27. G. Gabetta and W. H. Cullen, "Application of a Two-Mechanism Model for Environmentally-Assisted Crack Growth," USNRC Report NUREG/CR-4723, Oct. 1986.

28. W. H. Cullen, "Fatigue Crack Growth Rates in Pressure Vessel and Piping Steels in LWR Environments," USNRC Report NUREG/CR-4724, Mar. 1987.

29. W. H. Cullen and M. R. Jolles, "Fatigue Crack Growth of PartThrough Cracks in Pressure Vessel and Piping Steels: Air Environment Results, USNRC Report NUREG/CR-4828, Oct. 1988.

30. D. E. McCabe, "Fracture Evaluation of Surface Cracks Embedded in Reactor Vessel Cladding: Unirradiated Bend Specimen Results," USNRC Report NUREG/CR-4841, May 1987.

31. H. Hanninen, M. Vulli, and W. H. Cullen, "Surface Spectroscopy of Pressure Vessel Steel Fatigue Fracture Surface Films Formed in PWR Environments," USNRC Report NUREG/CR-4863, July 1987.

32. A. L. Hiser and G. M. Callahan, "A User's Guide to the NRC's Piping Fracture Mechanics Data Base (PIFRAC)," USNRC Report NUREG/CR-4894, May 1987.

33. "Proceedings of the Second CSNI Workshop on Ductile Fracture Test Methods (Paris, France, April 17-19, 1985)," F. J. Loss, Ed., USNRC Conference Proceeding NUREG/CP-0064, Aug, 1988.

34. W. H. Cullen and D. Broek, "The Effects of Variable Amplitude Loading on A 533-B Steel in High-Temperature Air and Reactor Water Environments," USNRC Report NUREG/CR-4929, Apr. 1989.

35. "Structural Integrity of Water Reactor Pressure Boundary Components: Annual Report for 1986," F. J. Loss, Ed., USNRC Report NUREG/CR-3228, Vol. 5, July 1987. 
36. F. Ebrahimi, et al., "Development of a Mechanistic Understanding of Radiation Embrittlement in Reactor Pressure Vessel Steels: Final Report," USNRC Report NUREG/CR-5063, Jan. 1988.

37. J. B. Terrell, "Fatigue Life Characterization of Smooth and Notched Piping steel Specimens in $288^{\circ} \mathrm{C}$ Air Environments, "USNRC Report NUREG/CR-5013, May 1988.

38. A. L. Hiser, "Tensile and $J-R$ Curve Characterization of Thermally Aged Cast Stainless Steels," USNRC Report NUREG/CR-5024, Sept. 1988

39. J. B. Terre11, "Fatigue Strength of Smooth and Notched Specimens of ASME SA 106-B Steel in PWR Environments," USNRC Report NUREG/CR-5136, Sept. 1988.

40. D. E. McCabe, "Fracture Evaluation of Surface Cracks Embedded in Reactor Vessel Cladding: Material Property Evaluations" USNRC NUREG/CR-5207, Sept. 1988.

41. J. R. Hawthorne and A. L. Hiser, "Experimental Assessments of Gundremmingen RPV Archive Material for Fluence Rate Effects Studies," USNRC Ruport NUREG/CR-5201, Oct. 1988.

42. J. B. Terrel1, "Fatigue Strength of ASME SA 106-B Welded Steel Pipes in $288^{\circ} \mathrm{C}$ Air Environments," USNRC Report NUREG/CR-5195, Dec. 1988 .

43. A, L. Hiser, "Post-Irradiation Fracture Toughness Characterization of Foux Lab-Melt Plates," USNRC Report NUREG/CR-5216, Rev. 1, June 1989.

44. R. B. Stonesifer, E. F. Rybicki, and D. E. McCabe, "Warm Prestress Modeling: Comparison of Models and Experimental Results," USNRC Report NUREG/CR-5208, Apr. 1989.

45. A. L. Hiser and J. B. Terrell, "Size Effects on J-R Curves for A 302-B Plate," USNRC Report NUREG/CR-5265, Jan. 1989.

46. D. E. McCabe, "Fracture Evaluation of Surface Cracks Embedded in Reactor Vessel Cladding," USNRC Report NUREG/CR-5326, Mar. 1989.

47. J. R. Hawthorne, "An Exploratory Study of Element Interactions and Composition Dependencies in Radiation Sensitivity Development: Final Report," USNRC Report NUREG/CR-5357, Apr. 1989

48. J. R. Hawthorne, "Steel Impurity Element Effects on Postirradiation Properties Recovery by Annealing: Final Report," USNRC Report NUREG/CR-5388, Aug. 1989.

49. J. R. Hawthorne, "Irradiation-Anneal-Reirradiation (I.R) Studies of Prototypic Reactor Vessel Weldments," USNRC Report NUREG/CR-5469, Nov. 1989. 
50. J. R. Hawthorne and A. L. Hiser, "Investigations of Irradiation" Anneal-Reirradiation (IAR) Properties Trends of RPV Welds: Phase 2 Final Report," USNRC Report NUREG/CR-5492, Jan. 1990.

51. H. H. Hanninen and W. H. Cullen, "Slow Strain Rate Testing of a Cyclically Stabilized A-516 Gr. 70 Piping Steel in PWR Conditions," USNRC Report NUREG/CR-5327, Nov. 1989.

52. A. L. Hiser, "Fracture Toughness Characterization of Nuclear Piping Steels," USNRC Report NUREG/CR-5188, Nov. 1989.

53. J. R. Hawthorne and A. L. Hiser, "Influence of Fluence Rate on Radiation-Induced Mechanical Property Changes in Reactor Pressure Vessel Steels," USNRC Report NUREG/CR-5493, Mar. 1990.

54. A. L. Hiser, "Correlation of Irradiation-Induced Transition Temperature Increases from $\mathrm{C}_{\mathrm{v}}$ and $\mathrm{K}_{\mathrm{Jc}} / \mathrm{K}_{\mathrm{IC}}$ Data," USNRC Report NUREG/CR-5494, Mar. 1990. 
Prior reports dealing with the specific topic of this report are listed below:

1 J. R. Hawthorne and A. L. Hiser, "Experimental Assessments of Gundremmingen RPV Archive Material for Fluence Rate Effects Studies," USNRC Report NUREG/CR-5201, U. S. Nuclear Regulatory Commission, Washington, D. C., October 1988.

2. C. A. English, W. J. Phythian, J. T. Buswe11, J. R. Hawthorne, and P. H. Ray, "Investigations of Gundremmingen RPV Archive Material Irradiated in Light-Water and Heavy-Water Reactors," Effects of Radiation on Materials: 15th International Symposium, ASTM STP 11.25, R. E. Stoller, A. S. Kunar, and D. S. Gelles, Eds., American Society for Testing and Matorials, Philadelphia, PA, 1992, pp. 93-115. 
This investigation was part of the joint USA/FRG/UK program on postservice property investigations for the Gundremmingen KRB.A Reaclor Vessel.

The author thanks Dr. J. Fohl (MPA) for his personal efforts toward securing the Trepan $P$ specimens for the investigation and for the trepan reference condition data supplied. The author also expresses his appreciation to $\mathrm{J}$. W. Rogers (EG\&G Idaho, Inc.) for his personal effores on neutron dosimetry for the Experiment Assembly UBR-83A. He thanks $G$. Iohr and $H$, Sanders for thelr contributions in experiment construction, L. Schaffer for his efforts in postirradiation testing, and $W$. Comedy for her efforts in the preparation of this report. 


\section{INTRODUCTION}

The 250-MW bolling water Gundremingen Reactor, KRB-A, located in the Federal Republic of Germany (FRG) was decommissloned by the utility owners in 197?. Prior to its decommissioning, the resctor vessel operated at a nom nal temperature of $-288^{\circ} \mathrm{C}$ and had an inner wall fluence of about $3 \times 10^{18} \mathrm{n} / \mathrm{cm}^{2}$, $E>l \mathrm{MeV}$ (Ref, 1). In 1984, a remnant of a forging believed to be from the vessel construction was located by the $U$. $S$. Nuclear Regulatory Conmission (NRC). The avallability of this "archive" material and the service-degraded vessel material presented a unique opportunity for qualifying the effects of long-term irradiation on a prototypic reactor pressure vessel (RPV) steel. Specifically, the materials allowed direct testing of the effect of fluence rate (dose rate) on the degradation of Charpy $V\left(C_{v}\right)$ notch ductility and fracture toughness properties and the elevation of yield strength by neutron radiation. In addition, the materials permitted verification tests of present prediction methods for radiation-induced embrittlement (Ref. 2,3) and the attenuation of radiation effects through the vessel thickness (Ref. 2). The NRC subsequently put in place a foint USA/FRG program to (a) investigate the vessel's properties and (b) c nduct accelerated irradiation tests of the archive material for power. vs. test reactor comparisons. Materials Engineering Associates (MEA) and Material Pruefungsanstalt (MPA) were the lead laboratories for the two countries, respectively.

Qualification tests of the archive material located in storage at the General Electric Company provided evidence which, when coupled with vessel documentation, led to conclusions by MEA and MPA that (a) the base metal and Vessel Forglng No. 7.1 were from the same steel welt and (b) the base metal is representative of the vessel forging as flrst placed in service (Ref. 4). The materlal was in the form of two circumferentially-welded ring segments; the weld is suspected of belng a portion of the weld made for the reactor vessel survefllance program. One ring segment, approximately $119-\mathrm{mm}$ thick and weighing about $4450 \mathrm{~kg}$, was used for the primary MEA investigations of irradiation behavior. It is identifled in this report as the Code GEB material. The chemical composition of the GEB base material and that of the vessel's Forging Ring No. 7 are given in Table 1 and are identical for practical purposes. Composition test results for the base metal used in the reactor survelliance program also are indicated. The reactor surveillance program was in place at the commencement of inftlal commercial operations; however, only ASTM C-L orlentation base metal specimens (stcong orientation) were included in the survelllance capsules along with the weld metal and heat affected zone (HAZ) specimens. This was the recommendation of ASTM Practice $E 1.85$ in the early $1960^{\prime} \mathrm{s}$. 







\section{THE ANOMALY}

Tests of the irradiated trepan material by MPA and initial tests of UBR test reactor-irradiated archive material by MEA provided a major anomaly (Ref. 1,4). The archive material was in the form of ASTM L-C orientatipn (weak) $\mathrm{C}_{\mathrm{v}}$ specimens only; the specimens had been irradiated to $\sim 8.8 \times 10^{18}$ $\mathrm{n} / \mathrm{cm}^{2}, \mathrm{E}>1 \mathrm{MeV}$. at $288^{\circ} \mathrm{C}$. These exposure parameters reflect FRG best estimates of the vessel operating conditions and its end-of-Iife (EDL) exposure at program initiation in 1984. (Both parameters were later revised downward based on new information supplied to MPA.) As illustrated in Figure 1, the service-induced embrittlement appeared to be much greater than that produced by the UBR irradiation. Notice that the fluence to the trepan specimens (MPA determination) was approximately $2.4 \times 10^{18} \mathrm{n} / \mathrm{cm}^{2}$ or about onethird that received by the archive material. A second observation suggested by the data is that the trepan $\mathrm{C}-\mathrm{L}$ orientation suffered much less embrittlement than the L.C orientation. The cited L-C orientation vs. C-L orientation data comparison for relative induced-embrittlement, constitutes the anomalous behavior.

Prior experience in test reactor irradiation studies and the few $L-C$ vs. C-L orientation data comparisons available from RPV survelllance programs (both orientations contained in the same capsule) have led investigators to expect roughly-comparable elevations in 41-J transition temperature. Table 2, an excerpt from the NRC embrittlement data base (Ref. 5) 1ists many of the comparison data available from surveillance. A companion expectation is a greater "absolute" reduction in upper shelf energy level by that orientation having the higher preirradiation $C_{v}$ energy level, that is, the "strong" test orientation. The preirradiation difference must be pronounced for this observation. This is one reason that estimation procedures of NRC Regulatory Guide 1.99 for the upper shelf reduction is in terms of percentage decrease rather than an absolute change for a given fluence. A follow-on $288^{\circ} \mathrm{C}$ UBR irradiation of the archive material using both I.-C and C-L orientation specimens, removed from the $1 / 8 \mathrm{~T}$ thickness location, demonstrated that the GEB materidl conforms to both expectations (see Fig. 2, Ref. 4). The target fluence was $2.7 \times 10^{18} \mathrm{n} / \mathrm{cm}^{2}$ to better approximate the vessel inner wall $(1 / 8 \mathrm{~T})$ condition.

Mechanistic explanations are not in hand to account for the suggested difference in radiation sensitivity between test orientations. Embrittlement mechanisms identified from empirical data and experimental tests, in combination with theory by-in-large involve precipitation phenomena either enhanced or induced by irradiation (Ref, 6-10). Primarily the scenarios involve copper-rich precipitates or phosphorus-rich precipitates. A precipitation phenomenon would not explain the test orientation dependence (directionality) of radiation embrittlement sensitivity suggested by the KRB-A trepan data (Fig. 1). A radiation-induced weakening of the interface between MnS stringers and the matrix, on the other hand, would explain such a dependence. (Ref. 11).

1 F. Frisius, R. Kampmann, R. Wagner, and P. A. Beaven, "SANS Analysis of Irradiated and Unirradiated Fe Alloys Containing $\mathrm{Cu}, \mathrm{Ni}, \mathrm{P}$ : Final Report," MEA Report 2296, Materials Engineering Associates, Inc, Lanham, MD, March 1988. 



Fig. 1 Charpy-V notch ductility of KRB-A vessel material before and after irradiation service. Data from accelerated (test reactor) irradialons of the archive material by MEA and the Harwell Laboratory are indicated in the upper graph by the trend band; the dashed line in the lower graph shows the effect of long-term thermal conditioning (years) without irradiation (Ref. 1). 

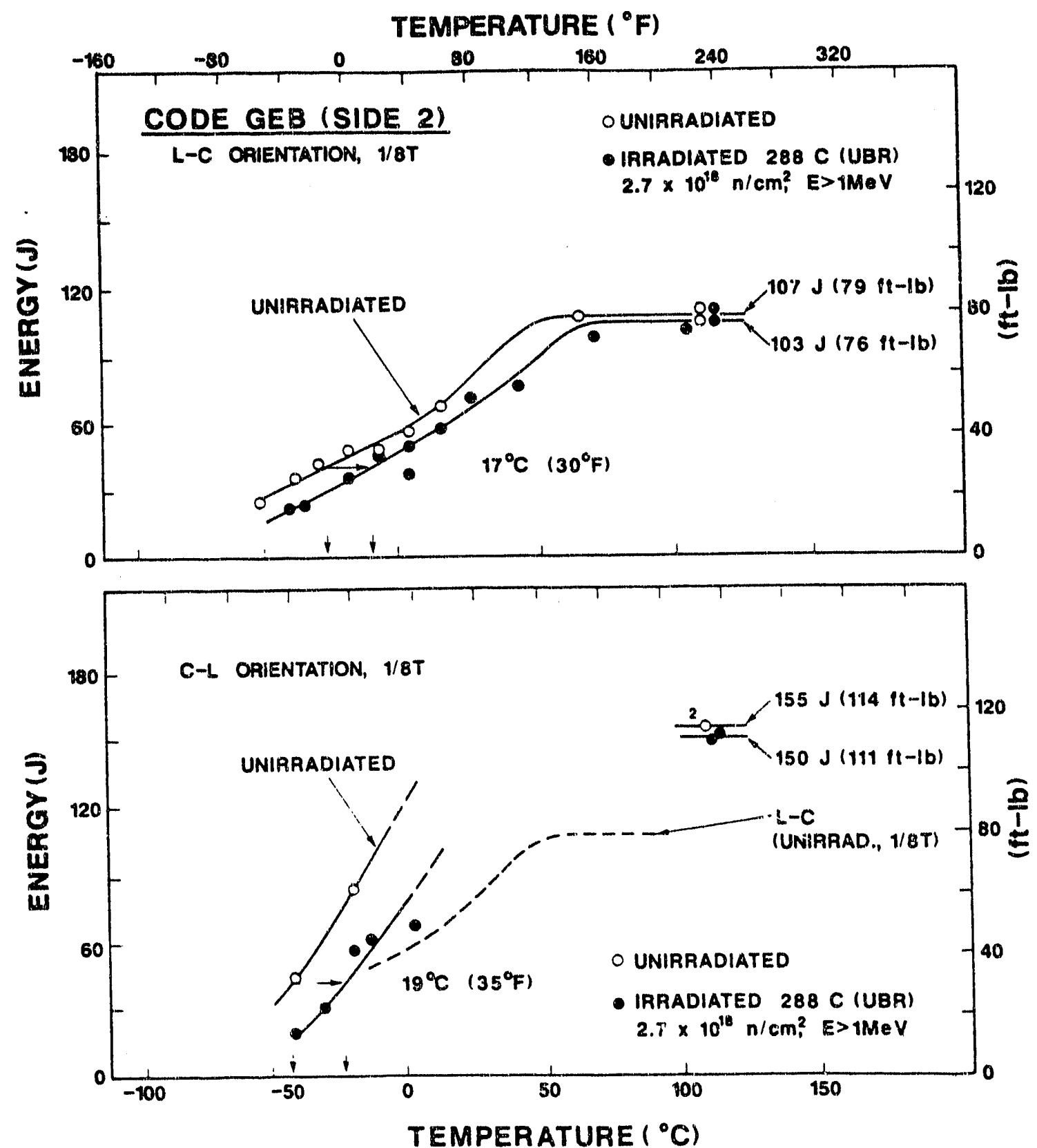

Fig. 2. Embrittlement of the archive material by a fluence matching that received by the KRB-A vessel in service (MEA Experiment Assembly UBR-78) (Ref. 4). 
Table 2 Comparison of LT vs. TL Orientation Embrittlement Data from RPV Surveillance (Ref. 5)

\begin{tabular}{|c|c|c|c|}
\hline \multirow[t]{2}{*}{ Entry } & \multicolumn{3}{|c|}{$C_{v}$ Upper Shelf Energy Reduction ${ }^{a}$ in $f t-1 b$} \\
\hline & LT Orientation & TL Orientation & Difference (LT-TL) \\
\hline 1 & 24 & 11 & 13 \\
\hline 2 & 14 & 25 & -11 \\
\hline 3 & 24 & 17 & 7 \\
\hline 4 & 35 & 2 & 33 \\
\hline 5 & 20 & 5 & 15 \\
\hline 6 & 19 & 3 & 16 \\
\hline 7 & 24 & 1.8 & 6 \\
\hline 8 & 30 & 8 & 22 \\
\hline 9 & 26 & 1.0 & 16 \\
\hline 10 & 12 & 0 & 12 \\
\hline 11 & 36 & 26 & 10 \\
\hline 12 & 28 & 119 & 9 \\
\hline 13 & 22 & 9 & 13 \\
\hline 14 & 33 & 22 & 11 \\
\hline 15 & 71 & 44 & 27 \\
\hline 16 & 40 & 12 & 28 \\
\hline 17 & 25 & 10 & 15 \\
\hline 18 & 0 & 13 & -13 \\
\hline 19 & 3 & -19 & 22 \\
\hline 20 & 22 & -6 & 28 \\
\hline 21 & 20 & 12 & 8 \\
\hline 22 & 25 & 13 & 12 \\
\hline 23 & 60 & 30 & 30 \\
\hline 24 & 43 & 18 & 25 \\
\hline 25 & 16 & 7 & 9 \\
\hline 26 & 14 & 13 & 1 \\
\hline 27 & 23 & 10 & 13 \\
\hline 28 & 17 & 15 & 2 \\
\hline 29 & 33 & 22 & 11 \\
\hline 30 & 15 & 2 & 13 \\
\hline 31 & 1.8 & 0 & 18 \\
\hline 32 & 24 & 14 & 10 \\
\hline 33 & 16 & 6 & 10 \\
\hline 34 & 4 & 11 & -7 \\
\hline 35 & 8 & 14 & -6 \\
\hline 36 & 14 & 8 & 6 \\
\hline
\end{tabular}

a Fluence range represented is $7.27 \times 10^{17}$ to $7.85 \times 10^{19} \mathrm{n} / \mathrm{cm}^{2}, \mathrm{E}>1 \mathrm{MeV}$. 
The directionality, if verified, could have a major impact on the application of Regulatory Guide 1.99 and the growing consideration of possible plant lifetime extensions (PLEX). To verify (or disprove) the anomaly, the present irradiation test was proposed. 


\section{APPROACH}

The approsch centered on the simultaneous irradiation of archive and trepan material specimens in one UDR assembly. The target irradiation temperature $\left(279^{\circ} \mathrm{C}\right)$ and the target fluence level $\left(2.6 \times 10^{18} \mathrm{n} / \mathrm{cm}^{2}\right)$ were intended to match, as closely as practical, those of the vessel trepans at their $1 / 8 \mathrm{~T}$ location. A kry aspect of the approach was the use of samples from outer layers of the trepans which had received a considerably lower fluence than the inner lay', 5 in prior service. The samples for the UBR assembly had received

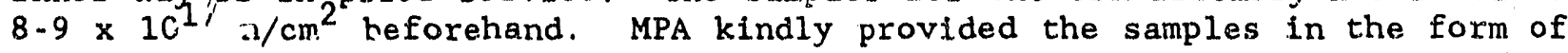
finish-machined $C_{v}$ specimens, under the fuspices of the continuing USA/FRG joint program. 


\subsection{Trepan Material}

The specimens for UBR-irradiation were cut from Trepan $P$ as illustrated in Figure 3. Layers 10 and 11 provided the samples for the L-C orientation assessments; Layers $8,9,10$ and 11 provided the samples for the C-L orientation assessments. The fluences received by the various layers from KRB-A service are listed in Table 3. Table 3 also gives the fluences recelved by these layers in the companion Trepans $C, D$ and $G$ from which samples were taken earlier for MPA's reference condition tests. In this report, the reference condition of Forging Ring No. 7.1 is that condition at the time of the $\mathrm{KRB}-\mathrm{A}$ decommissioning.

The diameter of the trepans was $107 \mathrm{~mm}$. The trepans were cut from the reactor vessel in a 3 (vertical) $\times 4$ (circumferential) array, at a location somewhat below the reactor mid-plane. Trepan $C$ and $D$ were in the row nearest the reactor mid-plane; Trepan $G$ was in the middle row; Trepan $P$ was in the row furthest from the mid-plane. The specimens were removed by electricaldischarge machining. The $V$-notch was produced by a milling machine cutter; no further machining was required.

\subsection{Archive Material}

$\mathrm{C}_{\mathrm{v}}$ samples and tension test samples were cut for both irradiation tests and check tests. The specimens were saw cut from the 1/8-T thickness layer indexed to the original inner diameter, that is, the as-forged surface. Samples for check tests of the unirradiated condition were taken from the same forging location as samples for the irradiation. As will be evident below, the check test data agree very well with the initial forging qualification data (Ref. 4). 


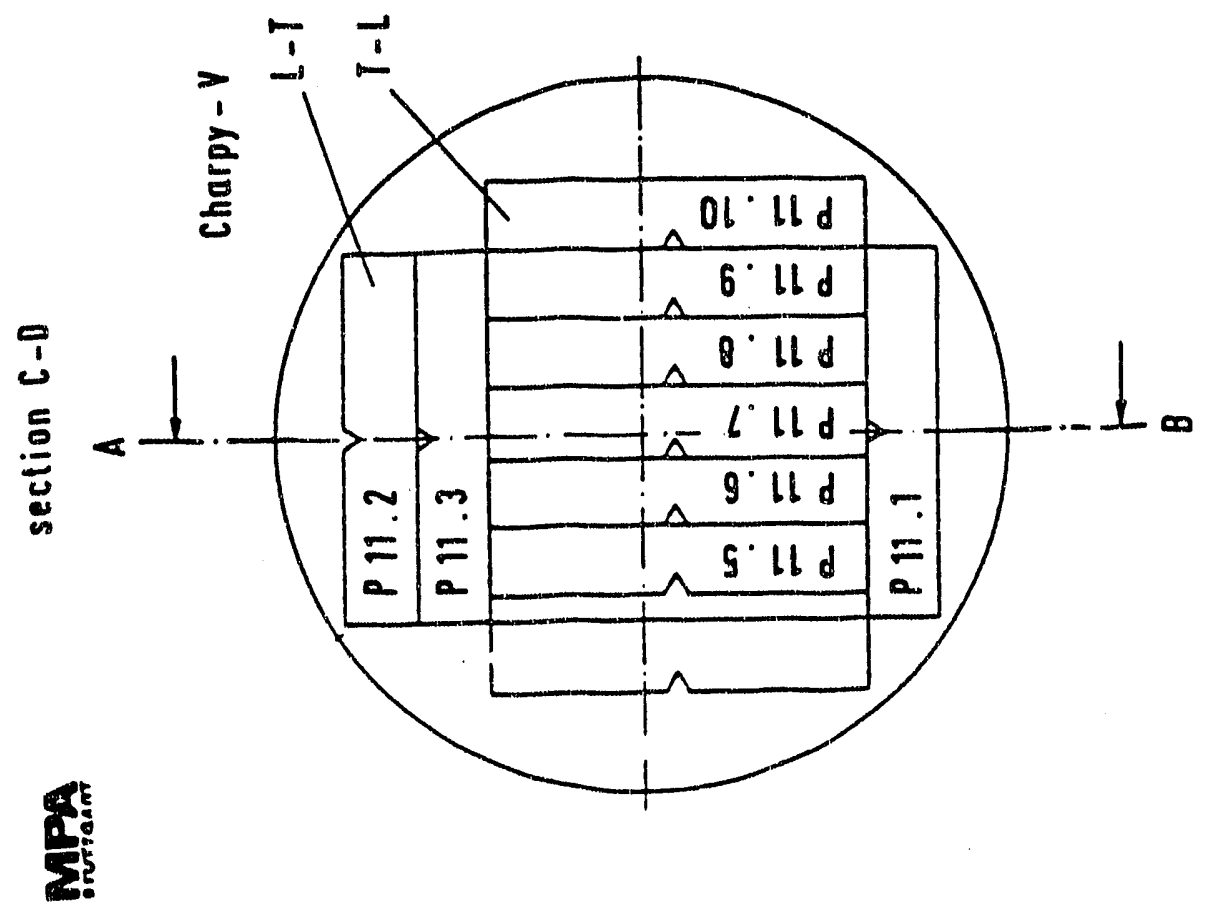

+1
0
2

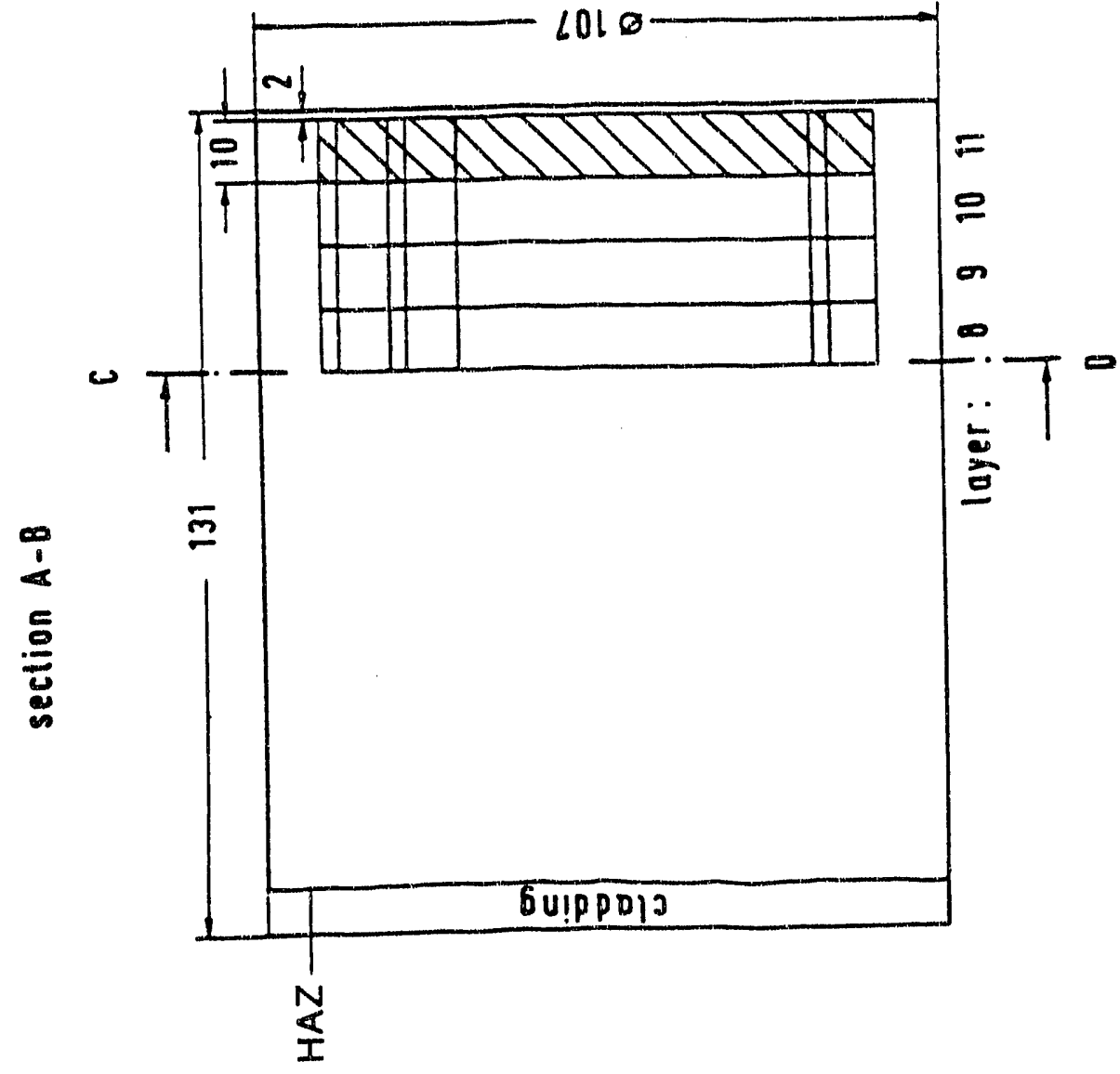

Di

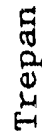

4
0
4

क्ष

م

是罗

出

3

E

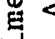

'

的蛋

$>\frac{1}{0}$

in

L. I.

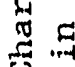

()

造

呚

资出

․

के

풍

出

马े

ن

4

E

点

$m$ 
Table 3 Neutron Fluences received by Specimen Layers 8 to 11 of Trepans P, C, $D$ and $G$ in KRB-A Service (Courtesy MPA)

\begin{tabular}{ccccc}
\hline $\begin{array}{l}\text { Specimen } \\
\text { Layer }\end{array}$ & \multicolumn{4}{c}{ Neutron Fluence $\left(\mathrm{n} / \mathrm{cm}^{2}, E>1 \mathrm{MeV}\right)$} \\
\cline { 2 - 5 } 8 & Trepan $\mathrm{P}^{\mathrm{a}}$ & Trepar & Trepan $\mathrm{D}$ & Trepan G \\
\hline 9 & 1.202 & 1.356 & 1.448 & 1.285 \\
10 & 1.047 & 1.179 & 1.261 & 1.118 \\
11 & 0.906 & 1.022 & 1.081 & 0.969 \\
\hline
\end{tabular}

a The UBR irradiation test involved L-C orentation samples from Layers 10 and 11 (only) and C-L orientation samples from Layers 8 to 11 of Trepan P. 


\section{MATERIAL IRRADIATION}

The specimens were irradiated in MEA Assembly UBR-83A in the UBR B-4 fuel lattice position. The fluence received was $2.6 \times 10^{18} \mathrm{n} / \mathrm{cm}^{2}, E>1 \mathrm{MeV}$. The irradiation time was 81.0 hours. Irradiation temperatures were monitored continuously with thermocouples welded to the specimen mid-lengths and were controlled externally by automatic instrumentation.

To preclude any exposure condition differences, the specimens of the two materials were randomized within the assembly. Specimen and thermocouple placements are documented in Figures 4 and 5, respectively. Iron, nickel, coppex and titanium dosimeter wires were placed within the specimen array and arranged over its length for fast neutron fluence $\left(\mathrm{n} / \mathrm{cm}^{2}, E>1 \mathrm{MeV}\right)$ and fluence-gradient determinations. Two ${ }^{238} \mathrm{U}$ neutron dosimeters were also placed within the specimen array. For thermal fluence determinations, Co-Al and AgAl dosimeter wires were used. Neutron dosimeter placements are indicated in F'igure 4.

Fluence values ( $\mathrm{E}>1 \mathrm{MeV}$ ) reported here are based on the calculated neutron energy spectrum for the irradiation facility ${ }^{2}$ (Ref. 12,13). The values can be converted to displacements per atom (dpa) exposure values by:

$$
\mathrm{dpa}=\text { calculated spectrum fluence, } \mathrm{E}>1 \mathrm{MeV}\left(1.47 \times 10^{-21}\right)
$$

Appendix A provides average fluence rates determined from individual neutrcn dosimeters. The UBR reactor operating history for Assembly UBR-83A is given in Appendix $B$.

The uncertainties in fluence rates from the iron, nickel and ${ }^{238} \mathrm{U}$ dosimetry are judged by the counting laboratory, EG\&G Idaho, Inc. to be $\pm 8, \pm 7$ and $\pm 5 \%$ for the $1 \sigma$ confidence level, respectively. These values do not include the uncertainties that would be associated with actual spectrum averaged crosssections of the irradiation fields or with burnout of the reaction products of interest. The uncertainty in cross-sections froin the neutron spectrum calculation is less than 158 .

Because the trepan specimens had a residual radioactivity from prior KRB-A service the irradiation assembly was final-fabricated on-site at the UBR which is located in the Buffalo Materials Research Center. A standard MEA irradiation assembly design nonetheless was used and standard MEA QA procedures were followed.

2 E. P. Lippincott, "Buffalo Light Water Reactor Calculation," Letter Communication Serial No. 7754977, Hanford Engineering Development Laboratory, P. O. Box 1970, Richland, WA 99352, to J. R. Hawthorne dated November 16, 1977. 


\begin{tabular}{|l|}
\hline UBR-83 \\
\hline$A-U N I T$ \\
\hline
\end{tabular}

$\left({ }^{238} U\right.$. MEA 55$) \longrightarrow$

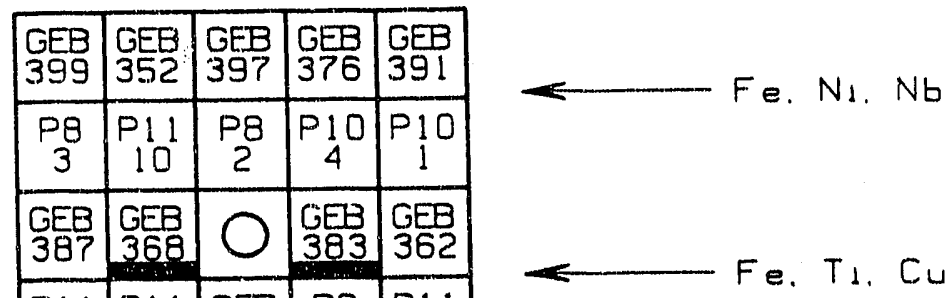

\begin{tabular}{|c|c|c|c|c|}
\hline 3 & 6 & 375 & 2 & 8 \\
\hline GEE & 0 & 0 & GEB & GEB \\
395 & & & 374 & 381 \\
\hline$P 10$ & $P 10$ & GEB & $P 11$ & $P 11$ \\
\hline
\end{tabular}

$\longleftarrow \mathrm{Fe}, \mathrm{T}_{1}, \mathrm{Cu}$

$\longleftarrow$ Fe. N

\begin{tabular}{|l|l|l|l|l|}
\hline GEB & GEB & $\bigcirc$ & GEB & GEB \\
364 & 379 & $\bigcirc$ & 385 & 355 \\
\hline
\end{tabular}

\begin{tabular}{|c|c|c|c|c|}
\hline$P 1 O$ & $P 9$ & GEB & $P 8$ & $P 10$ \\
6 & 354 & 1 & 10 \\
\hline$G E B$ & $G E B$ & $O$ & $G E B$ & $G E B$ \\
398 & 366 & & 358 & 389 \\
\hline$P 10$ & $P 9$ & $P 1 O$ & $P 11$ & $P 11$ \\
7 & 1 & 9 & 7 & 1 \\
\hline$G E B$ & GEE & GEB & GEE & GEB \\
360 & 393 & 378 & 401 & 372 \\
\hline
\end{tabular}

$\longleftarrow$ Fe. CoAl. AgA!

$\leftarrow-\mathrm{Ne}_{1}$

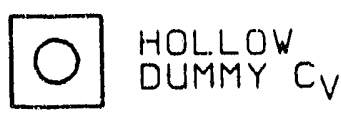

$c_{V}$

TENSIL.E

Fig. 4 Placement of Charpy $-V$ and tensile specimens in Irradiation Assembly UBR-83A (Elevation View). Locations of dosimeter wires and the location of the vial containing the ${ }^{238} \mathrm{U}$ dosimeter are also indicated. The wires span the five specimen-wide array and were placed in the $V$-notches of the Charpy specimens. 


\begin{tabular}{|l|}
\hline UBR-83 \\
\hline$A-U N I T$ \\
\hline
\end{tabular}


Fig. 5 Irradiation Assembly UBR-83A showing thermpcouple placements in the specimen array. 


\section{POSTIRRADIATION TESTING}

The $C_{y}$ specimens were broken on a $407-\mathrm{J}$ (300 ft-1b) capacity Tinius Olsen impact tester equipped with Dynatup instrumentation for recording applied load vs. time-of-fracture information during each test. The same machine was used by MEA for the irradiated, unirradiated and reference condition specimens. The machine was calibration-tested per ASTM Standard Method E 23 just before testing the present group of specimens ${ }^{3}$. Appendix $C$ provides the individual specimen data for the pre-UBR irradiation condition and the post-UBR Irradiated condition. Computer-curve fits of the data and values of curve fitting parameters are provided also. In the text data figures below, the brittle-ductile transition curves are visual best fits to the data.

3 R. Pasternak, Letter Report, U. S. Army Laboratory Command, Department of the Army, Watert wn, Ma 02172, to J. R. Hawthorne, May 26, 1989. 


\section{RESULTS}

\subsection{Archive Material}

Table 4 summarizes the results for the archive material and the trepan material. The $C_{v}$ test data for the former are illustrated in Fig. 6 . The transition temperature elevations for the L-C and C-L orientations were, respectively, $20^{\circ} \mathrm{C}\left(35^{\circ} \mathrm{F}\right)$ and $17^{\circ} \mathrm{C}\left(30^{\circ} \mathrm{F}\right)$. Fig. 7 compares the postirradiation data to that from the earlfer irradiation test (UBR-78) at $288^{\circ} \mathrm{C}$ to the same nominal fluence. Excellent agreement is observed. UBR irradiations of L-C orlentetion samples of GEB2 at $275^{\circ} \mathrm{C}$ and $288^{\circ} \mathrm{C}$ to a much higher fluence, $-8.6 \times 10^{18} \mathrm{n} / \mathrm{cm}^{2}$, revealed an essentially-nil sensitivity of the material to irradiution temperature differences in this range (Ref. 4). In turn, the excellent agreement of the data found in Fig. 7 confirms the high reproduceability of results from UBR irradiation tests. Only a slight difference in transition trend curve is discernable in the region between $\sim 75$ $\mathrm{J}$ (55 ft-lb) and the upper shelf regime. This may be simply a facet of the scatter pattern for the linited data available.

The observed reproduceability of postirradiation properties rules out the possibility (remote) that the anomaly under investigation is some manifestation of the UBR irradiation procedure or postirradiation test procedures. Good reproduceability of data with UBR irradiations has been shown by other RPV material studies (Ref. 14).

\subsection{Trepan Material}

The L-C and C-L orlentation data for the Trepan P material in Assembly UBR-83A are illustrated in Fig. 6. Postirradiation data trends for the archive material from Fig. 7 are also shown for comparison.

Initial inspection of the trepan data reveals no particular difference in postirradiation notch ductility due to thickness location in the trepan or the associated service-related fluence. The extent of data scatter is small; orily one postirradiation test point in each plot could be considered an outlier.

\subsection{Trepan vs. Archive Material}

The positions of the transition temperature curves for trepan vs, archive materials in Fig. 8 mirror the data which originally suggested an anomaly. The trepan curves fall to the right and below the archive material curves which could be construed as a manifestation of a material radiation sensitivity difference. Also, the transition temperature elevation and the upper shelf reduction for the trepan L-C orfentation is greater than those for the trepan C-L orientation. However, the indexing of the UBR-83A test results to the MPA data base for the reference condition, (tests of Trepans $C, G$ and D) presents a different picture (Fig. 9). Such indexing indicates transition temperature elevations of only $11^{\circ} \mathrm{C}$ and $14^{\circ} \mathrm{C}$ for the $\mathrm{L}-\mathrm{C}$ and $\mathrm{C}-\mathrm{L}$ orientations, respectively, not the elevations of $58^{\circ} \mathrm{C}\left(105^{\circ} \mathrm{F}\right)$ and $44^{\circ} \mathrm{C}\left(80^{\circ} \mathrm{F}\right)$ found when the data are indexed to the preirradiation properties of the archive material (Fig. 8). Likewise, the difference in upper shelf energy reduction is $5 \mathrm{~J}$, not $27 \mathrm{~J}$ for the L.C orientation. For the C-L orientation, an upper shelf reduction of $19 \mathrm{~J}$ is described by both inciexing methods. 


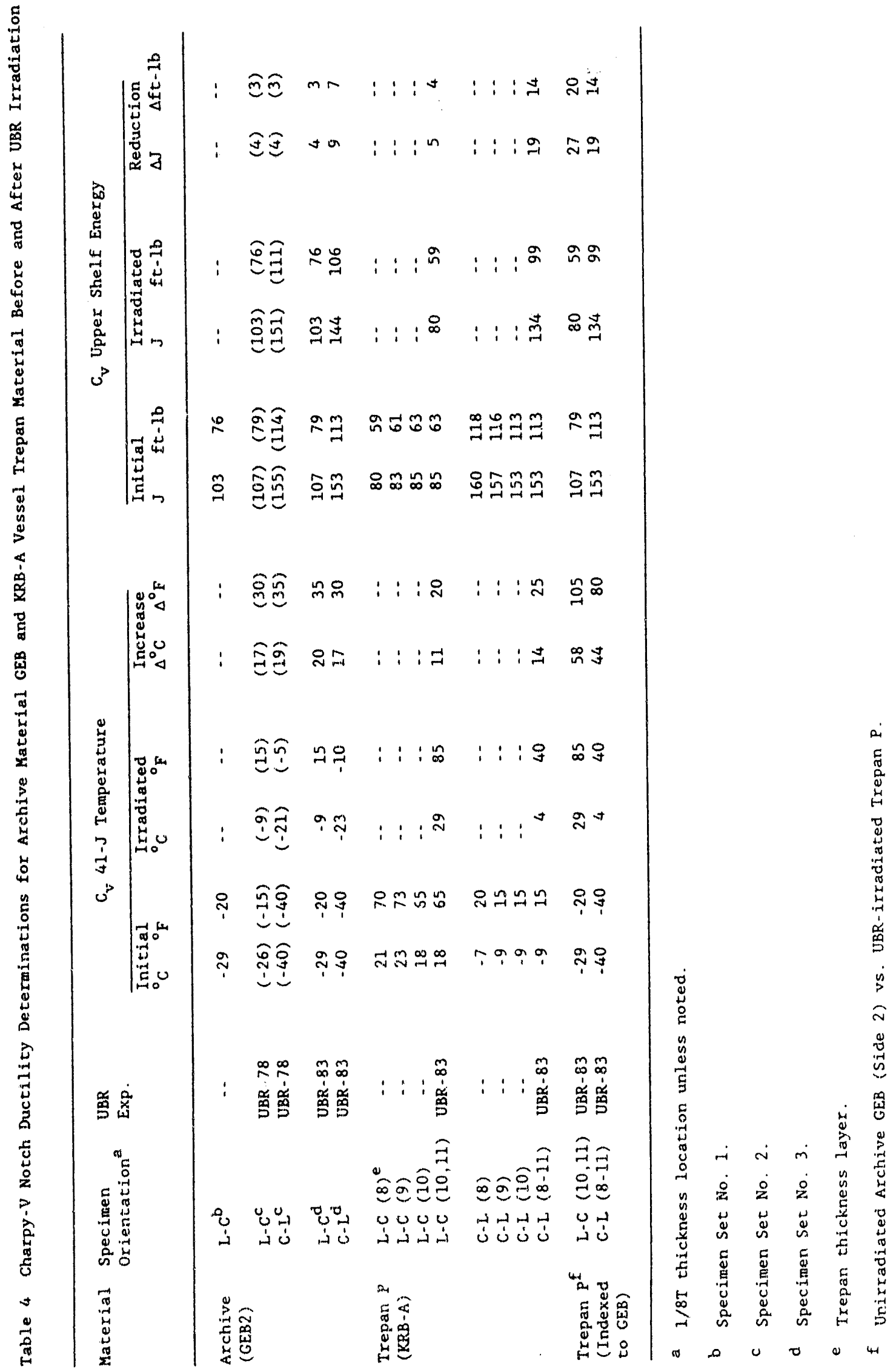



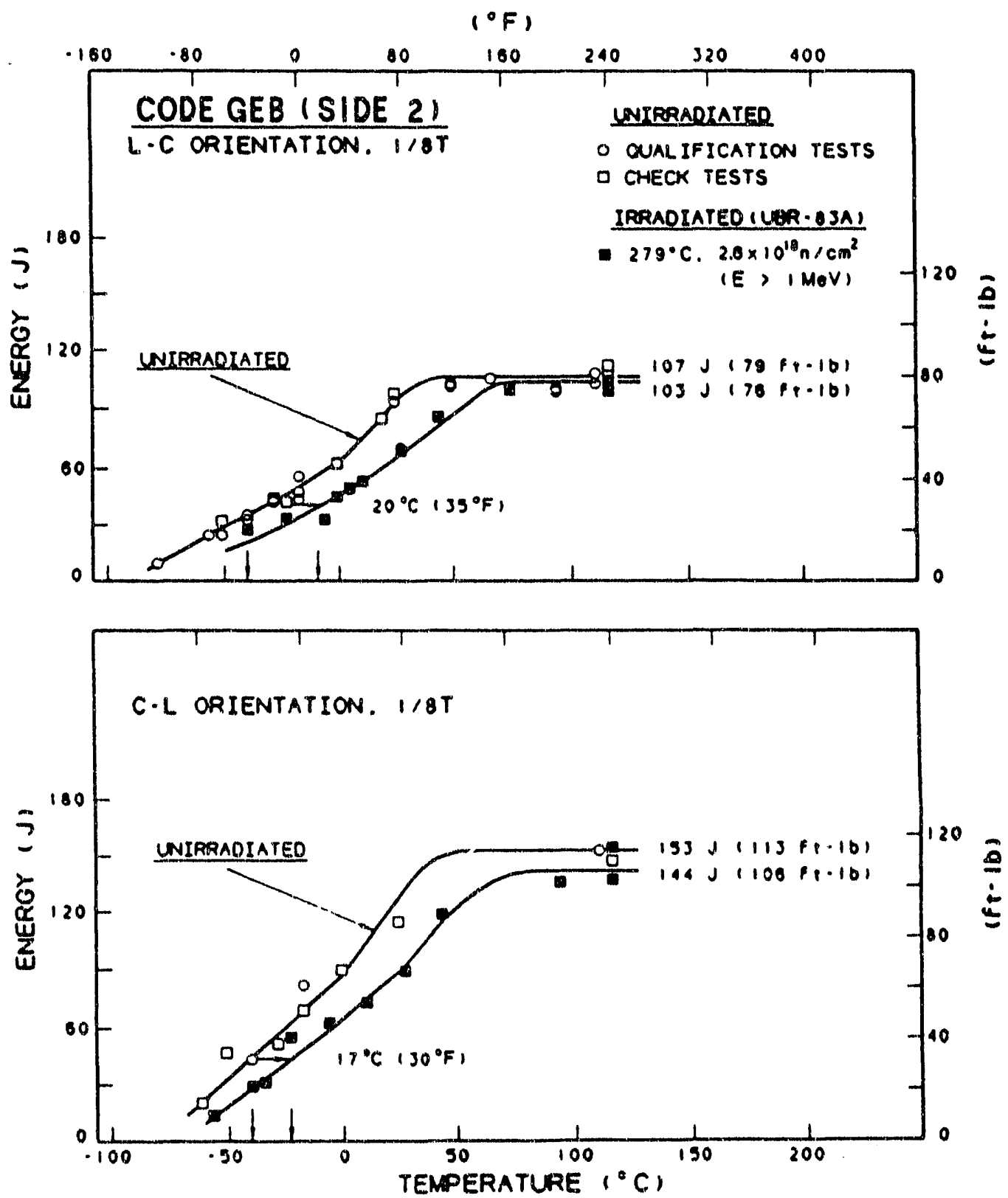

Fig. 6 Charpy-V notch ductility of the archive material before and after irradiation in Experiment Assembly UBR-83A. The unirradiated condition check test specimens and the specimens for irradiation were in close proximity to one another in the forging stock. 

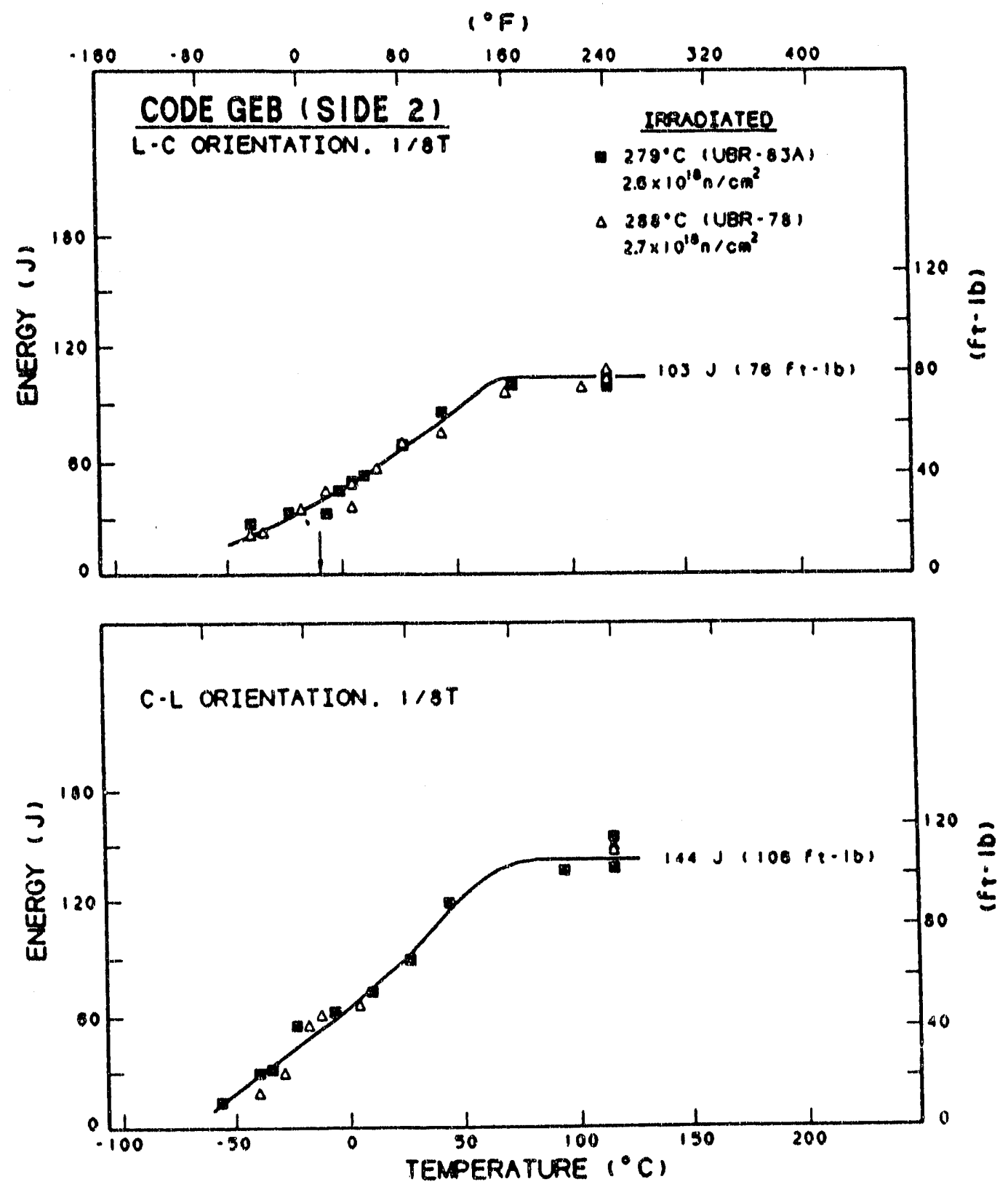

Fig. 7 Postirradiation Charpy-V data for the archive material from two UBR experiment assemblies showing the reproduceability of postirradiation properties. The irradiation temperature difference $\left(279^{\circ} \mathrm{C}\right.$ vs. $\left.288^{\circ} \mathrm{C}\right)$ was shown not significant by other tests. 

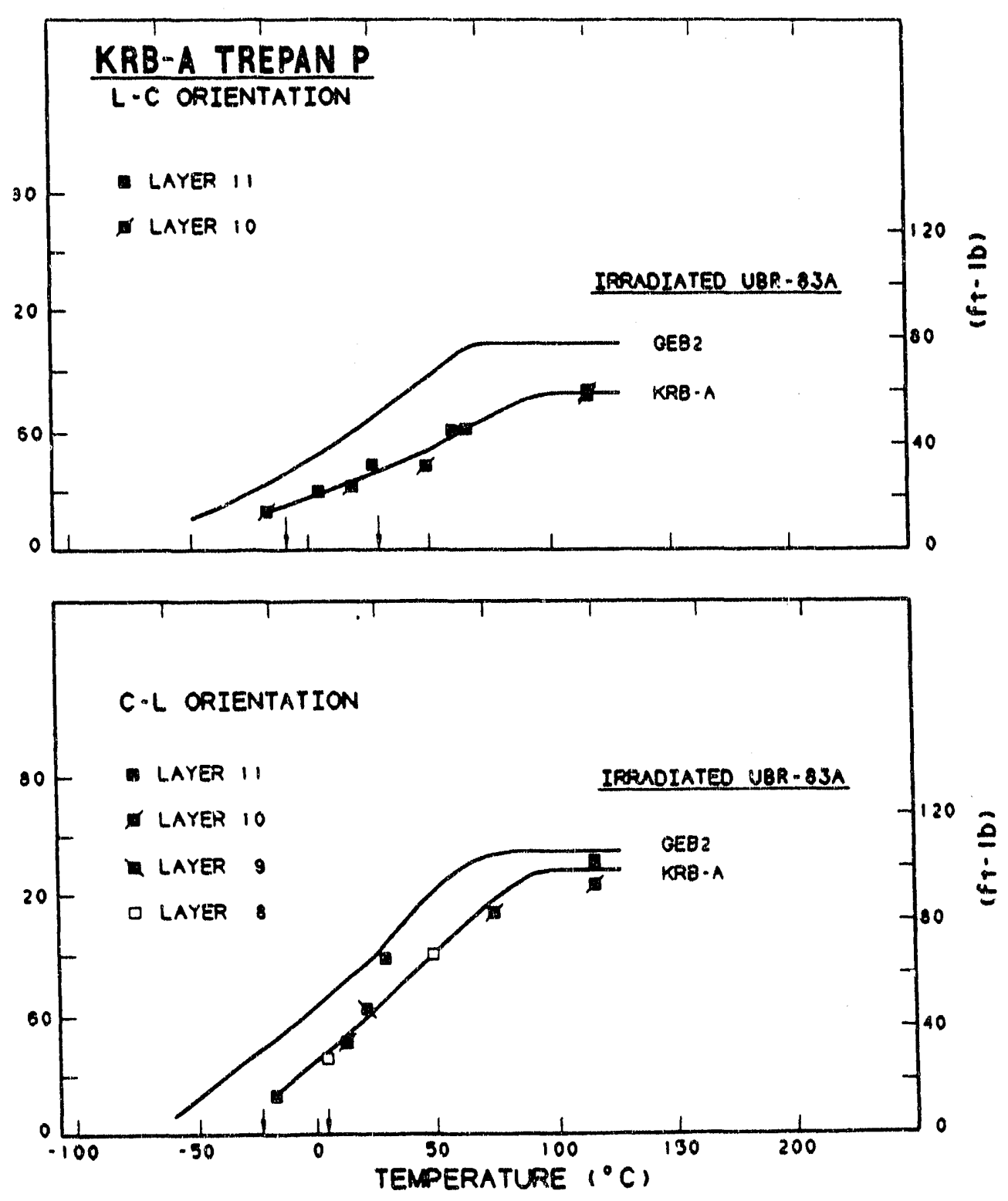

Fig. 8 Charpy-V notch ductility of the trepan material and the archive material after irradiation in Experiment Assembly UBR-83A. 

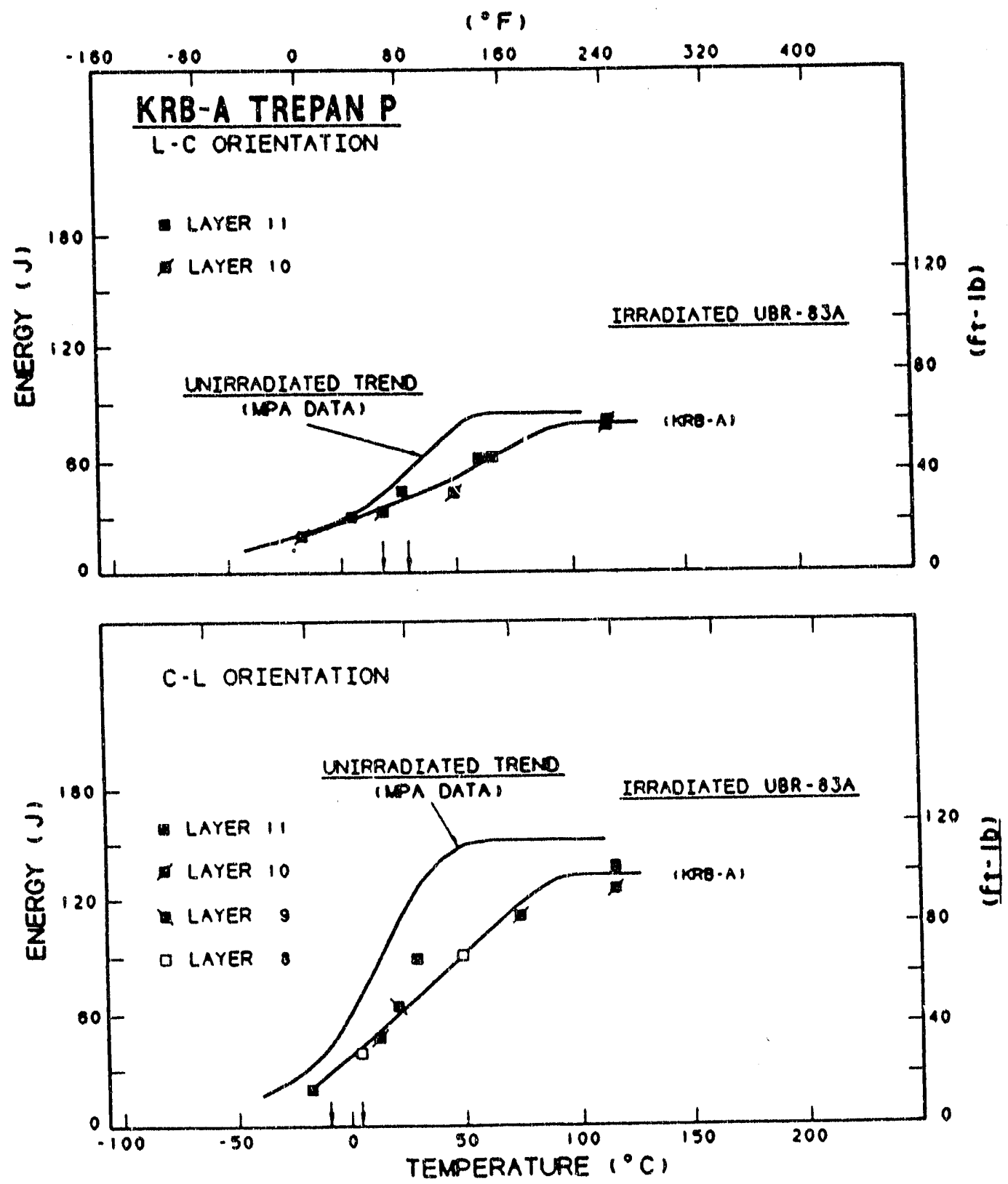

Fig. 9 Charpy-V notch ductility of the trepan material after irradiation in Experiment Assembly UBR-83A indexed to the post KRB-A service condition indicated by MPA test results. 
The $11^{\circ} \mathrm{C}$ and $14^{\circ} \mathrm{C}$ transition temperature elevations for the UBR frradiation of the trepan material agree well with the $20^{\circ} \mathrm{C}$ and $17^{\circ} \mathrm{C}$ transition temperature elevations found for the axchive material. (The $9^{\circ} \mathrm{C}$ difference for the L-C orientation is considered not significant.) The upper shelf energy reductions for the trepan material likewise agree well with those for the archive material. If the reasonable assumption is made that the properties of Trepan C, D and G represent well those of Trepan $P$, it can be concluded that the radiation embrittlement sensitivity of the trepan material, at least that of Layers 10 and 11 and quite possibly Layers 8 and 9 , is the same as that of the $1 / 8 \mathrm{~T}$ thickness location of the archive material for the acceleratedirradiation exposure case.

The difference in pre-UBR exposure properties of the trepan material vs. the archive material could stem from one or more of the following sources:

(1) Across-forging difference in unirradiated condition properties. The archive material represents one end of the forging while the trepan material depicts a location well-displaced (axlally and/or circumferentially) from the archive material locus in the forging.

(2) An undocumented difference in material heat treatments, particularly in stress relief heat treatment (s) after welding. It can be envisaged that the duration of the heat treatment of the archive weldment made for the surveillance program is quite different from that of the vessel's Forging Ring No, 7.1 as placed in service.

(3) The long time-at-temperature of the vessel (years) during its service iife. As noted in Figure 1, coupons of the archive material suspended in the vessel well away from the fuel core did show a significant change in transition temperature for the C-L orientation due to a temperature effect alone. The archive material was not similarly aged.

(4) Contrary to the extensive evidence and archive material markings, the archive material was not from the same steel melt as the vessel's Forging Ring No. 7.1 .

(5) Some aspect of trepan removel, specimen blanking or specimen machining altered the properties of the material.

The above possibilities are reviewed in the Discussion section below relative to their potential impact on Regulatory Guide 1.99 applications and RPV surveillance programs. It is MEA's opinion that the first and third possibilities are the strongest in this case. Again, it is stated that the apparent radiation sensitivities of the two materials shown in the UBR irradiation were the same. Accordingly, the anomaly cannot be ascribed to some basic difference in material resistance to a $279^{\circ} \mathrm{C}$ nuclear environment.

7.4 Trepan Data (Inner Wall vs. Outer Wall Layers - Preservice Condition)

The MPA daca for Layers 8 to 10 of Trepans $C, D$ and $G$ are illustrated in Figure 10. Listings of these data are included in Appendix C. Plotting the data by individual layers, 41-J transition temperatures and upper shelf levels could be established. Superposition of the curves showed very little throughthickness differences in either property. In tests of the archive material, a 

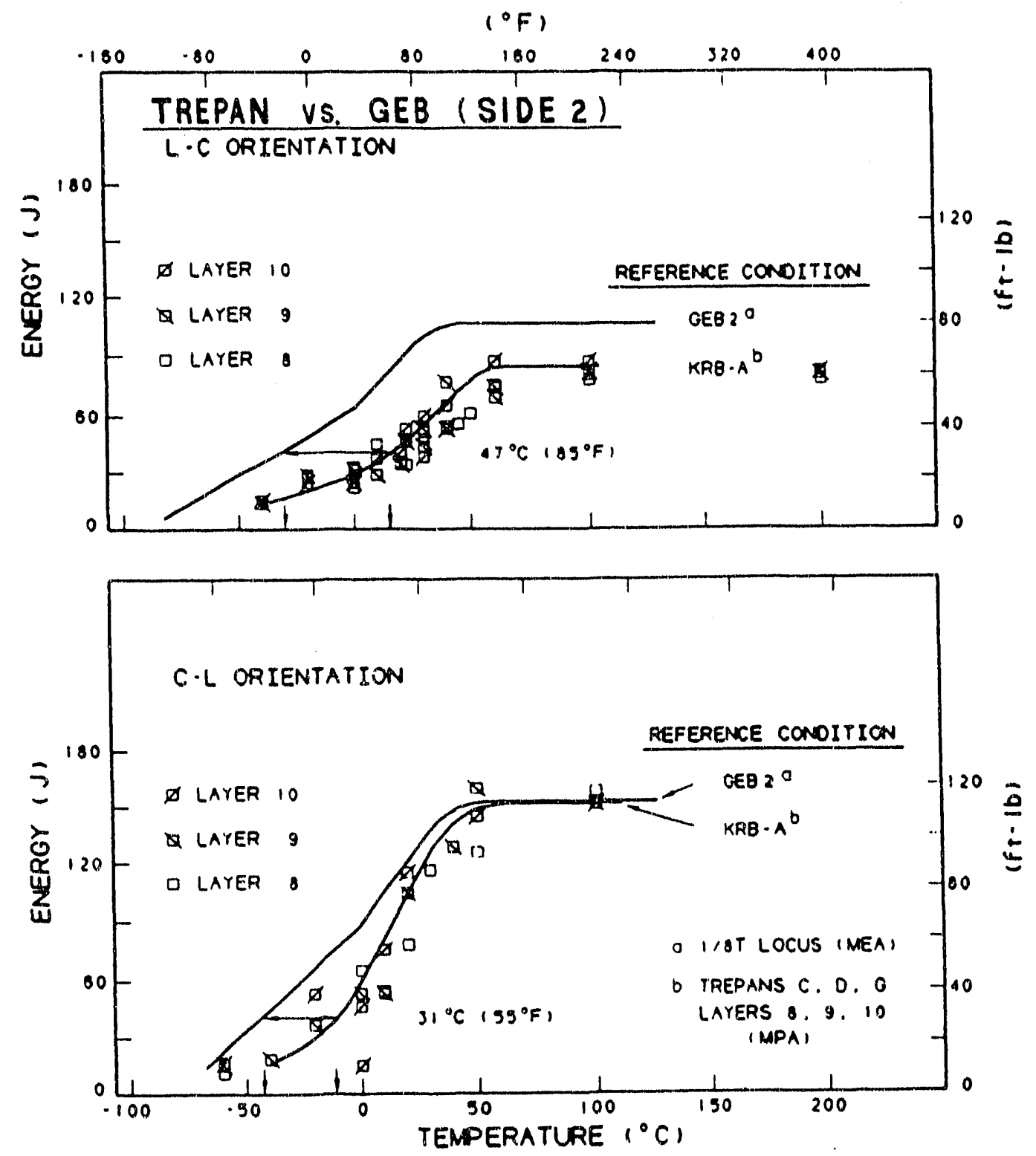

Fig. 10 Vomparison of the notch ductility of the trepan material and the archive material before irradiation in the UBR. Notice the agreement of data for thr three trepan layers; the trend curves are based on Luyer 9 and 10 data primarily. 
good correspondence of $1 / 4 \mathrm{~T}$, vs, $1 / 8 \mathrm{~T}$ and $7 / 8 \mathrm{~T}$ thickness location upper shelf properties was also observed. Only a small difference in $41-\mathrm{J}$ temperature $\left(11^{\circ} \mathrm{C}\right)$ was noted for $1 / 4 \mathrm{~T}$ vs. $1 / 8 \mathrm{~T}$ (or $7 / 8 \mathrm{~T}$ thickness) locations. With this evidence, it is assumed here for discussion purposes that the $1 / 8 \mathrm{~T}$ and $7 / 8 \mathrm{~T}$ properties of the vessel as placed in service were the same.

\subsection{Trepan Data (Inner Wall-Postservice vs. Outer Wall-UBR Irradiated)}

Figure 11 compares the data for the UBR irradiation of the trepan (outer wal1) to the data for the service-irradiated trepan (inner wa11). Referring to the lower graph for the C-L orientation and temporarily ignoring the shapes of the curves, one observes that the upper shelf energy levels (and the $41-\mathrm{J}$ transition temperatures) are about the same. This correspondence suggests no fluence-rate effect between the two reactors (KRB-A vs. UBR).

In contrast, the L-C orientation data yield two curves that are in general agreement up to an energy absorption level of about $61 \mathrm{~J}$ (45 $\mathrm{ft}$-1b) but diverge above this level, that is, above $71^{\circ} \mathrm{C}\left(160^{\circ} \mathrm{F}\right)$. At $71^{\circ} \mathrm{C}\left(160^{\circ} \mathrm{F}\right)$, both the C-I orientation curve and the L-C orientation curve for the UBR irradiation of the trepan specinens have a positive slope. The curves do not show an onset of upper shelf behavior until about $104^{\circ} \mathrm{C}\left(220^{\circ} \mathrm{F}\right)$. The onset of upper shelf behavior for the UBR-irradiated outer-wall material at $104^{\circ} \mathrm{C}$ vs. much lower temperatures for the service-irradiated inner-wall material in spite of the similarity in $41-\mathrm{J}$ temperatures, is in itself an anomaly.

Of further puzzlement is the relative positions and shapes of the KRB-A service-irradiated inner-wall material vs. outer-wall material in the transition region ( $C-L$ orientation). The lower portion of the curve for the inner-wall material lies slightly to the right of that for the outer-wall material (expected relationship), but the upper portion of the curve for the inner-wall materlal lies well to the left of that for the outer-wall material signifying better notch ductility and less radiation-induced embrittlement (unexpected). For the outer-wall material, since both orientations in the service-irradiated condition and the UBR-irradiated condition describe an internaliy-consistent family of curves, it can be concluded that they are reasonably accurate depictions of the properties. (A change in slope of curves by irradiation has been observed with other materials.) Ar explanation for the particular shape of the transition curve for the inner-wall material cannot be offered at this time. While both Txepan $C$ and $G$ supplied inner-wall location specimens for development of this curve, no pronounced properties difference due to sample location was reported by MPA (Ref. 1).

Of the two unusual data patterns cited above, the pattern of most concern is the difference in postirradiation upper shelf levels for the L-C orientation. Two observations may provide a clue. The upper shelf energy decreases for the inner-wall location indexed to the outer-wall location (postservice condition) are essentially the same, that is, $26 \mathrm{~J}(\mathrm{C}-\mathrm{L}$ ) and $23 \mathrm{~J}$ (L-C). Secondly, it is observed that the upper shelf levels for the C-L orientation and L-C orientation commence at roughly $16^{\circ} \mathrm{C}$ and $77^{\circ} \mathrm{C}$, respectively. A mechanistic explanation for this large temperature difference is absent. 

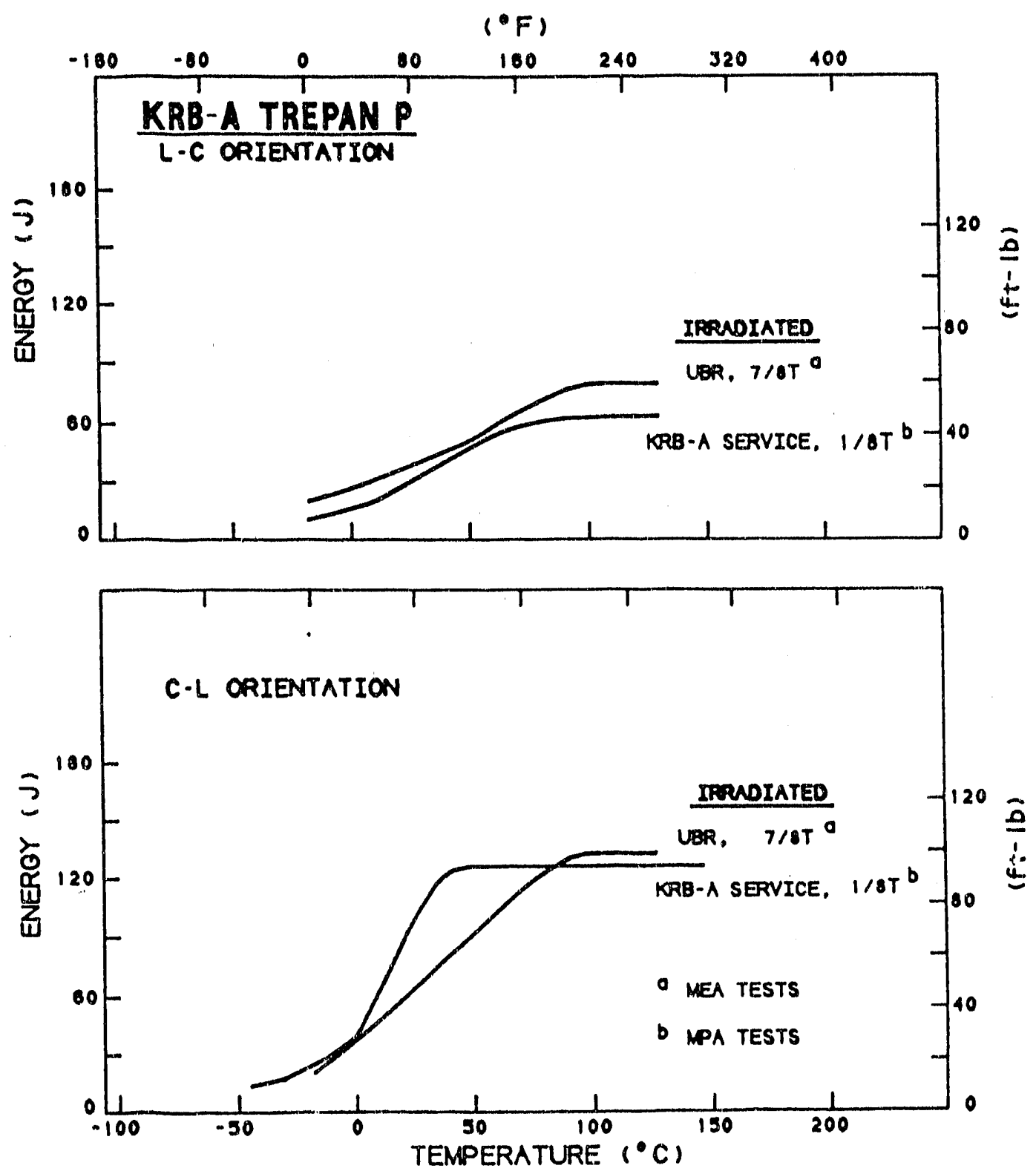

Fig. 11 Charpy-V notch ductility of the trepan material after KRB-A service irradiation (inner-wall location) and after the UBR accelerated irradiation (outer-wall location). Good agreement in upper shelf energy level is observed for the C-L orientation data but not the L-C orientation data. 
The present investigation has proven that the initially-reported anomaly (Ref. 1,4) is not due to a basic difference in radiation-embrittlement sensitivity between the test materials. That is, the archive GEB material and the Trepan $P$ material (outer-wall layers) exhibited comparable embrittlement after simultaneous irradiation in the UBR test reactor.

A large difference in notch ductility between the archive material (preirradiation condition) vs. the trepan material (post-service reference condition, outer-wall layer) is apparent with one exception: the C-L orientations of these materials have about the same upper shelf energy level. Analyses of the data provide the following concerns. If the "cause" of the overall difference in reference properties is due to the difference in forging locations represented by the materials and not to a low fluence effect and/or a thermal aging effect, the implication is one of a general problem for forgings and their sampling. In this scenario, the archive material selected for surveillance may not be providing the worst-case properties for the vessel material and in fact, may lead to underestimates of the actual $41-\mathrm{J}$ tempexature and overestimates of the actual upper shelf energy level by significant margins. Conversely, if the cause is the low level fluence exposure of the outerwall layer and not some across-forging variability, the 31 to $47^{\circ} \mathrm{C}$ difference in $41-\mathrm{J}$ temperature suggests that we have not been attaching proper significance to the effects of this fluence regime. Thirdly, it could be that long-term thermal aging effects likewise have been underestimated. Fortunately, the second and third scenarios do not impact the validity of surveillance capsule data except for the possibility of large disparities between surveillance capsule time-at-temperatures and vessel wall time-at-temperatures. With a 3:1 lead factor, for example, a surveillance capsule might have only 3 years at temperature vs. a 9 year time at temperature for the vessel. Little is known about time-at-temperature effects for those very long periods of time equated to RPV design lifetimes and PLEX operations.

The comparison made of UBR-irradiated trepan material (outer wall layers) vs. the service-irradiated trepan material (inner wall layers) has reduced the scope of the original anomaly to the question of the low upper shelf energy level of the L-C orientation. The possibility of the anomaly being the result of some heretofore unobserved dose rate effect that is test-orientation dependent, cannot be dismissed on the basis of the latest UBR irradiation comparison of the archive vs. trepan materials. The outer wall layer of the vessel material and the archive material describe higher upper shelf energy levels after UBR irradiation.

The answer may reside in the seeming inconsistencies in the trepan inner-wall notch ductility properties relative to outer-wall properties, for example, the large disparity in upper shelf level between $1 / 8 \mathrm{~T}$ and $7 / 8 \mathrm{~T}$ locations for the L-C but not the C-L orientation. It is believed that the explanation will not be found simply though additional mechanical property testing. Instead, the trepan and archive materials should be examined with state-of-the-art microscopy focusing on those aspects governing upper shelf energy absorption. To help expedite resolution, the materials have been offered to the International Group on Radiation Damage Mechanisms in Pressure Vessel Steels (IG-RDM). Mechanisms identification is important to better understand and project in-service embrittlement behavior and PLEX capabilities (Ref. 15). 


\section{CONCLUSIONS}

The findings from the simultaneous test reactor irradiation of the trepan material from the Gundremmingen $\mathrm{KRB}-\mathrm{A}$ reactor vessel and the archive material has greatly reduced the uncertainties regarding the cause(s) of the originally reported anomalous property differences between the materials in the postirradiation condition. The important observations and determinations from this investigation can be enumerated:

(1) The UBR irradiation at $279^{\circ} \mathrm{C}$ produced $41-\mathrm{J}$ transition temperature elevations of $11^{\circ} \mathrm{C}$ and $14^{\circ} \mathrm{C}$ for the trepan material (L-C and $\mathrm{C}-\mathrm{L}$ orientation, respectively) vs. $20^{\circ} \mathrm{C}$ and $17^{\circ} \mathrm{C}$ for the archive material.

(2) The UBR irradiation at $279^{\circ} \mathrm{C}$ produced upper shelf energy reductions of $5 \mathrm{~J}$ and $19 \mathrm{~J}$ for the trepan material (L-C and C-L orientation, respectively) vs. $4 \mathrm{~J}$ and $9 \mathrm{~J}$ for the archive material.

(3) From (1) and (2), the radiation embrittlement sensitivities of the trepan material (outer wall region) and the archive material (1/8T region) are essentially the same. This proves that the originallyobserved differences are not due to a basic difference between material radiation resistances.

(4) The pre-UBR irradiation $C_{v}$ properties of the trepan and archive materials are not the same. For the L-C orientation, the $41-\mathrm{J}$ temperature of the trepan material was $47^{\circ} \mathrm{C}\left(85^{\circ} \mathrm{F}\right)$ higher and the upper shelf energy level was $22 \mathrm{~J}$ (1.6 ft-1b) lower than those of the archive material. For the C-L orientation, the $41-\mathrm{J}$ temperature of the trepan material was $31^{\circ} \mathrm{C}\left(55^{\circ} \mathrm{F}\right)$ higher than that for the archive material but the upper shelf energy levels were the same $-153 \mathrm{~J}(113 \mathrm{ft}-\mathrm{lb})$.

(5) More than one cause may be responsible for the differences in preirradiation properties cited in (4).

(6) The properties dissimilarities in (4) would explain some (but not al1) of the apparently greater radiation embrittlement found for the trepan material (inner wall, L-C orientation) compared to UBR-irradiated archive material.

(7) For both L-C and C-L orientations, the 41-J transition temperatures of the service-irradiated trepan material (inner wall) and the UBRirradiated trepan material (outer wall) are about the same, illustrating ar. absence of a fluence rate effect on this property.

(8) The upper shalf energy levels of the service-irradiated trepan material (inner wall) and the UBR-irradiated trepan material (outer wall) are about the same in the C-L orientation (strong) but differ greatly in the L-C orientation (weak).

(9) Proven metallurgical or mechanistic explanations for the L-C orientation difference of (8) are not yet available. Seeming inconsistent notch ductility relationships which may constitute clues to the remaining anomalous data indications, are identified. 


\section{REFERENCES}

1. K. Kussmaul, $J$. Fohl and $I$. Weissenberg, "Assurance of the Pressure Vessel Integrity with Respect to Irradiation Embrittlement - Activities in The Federal Republic of Germany (FRG)," Proceedings NEA/CSNI-UNIPEDE Spectalist Meeting on Regulatory and Life-Limiting Aspects of Core Internals and Pressure Vessels, CSNI Report No. 146, pp.489.538, September 1988.

2. "Radiation Embrittlement of Reactor Vessel Materials," USNRC Regulatory Guide 1.99, Rev. 2, U. S. Nuclear Regulatory Commission, Washington, DC, May 1988.

3. "Standard Gulde for Predicting Neutron Radiation Damage to Reactor Vessel Materials," E 900-87, Book of ASTM Standards, American Society for Testing and Materials, Philadelphia, PA, Volume 12.02, pp. 689-695, 1987.

4. J. R. Hawthorne and A. L. Hiser, "Experimental Assessments of Gundremungen RPV Archive Material for Fluence Rate Effects Studies," USNRC Report NUREG/CR-5201, U. S. Nuclear Regulatory Commission, Washington, DC, October 1.988.

5. F. W. Stallmann, C. A. Baldwin, F. B. K. Kam and B. J. Taylor, "Description of the Power Reactor Embrittlement Data Base Rev. 1," USNRC Report NUREG/CR-4816 Rev, 1, Nuclear Regulatory Commission, Washington, DC, May 1991.

6. M. K. Miller, M. G. Hetherington, and M. G. Burke, "Atom Field Ion Microscopy: A Technique for Microstructural Characterization of Irradiated Materials on the Atom Scals," presented at the TMS/ASM Fall Meeting, Chicago, IL, September 1988.

7. M. G. Burke and M. K. Miller, "Solute Clustering and Precipitation in Pressure Vessel Steels under Low Fluence Irradiation Conditions," Journal de Physlque, Vol. 49-C6, pp. 283-288, November 1988.

8. P. A. Beaven, F. Frisius, R. Kampmann, R. Wagner, and J, R. Hawthorne, "SANS Livestigation of Irradiated A 533-B Steels doped with Phosphorus," Radiation Embrittlement of Nuclear Reactor Fressure Vessel Steels: An International Revilw, 3rd Volume, ASTM STP 1011, American Soclety for Testing and Materials, Philadelphia, PA, Pp. 243-256, 1989.

9. M. Valo, H. Huomo, P. Nyberg, and P. Hautojarvi, "Positron Lifetime Characterization of Irradiated Pressure Vessel Model Alloys," Radiation Embrittlement of Nuclear Reactor Pressure Vessel Steels: An International Review, 3rd Volume, ASTM STF 1011, American Society for Testing and Materials, Philadelphia, PA, Pp. 257-261, 1989.

10. G. R. Odette and G. E. Lucas, "Irradiation Embrittlement of Reactor Pressure Vessel Steels: Mechanisms and Models and Data Correlations," Radiation Embrittlement of Reactor Pressure Vessel Steels, ASTM STP 909, Avierican Soclety for Testing and Materials, Philadelphia, PA, Pp. 206, 1986. 
11. C. A. English, W. J. Phythian, J. T. Buswel1, J. R. Hawthorne, and P. H. Ray, "Investigations of Gundremmingen RPV Archive Material Irradiated in Light-Water and Heavy-Water Reactors," Effects of Radiation on Materials: 15th International Symposium, ASTM STP 1125, R. E. Stoller, A. S. Kumar, and D. S. Gelles, Eds., American Society for Testing and Materials, Philadelphia, PA, 1992, pp. 93-115.

12. E. P. Lippincott, L. S. Kellogg, W. N. McElroy, and C. A. Baldwin, "Evaluation of Neutron Exposure Conditions for the Buffalo Reactor," Proceedings of the Fifth International ASTM-Euratom Symposium, Geesthacht, Federal Repub1ic of Gexmany, September 24-28, 1984.

13. G. Prillinger, E. D. McGarry, and J. R. Hawthorne, "Neutron Spectra Calculations for Ex-Core Irradiation Experiments at the Buffalo Reactor," Proceedings of the ASTM Fourteenth International Symposium on Effects of Radiation on Material, Andover, MA, June 27-30, 1988.

14. J. R. Hawthorne, "An Exploratory Study of Element Interactions and Composition Dependencies in Radiation Sensitivity Development: Final Report," USNRC Report NUREG/CR-5357, Nuclear Regulatory Commission, Washington, DC, April 1989.

15. J. R. Hawthorne, "Mechanisms of Irradiation Damage for Reactor Vessel Steels," Compilation of Contract Research for the Materials Engineering Branch, Division of Engineering - Annual Report for FY 1988, U. S. Nucleax Regulatory Commission, NUREG.0975, Vo1. 7, pp. 82.84, April 1989. 


\section{APPENDYX A}

Neutron Dosimetry Determinations Based on Fission Spectrum Assumption for Irradiation Experiment UBR-83A 
Table A-1 Irradiation Assembly UBR-83A Fluence-Rate Monitor Results (Ref, A.1)

\begin{tabular}{|c|c|c|}
\hline Monitor/Segment & $\begin{array}{c}\text { Fluence Rate } \\
\text { (average) }\end{array}$ & $\begin{array}{l}\text { Monitor Location in } \\
\text { Specimen Array }\end{array}$ \\
\hline $\begin{array}{r}\mathrm{A} 8(\mathrm{Fe}) \\
(\mathrm{NI})\end{array}$ & $\begin{array}{l}6.15 \\
6.44\end{array}$ & Between layers 1 and 2 \\
\hline $\begin{array}{r}\text { Al }(\mathrm{Fe}) \\
(\mathrm{T} 1) \\
(\mathrm{Cu})\end{array}$ & $\begin{array}{l}6.20 \\
5.64 \\
5.24\end{array}$ & Between layers 3 and 4 \\
\hline $\begin{aligned} A 7 & (\mathrm{Fe}) \\
& (\mathrm{Ni})\end{aligned}$ & $\begin{array}{l}6.28 \\
6.62\end{array}$ & Between layers 6 and 7 \\
\hline Al1 $\begin{aligned} & (\mathrm{Fe}) \\
& (\mathrm{Co}-\mathrm{Ag})\end{aligned}$ & $\begin{array}{l}6.47 \\
2.99^{c}\end{array}$ & Between layers 8 and 9 \\
\hline $\begin{aligned} \mathrm{A} 4 & (\mathrm{Fe}) \\
& (\mathrm{Ni})\end{aligned}$ & $\begin{array}{l}6.47 \\
6.85\end{array}$ & Between layers 10 and 1 \\
\hline $\begin{array}{c}\text { Vial }\left({ }^{238} \mathrm{U}\right) \\
(\mathrm{Fe}) \\
(\mathrm{Ni})\end{array}$ & $\begin{array}{l}7.93^{\mathrm{d}} \\
(9.04)^{\mathrm{e}} \\
6.34 \\
6.61\end{array}$ & At layer 5 \\
\hline
\end{tabular}

a See Fig. 4 in main text for monitor loci. The Fe, Ni and ${ }^{238} \mathrm{U}$ results are based on $>1 \mathrm{MeV} 238 \mathrm{U}$ fission spectrum averaged cross sections of $115.2,156.8$ and 441 millibarns, respectively.

b Fission spectrum assumption; $\mathrm{n} / \mathrm{cm}^{2}-\mathrm{s}^{-1}$ ( $\mathrm{E}>1 \mathrm{MeV}$ ) unless noted.

c Thermal fluence rate corrected for epithermal neutron contribution based on ${ }^{109} \mathrm{Ag}$ and ${ }^{59}$ Co reaction rates and their cross sections.

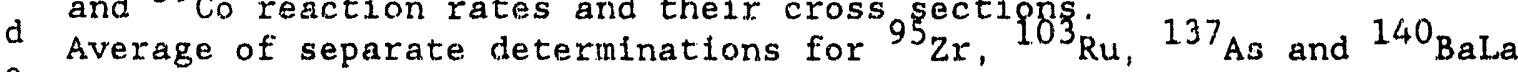

e Calcuted spectrum value.

Summary, Capsule UBR-83A

1. Average neutron fluence; $2.63 \times 10^{18} \mathrm{n} / \mathrm{cm}^{2} \mathrm{E}>1 \mathrm{MeV}$ (calculated spectrum).

2. Average dpa $(E>1 \mathrm{MeV}): 3.9 \times 10^{-3}$

3. Exposure hours: 81.00 (B-4 facility) 


\section{REFERENCE}

A.1 J. W, Rogers, "Neutron Fluence Rates for MEA-UBR Experiments," Letter Report JWR-30-92, Idaho Nuclear Engineering Laboratory, May 28, 1992. 
APPENDIX B

Reactor Operations History: Irradiation Assembly UBR-83A 
Table B-1 Exposure History

Experiment UBR-83A

\begin{tabular}{cclllll}
\hline $\begin{array}{c}\text { Date } \\
\text { In }\end{array}$ & $\begin{array}{c}\text { Time } \\
\text { In }\end{array}$ & $\begin{array}{l}\text { Date } \\
\text { Out }\end{array}$ & $\begin{array}{l}\text { Time } \\
\text { Out }\end{array}$ & $\begin{array}{c}\text { Exposure } \\
\text { Hours }\end{array}$ & $\begin{array}{c}\text { Sigma } \\
\text { Hours }\end{array}$ & $\begin{array}{c}\text { Core } \\
\text { Position }\end{array}$ \\
\hline $2-27-89$ & 2246 & $3-2-89$ & 1445 & 63.98 & 63.98 & B-4 \\
$3-02-89$ & 1550 & $3-3-89$ & 0851 & 17.02 & 81.00 & \\
\hline
\end{tabular}


APPENDIX $C$

Charpy-V Data Tabulations and Computer Curve Fits for Unirradiated Condition Tests and Irradiation Experiment UBR-83A Tests 
Tabulations of Chaxpy $-V$ Data

$\mathrm{C}-1$ 
Table C-1 Pre UBR Irradiation $C_{v}$ Data for Archive GEB-2 Material

\begin{tabular}{|c|c|c|c|c|c|c|c|c|}
\hline $\begin{array}{l}\text { Specimen } \\
\text { No. }{ }^{a}\end{array}$ & $\begin{array}{c}\text { ASTM } \\
\text { Orientation }\end{array}$ & $\begin{array}{l}\text { Tempe } \\
\left({ }^{\circ} \mathrm{C}\right)\end{array}$ & $\begin{array}{l}\text { ture } \\
\left({ }^{\circ} \mathrm{F}\right)\end{array}$ & $(\mathrm{J})^{\mathrm{E}}$ & $\begin{array}{l}\text { nergy } \\
(f t-1 b)\end{array}$ & $\begin{array}{l}\text { Lateral } \\
\quad(\mathrm{mm})\end{array}$ & $\begin{array}{l}\text { Expansion } \\
\text { (mils) }\end{array}$ & $\begin{array}{l}\text { Shear } \\
(8)\end{array}$ \\
\hline 400 & C-L & -62 & -79 & 20 & 15.0 & 0.356 & 14 & $<100$ \\
\hline 390 & $C-L$ & -51 & -60 & 47 & 34.5 & 0.711 & 28 & $<100$ \\
\hline 392 & $C-\bar{I}$ & -29 & -20 & 52 & 38.0 & 0.813 & 32 & $<100$ \\
\hline 388 & C-L & -18 & 0 & 69 & 51.0 & 1.016 & 40 & $<100$ \\
\hline 382 & $C-I$ & -1 & 30 & 91 & 67.0 & 1.422 & 56 & $<100$ \\
\hline 394 & $C-L$ & 24 & 75 & 117 & 86.0 & 1.676 & 66 & $<100$ \\
\hline 380 & $C-L$ & 116 & 240 & 157 & 116.0 & 2.337 & 92 & 100 \\
\hline 402 & $C-L$ & 116 & 240 & 157 & 115.5 & 1.854 & 73 & 100 \\
\hline 371 & L-C & -51 & -60 & 32 & 23.5 & 0.508 & 20 & $<100$ \\
\hline 363 & L-C & -29 & -20 & 44 & 32.5 & 0.737 & 29 & $<100$ \\
\hline 355 & $\mathrm{~L}-\mathrm{C}$ & -23 & -10 & 42 & 31.0 & 0.737 & 29 & $<100$ \\
\hline 361 & $L-C$ & -1 & 30 & 62 & 46.0 & 1.016 & 40 & $<1.00$ \\
\hline 351 & L-C & 18 & 65 & 86 & 63.5 & 1.372 & 54 & $<100$ \\
\hline 377 & L-C & 24 & 75 & 99 & 73.0 & 1.676 & 66 & $<100$ \\
\hline 357 & L-C & 116 & 240 & 114 & 84.0 & 1.676 & 66 & 100 \\
\hline 359 & L-C & 116 & 240 & 108 & 80.0 & 1.448 & 57 & 100 \\
\hline
\end{tabular}

a specimen taken frorn $1 / 8 \mathrm{~T}$ thickness layer of the material. 
Table C-2 Pre UBR Irradiation $C_{y}$ Data for KRB-A Vessel

Trepans C, D, G (Courtesty MPA)

\begin{tabular}{|c|c|c|c|c|c|c|}
\hline $\begin{array}{c}\text { Layer } \\
8\end{array}$ & $\frac{\text { Trepan }}{\mathrm{C}}$ & $\frac{\begin{array}{c}\text { ASTM } \\
\text { Orientation }\end{array}}{\mathrm{C}-\mathrm{L}}$ & \multicolumn{2}{|c|}{$\begin{array}{l}\text { Temperature } \\
\left({ }^{\circ} \mathrm{C}\right) \quad\left({ }^{\circ} \mathrm{F}\right)\end{array}$} & \multicolumn{2}{|c|}{ Energy } \\
\hline 8 & C & $C-I$ & $\begin{array}{r}-60 \\
-20 \\
10 \\
30 \\
40 \\
50 \\
275 \\
0 \\
20 \\
100\end{array}$ & $\begin{array}{r}-76 \\
-4 \\
50 \\
86 \\
104 \\
122 \\
527 \\
32 \\
68 \\
212\end{array}$ & $\begin{array}{c}10.5 \\
37 \\
54 \\
118 \\
84 \\
127.5 \\
154 \\
64.5 \\
78.5 \\
160.5\end{array}$ & $\begin{array}{r}8 \\
27 \\
40 \\
87 \\
62 \\
94 \\
114 \\
48 \\
58 \\
118\end{array}$ \\
\hline & C & $L-C$ & $\begin{array}{r}30 \\
50 \\
275\end{array}$ & $\begin{array}{r}86 \\
122 \\
527\end{array}$ & $\begin{array}{c}47 \\
61 \\
81.5\end{array}$ & $\begin{array}{l}35 \\
45 \\
60\end{array}$ \\
\hline & D & $L_{1}-C$ & $\begin{array}{r}0 \\
20 \\
30 \\
45 \\
60 \\
100 \\
200\end{array}$ & $\begin{array}{r}32 \\
68 \\
86 \\
113 \\
140 \\
212 \\
392\end{array}$ & $\begin{array}{c}21 \\
35.5 \\
51 \\
56 \\
68.5 \\
79 \\
79\end{array}$ & $\begin{array}{l}16 \\
26 \\
38 \\
41 \\
51 \\
58 \\
58\end{array}$ \\
\hline & G & $\mathrm{L}-\mathrm{C}$ & $\begin{array}{r}-20 \\
0 \\
10 \\
22 \\
40 \\
60 \\
100\end{array}$ & $\begin{array}{r}-4 \\
32 \\
50 \\
72 \\
104 \\
140 \\
212\end{array}$ & $\begin{array}{c}27 \\
33 \\
44.5 \\
34.5 \\
54 \\
75.5 \\
81\end{array}$ & $\begin{array}{l}20 \\
24 \\
33 \\
25 \\
40 \\
56 \\
60\end{array}$ \\
\hline 9 & C & $C-L$ & $\begin{array}{r}-60 \\
-40 \\
-20 \\
10 \\
40 \\
50 \\
275\end{array}$ & $\begin{array}{r}-76 \\
-40 \\
-4 \\
50 \\
104 \\
122 \\
527\end{array}$ & $\begin{array}{c}14.5 \\
18.5 \\
37 \\
53 \\
130 \\
161 \\
160\end{array}$ & $\begin{array}{r}11 \\
14 \\
27 \\
39 \\
96 \\
11.9 \\
118\end{array}$ \\
\hline & G & $C-L$ & $\begin{array}{r}0 \\
20 \\
100\end{array}$ & $\begin{array}{r}32 \\
68 \\
212\end{array}$ & $\begin{array}{r}52.5 \\
105.5 \\
153.5\end{array}$ & $\begin{array}{r}39 \\
78 \\
11.3\end{array}$ \\
\hline
\end{tabular}


Table C-2 Cont'd Pre UBR Irradiation $C_{v}$ Data for KRB-A Vessel Trepans C, D, G (Courtesty MPA)

\begin{tabular}{|c|c|c|c|c|c|c|}
\hline \multirow[t]{2}{*}{ Layer } & \multirow{2}{*}{$\underbrace{\text { Tren }}_{\text {Trepan }}$} & \multirow{2}{*}{$\frac{\begin{array}{c}\text { ASTM } \\
\text { Orientation }\end{array}}{\text { L-C }}$} & \multicolumn{2}{|c|}{$\begin{array}{l}\text { Temperature } \\
\left({ }^{\circ} \mathrm{C}\right) \quad\left({ }^{\circ} \mathrm{F}\right)\end{array}$} & \multicolumn{2}{|c|}{ Energy } \\
\hline & & & $\begin{array}{r}-40 \\
30 \\
275\end{array}$ & $\begin{array}{r}-40 \\
86 \\
527\end{array}$ & $\begin{array}{l}13 \\
53 \\
83\end{array}$ & $\begin{array}{l}10 \\
39 \\
61\end{array}$ \\
\hline & D & $L-C$ & $\begin{array}{r}0 \\
20 \\
30 \\
40 \\
60 \\
100 \\
200\end{array}$ & $\begin{array}{r}32 \\
68 \\
86 \\
104 \\
140 \\
212 \\
392\end{array}$ & $\begin{array}{c}30.5 \\
34 \\
43.5 \\
53 \\
69.5 \\
82.5 \\
81\end{array}$ & $\begin{array}{l}23 \\
25 \\
32 \\
39 \\
51 \\
61 \\
60\end{array}$ \\
\hline & G & $L-C$ & $\begin{array}{r}-20 \\
0 \\
10 \\
22 \\
40 \\
60 \\
100\end{array}$ & $\begin{array}{r}-4 \\
32 \\
50 \\
72 \\
104 \\
140 \\
212\end{array}$ & $\begin{array}{c}29 \\
25 \\
29 \\
45.5 \\
77 \\
75 \\
83\end{array}$ & $\begin{array}{l}21 \\
18 \\
21 \\
34 \\
57 \\
55 \\
61\end{array}$ \\
\hline 10 & $\mathrm{C}$ & $C-L$ & $\begin{array}{r}-40 \\
-20 \\
0 \\
10 \\
50 \\
275\end{array}$ & $\begin{array}{r}-40 \\
-4 \\
32 \\
50 \\
122 \\
527\end{array}$ & $\begin{array}{c}16.5 \\
52.5 \\
46 \\
76 \\
146 \\
158\end{array}$ & $\begin{array}{r}12 \\
39 \\
34 \\
56 \\
108 \\
117\end{array}$ \\
\hline & G & $C-L$ & $\begin{array}{r}0 \\
20 \\
100\end{array}$ & $\begin{array}{r}32 \\
68 \\
212\end{array}$ & $\begin{array}{l}38.5 \\
117 \\
153\end{array}$ & $\begin{array}{r}28 \\
86 \\
113\end{array}$ \\
\hline & C & L-C & $\begin{array}{r}-40 \\
30 \\
275\end{array}$ & $\begin{array}{r}-40 \\
86 \\
527\end{array}$ & $\begin{array}{l}15.5 \\
38.5 \\
83.5\end{array}$ & $\begin{array}{l}11 . \\
28 \\
62\end{array}$ \\
\hline & D & L-C & $\begin{array}{r}0 \\
20 \\
30 \\
40 \\
60 \\
100 \\
200\end{array}$ & $\begin{array}{r}32 \\
68 \\
86 \\
104 \\
140 \\
212 \\
392\end{array}$ & $\begin{array}{c}29 \\
40.5 \\
59.5 \\
52.5 \\
88 \\
82.5 \\
83\end{array}$ & $\begin{array}{l}21 \\
30 \\
44 \\
39 \\
65 \\
61 \\
61\end{array}$ \\
\hline
\end{tabular}


Table C-2 Cont'd Pre UBR Irradiation $C_{v}$ Data for KRB-A Vesse1 Trepans C, D, G (Courtesty MPA)

\begin{tabular}{|c|c|c|c|c|c|c|}
\hline \multirow[t]{2}{*}{ Layer } & \multirow{2}{*}{$\frac{\text { Trepan }}{G}$} & \multirow{2}{*}{$\frac{\begin{array}{c}\text { ASTM } \\
\text { Orientation }\end{array}}{\text { L-C }}$} & \multicolumn{2}{|c|}{$\begin{array}{l}\text { Temperature } \\
\left({ }^{\circ} \mathrm{C}\right) \quad\left({ }^{\circ} \mathrm{F}\right)\end{array}$} & \multicolumn{2}{|c|}{ Energy } \\
\hline & & & $\begin{array}{r}-20 \\
0 \\
10 \\
22 \\
40 \\
60 \\
100\end{array}$ & $\begin{array}{r}-4 \\
32 \\
50 \\
72 \\
104 \\
140 \\
212\end{array}$ & $\begin{array}{c}25 \\
24.5 \\
36.5 \\
53 \\
65.5 \\
88 \\
88\end{array}$ & $\begin{array}{l}18 \\
18 \\
27 \\
39 \\
48 \\
65 \\
65\end{array}$ \\
\hline
\end{tabular}


Table C-3 Post UBR Irradiation $C_{v}$ Data for Archive GEB-2 Material

\begin{tabular}{|c|c|c|c|c|c|c|c|c|}
\hline $\begin{array}{l}\text { Specimen } \\
\text { No. }\end{array}$ & $\begin{array}{c}\text { ASTM } \\
\text { Orientation }\end{array}$ & $\begin{array}{l}\text { Temper } \\
\left({ }^{\circ} \mathrm{C}\right)\end{array}$ & $\begin{array}{l}\text { ture } \\
\left({ }^{\circ} \mathrm{F}\right)\end{array}$ & $(J)^{\operatorname{Er}}$ & $\begin{array}{l}\text { ergy } \\
(f t-1 b)\end{array}$ & $\begin{array}{l}\text { Lateral } \\
\quad(\mathrm{mm})\end{array}$ & $\begin{array}{c}\text { Expansion } \\
\text { (mils) }\end{array}$ & $\begin{array}{l}\text { Shear } \\
(8)\end{array}$ \\
\hline 396 & $C-I$ & -57 & -70 & 14 & 10.0 & 0.152 & 6 & $<100$ \\
\hline 387 & $C-I$ & -40 & -40 & 29 & 21.5 & 0.432 & 17 & $<100$ \\
\hline 391 & $C-\mathrm{L}$ & -34 & -30 & 31 & 23.0 & 0.508 & 20 & $<100$ \\
\hline 393 & $C \cdot I$ & -23 & -10 & 55 & 40.5 & 0.868 & 34 & $<100$ \\
\hline 379 & $C-L$ & -7 & 20 & 62 & 46.0 & 0.991 & 39 & $<100$ \\
\hline 401 & $C-L$ & 10 & 50 & 73 & 54.0 & 1.168 & 46 & $<100$ \\
\hline 399 & $C-L$ & 27 & 80 & 90 & 66.5 & 1.372 & 54 & $<100$ \\
\hline 395 & $C-L$ & 43 & 110 & 121 & 89.0 & 1.473 & 58 & $<100$ \\
\hline 397 & $C-L$ & 93 & 200 & 138 & 101.5 & 1.854 & 73 & 99 \\
\hline 381 & $C-L$ & 116 & 240 & 156 & 115.0 & 2.540 & 100 & 100 \\
\hline 398 & $C-L$ & 116 & 240 & 139 & 102.5 & 2.362 & 93 & 100 \\
\hline $389^{b}$ & $C-L$ & - & - & - & - & - & - & - \\
\hline 354 & $L-C$ & -40 & -40 & 27 & 20.0 & 0.432 & 17 & $<100$ \\
\hline 360 & $L-C$ & -23 & -10 & 33 & 24.5 & 0.635 & 25 & $<100$ \\
\hline 358 & L-C & -7 & 20 & 33 & 24.0 & 0.635 & 25 & $<100$ \\
\hline 352 & L.C & -1 & 30 & 45 & 33.0 & 0.711 & 28 & $<100$ \\
\hline 364 & L-C & 4 & 40 & 49 & 36.5 & 0.889 & 35 & $<100$ \\
\hline 372 & L-C & 10 & 50 & 53 & 39.0 & 0.991 & 39 & $<100$ \\
\hline 362 & $\mathrm{~L}-\mathrm{C}$ & 27 & 80 & 69 & 51.0 & 1.219 & 48 & $<100$ \\
\hline 378 & $\mathrm{~L}-\mathrm{C}$ & 43 & 110 & 87 & 64.0 & 1.626 & 64 & $<100$ \\
\hline 375 & $L-C$ & 74 & 165 & 101 & 74.5 & 1.575 & 62 & 98 \\
\hline 356 & $L-C$ & 11.6 & 240 & 106 & 78.0 & 1.880 & 74 & 100 \\
\hline 374 & $\mathrm{~L}-\mathrm{C}$ & 116 & 240 & 100 & 74.0 & 1.524 & 60 & 100 \\
\hline 376 & L-C & 177 & 350 & 95 & 70.0 & 1.727 & 68 & 100 \\
\hline
\end{tabular}

a specimen taken from 1/8T thickness layer of material.

b specimen "lost" in testing. 
Table C-4 Post UBR Irradiation $C_{\mathrm{v}}$ Data for Txepan P Material

\begin{tabular}{|c|c|c|c|c|c|c|c|c|c|}
\hline $\begin{array}{l}\text { Trepan P } \\
\text { Layer }\end{array}$ & $\begin{array}{l}\text { Specimen } \\
\text { No. }\end{array}$ & $\begin{array}{c}\mathrm{ASTM} \\
\text { Orientation }\end{array}$ & $\begin{array}{l}\text { Tempe } \\
\left({ }^{\circ} \mathrm{C}\right)\end{array}$ & $\begin{array}{l}\text { ature } \\
\left({ }^{\circ} \mathrm{F}\right)\end{array}$ & $(\mathrm{J})$ & $\begin{array}{l}\text { nergy } \\
(f t-1 b)\end{array}$ & $\begin{array}{l}\text { Lateral } \\
(\mathrm{mm})\end{array}$ & $\begin{array}{l}\text { Expansion } \\
\text { (mils) }\end{array}$ & $\begin{array}{c}\text { Shear } \\
(8)\end{array}$ \\
\hline 8 & $\begin{array}{l}\text { P8-1 } \\
\text { P8-2 } \\
\text { P8-3 }\end{array}$ & $\begin{array}{l}C-L \\
C-L \\
C-L\end{array}$ & $\begin{array}{r}49 \\
116 \\
4\end{array}$ & $\begin{array}{r}120 \\
240 \\
40\end{array}$ & $\begin{array}{r}92 \\
139 \\
39\end{array}$ & $\begin{array}{r}67.5 \\
102.5 \\
28.5\end{array}$ & $\begin{array}{l}1.321 \\
1.854 \\
0.711\end{array}$ & $\begin{array}{l}52 \\
73 \\
28\end{array}$ & $\begin{array}{r}<100 \\
100 \\
<100\end{array}$ \\
\hline 9 & P9-1 & C-L & 21 & 70 & 64 & 47.0 & 1.194 & 47 & $<100$ \\
\hline 10 & $\begin{array}{l}\text { P10- } 1 \\
\text { P10-2 } \\
\text { P10-3 }\end{array}$ & $\begin{array}{l}C-L \\
C-L \\
C-L\end{array}$ & $\begin{array}{r}116 \\
74 \\
13\end{array}$ & $\begin{array}{r}240 \\
165 \\
55\end{array}$ & $\begin{array}{r}127 \\
113 \\
47\end{array}$ & $\begin{array}{l}93.5 \\
83.0 \\
34.5\end{array}$ & $\begin{array}{l}1.803 \\
1.676 \\
0.868\end{array}$ & $\begin{array}{l}71 \\
66 \\
34\end{array}$ & $\begin{array}{r}98 \\
<100 \\
<100\end{array}$ \\
\hline 11 & $\begin{array}{l}\text { P11-1 } \\
\text { P1I-2 } \\
\text { P11-3 }\end{array}$ & $\begin{array}{l}C-L \\
C-I \\
C-L\end{array}$ & $\begin{array}{r}-18 \\
29 \\
116\end{array}$ & $\begin{array}{r}0 \\
85 \\
240\end{array}$ & $\begin{array}{r}197 \\
89 \\
138\end{array}$ & $\begin{array}{r}14.5 \\
66.0 \\
102.0\end{array}$ & $\begin{array}{l}0.254 \\
1.295 \\
1.651\end{array}$ & $\begin{array}{l}10 \\
51 \\
65\end{array}$ & $\begin{array}{r}<1.00 \\
<100 \\
100\end{array}$ \\
\hline 10 & $\begin{array}{l}\text { P10-4 } \\
\text { P10-6 } \\
\text { P10-7 } \\
\text { P10-9 } \\
\text { P10-10 }\end{array}$ & $\begin{array}{l}\text { L-C } \\
L-C \\
L-C \\
L-C \\
L-C\end{array}$ & $\begin{array}{r}116 \\
18 \\
116 \\
-18 \\
49\end{array}$ & $\begin{array}{r}240 \\
65 \\
240 \\
0 \\
120\end{array}$ & $\begin{array}{l}79 \\
33 \\
81 \\
17 \\
43\end{array}$ & $\begin{array}{r}58.0 \\
24.0 \\
59.5 \\
12.5 \\
\cdot 31.5\end{array}$ & $\begin{array}{l}1.778 \\
0.610 \\
1.397 \\
0.203 \\
0.813\end{array}$ & $\begin{array}{r}70 \\
24 \\
55 \\
8 \\
32\end{array}$ & $\begin{array}{r}99 \\
<100 \\
100 \\
<100 \\
<100\end{array}$ \\
\hline 11 & $\begin{array}{l}\text { P11-6 } \\
\text { P11-7 } \\
\text { P11-8 } \\
\text { P11-9 } \\
\text { P11-10 }\end{array}$ & $\begin{array}{l}L-C \\
L-C \\
L-C \\
L-C \\
L-C\end{array}$ & $\begin{array}{r}116 \\
66 \\
27 \\
4 \\
60\end{array}$ & $\begin{array}{r}240 \\
150 \\
80 \\
40 \\
140\end{array}$ & $\begin{array}{l}81 \\
62 \\
43 \\
30 \\
61\end{array}$ & $\begin{array}{l}60.0 \\
45.5 \\
32.0 \\
22.0 \\
45.0\end{array}$ & $\begin{array}{l}1.499 \\
1.143 \\
0.838 \\
0.584 \\
1.016\end{array}$ & $\begin{array}{l}59 \\
45 \\
33 \\
23 \\
40\end{array}$ & $\begin{array}{l}100 \\
<100 \\
<100 \\
<100 \\
<100\end{array}$ \\
\hline 9 & $\begin{array}{l}P 9.2^{\mathrm{A}} \\
P 9.6^{\mathrm{a}}\end{array}$ & $\begin{array}{l}C-L \\
L-C\end{array}$ & $\therefore$ & - & - & - & - & - & - \\
\hline
\end{tabular}

a Specimen not tested (held in reserve). 
Computer Curve Fits of Charpy-V Data $\Xi-8$ 
OVERVIEW

The data curve fitting procedure employed the hyperbolic tangent (Tanh) curve fitting method as given by:

$$
C_{v}=A+B \tanh \frac{T-T_{0}}{C}
$$

Parameters $A, B, C$ and $T_{0}$ are determined from non-linear regression analysis.

The quality of the fit to each data set generally depends upon the number of specimens tested and the availability of data defining the upper shelf and lower shelf for the data set. For many of the present data sets, both requirements are satisfied and an acceptable curve fit results. In other cases, either few testswere conducted or the data did not adequately define the lowex shelf for the data set. For such cases, the lower shelf frorn a standard Tanh fit gives a lower shelf which is either above $27 \mathrm{~J},(20 \mathrm{ft}-\mathrm{lb})$ or negative. Since such results are not satisfactory from either engineering or aesthetic standpoints, two modified curve fits (Case $A$ and Case B) can be applied.

Case A is the result obtained when four fictitious data points with $7 \mathrm{~J}$ ( $5 \mathrm{ft}-1 \mathrm{~b}$ ) of energy absorption are added at a temperature that is $28^{\circ} \mathrm{C}\left(50^{\circ} \mathrm{F}\right)$ below the intercept with the abscissa, of a line representing a linearized transition region. The line in this case is an eyeball fit to the data; the choice of a larger temperature shift (up to $56^{\circ} \mathrm{C}$ or $100^{\circ} \mathrm{F}$ ) generally is found not to influence the result appreciably. Case $B$ represents use of a fixed lower shelf of $7 \mathrm{~J}$ ( $5 \mathrm{ft}-1 \mathrm{~b}$ ); this lower shelf is attained at a temperature of $-\infty$.

The use of the modified curve fits serve to force the curves to a reasonably low, positive value in the lowere shelf region. This device is particularly useful for those cases where data are lacking in the lower shelf region for guiding the computer in its setting of bounding conditions. It should be noted that the American Soclety for Testing and Materials has not issued a standard method or a standard guide for curve-fitting $C_{v}$ data for the irradiated conditon

Within this appendix, the first curvefit sheet for a given material/materia? condition represents a standard evaluation using the Tanh equation. The second curvefit sheet if present, gives the Case A results. For Case A, the fictitious data points are denoted by "O" on the graph and in the data tabulation on the curvefit sheet. 


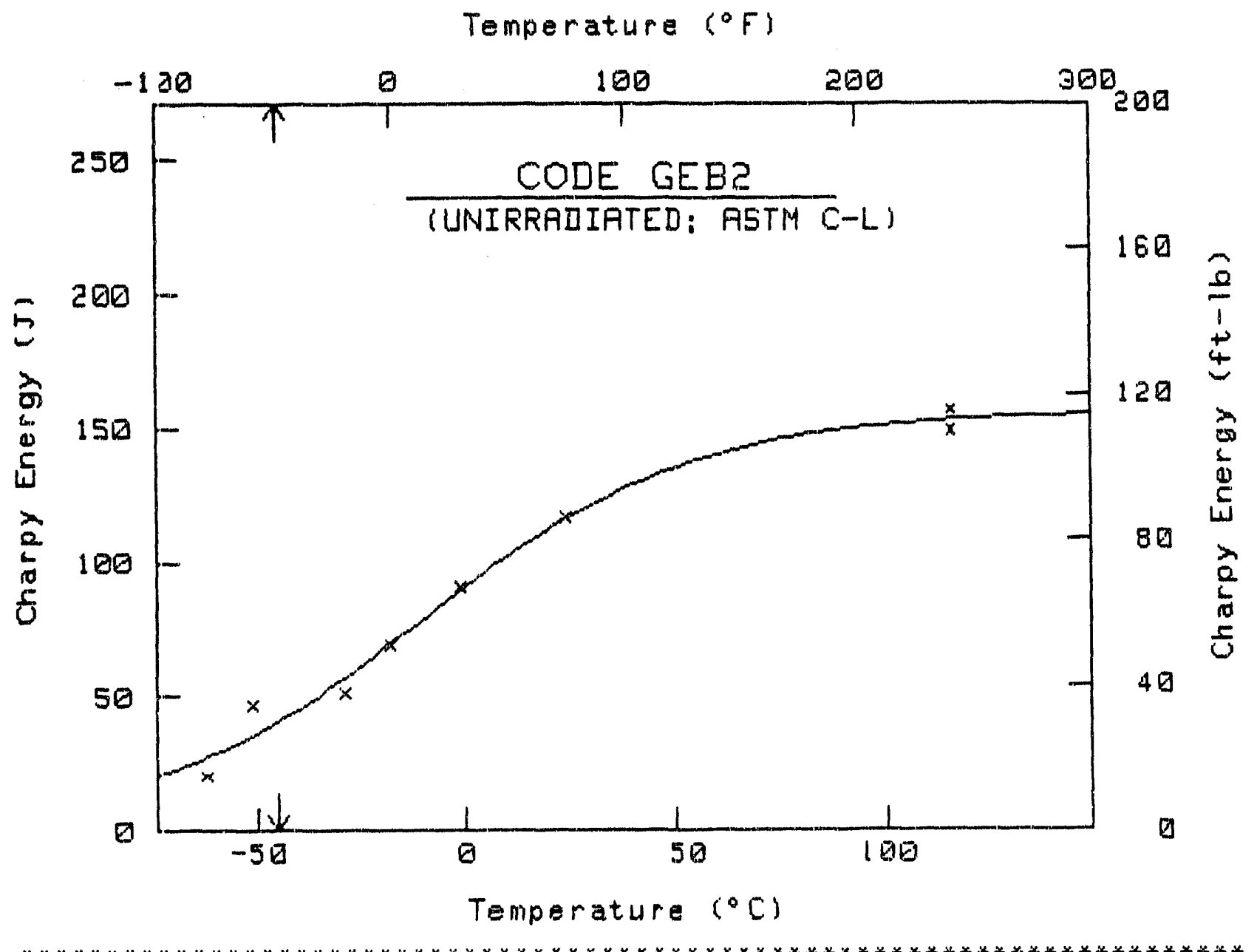

CU $=A+B R \operatorname{anh}[(T-T O)<C]$








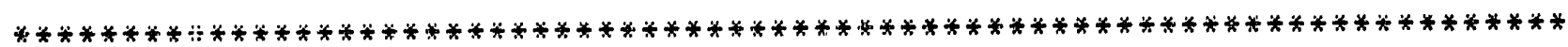
$C y=A+B \operatorname{anh}[(T-T O), C]$

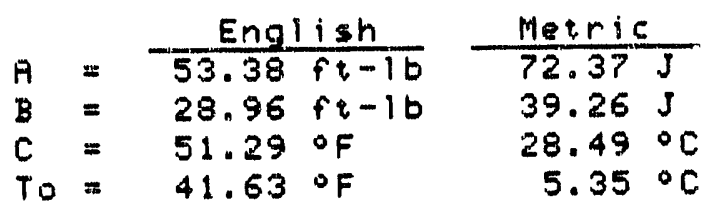

$\mathrm{Cu}=30 \mathrm{ft}-1 \mathrm{~b}\langle 41 \mathrm{~J}\rangle$ at $\mathrm{T}=-15.8 \circ \mathrm{F} \quad-26.5 \circ \mathrm{C}$ Upper Shelf Energy $=82.3 f i-1 b \quad 111.6 \mathrm{~J}$

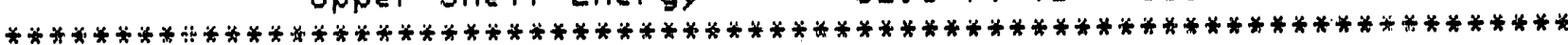

\begin{tabular}{rrr}
$P T$ & $\begin{array}{c}\text { Temp } \\
\text { (of) }\end{array}$ & $\begin{array}{c}\text { Energy } \\
(f t-10)\end{array}$ \\
\hline 1 & -60 & 23.5 \\
2 & -20 & 32.2 \\
3 & -10 & 31.0 \\
4 & 30 & 46.0 \\
5 & 65 & 63.5 \\
6 & 75 & 73.0 \\
7 & 240 & 80.0 \\
8 & 240 & 84.0
\end{tabular}

o = Fietitious Point Rdded

* Test Point Not Ineluded 


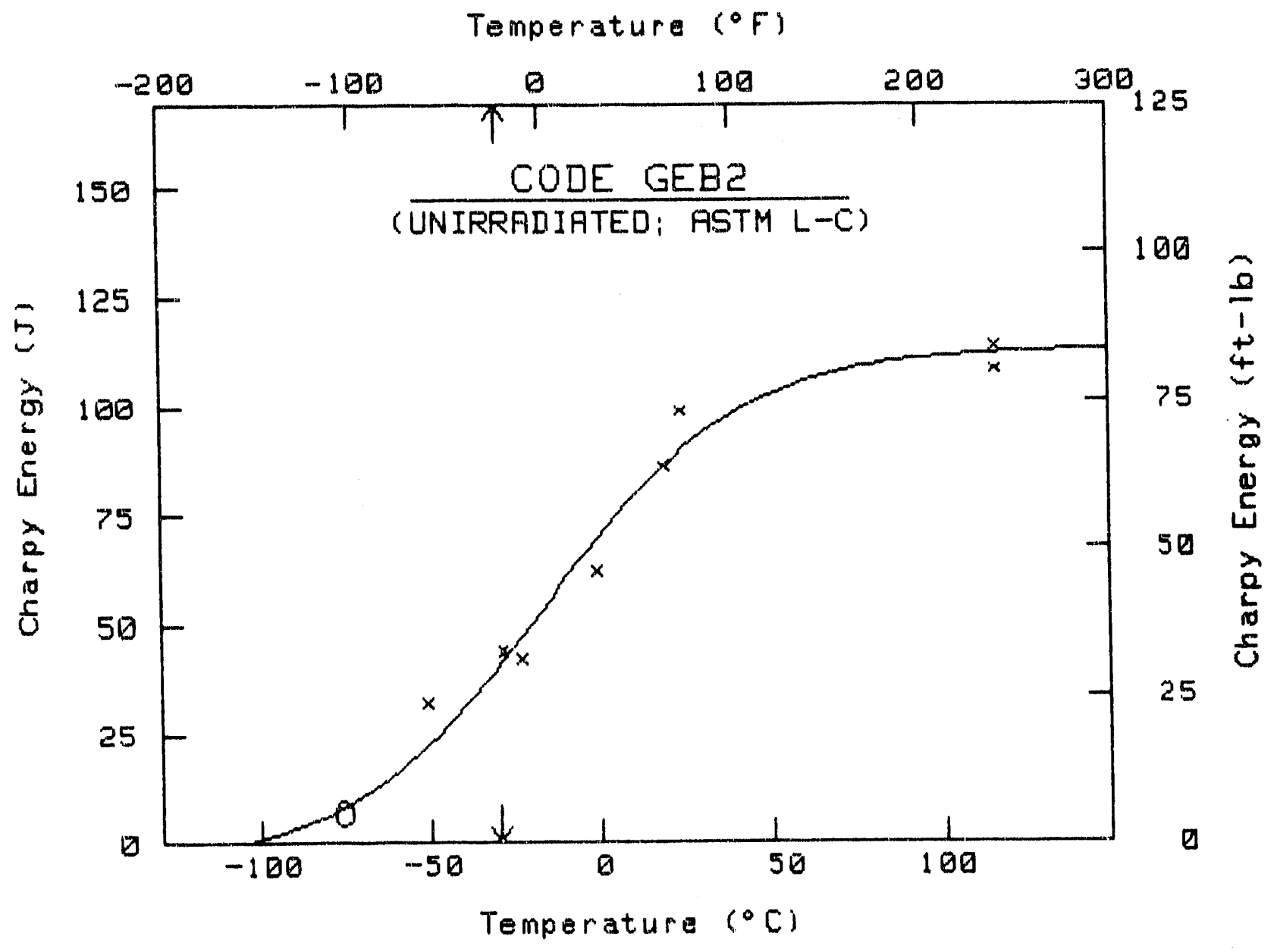

$* * * * * * * * * * * * * * * * * * * * * * * * * *$ if $* * * * * * * * * * * * * * * * * * * * * * * * * * * * * * * * * * * * * * * * * * * * *$ $C U=A+B \tanh \left[\left(T-T_{0}\right), C\right]$

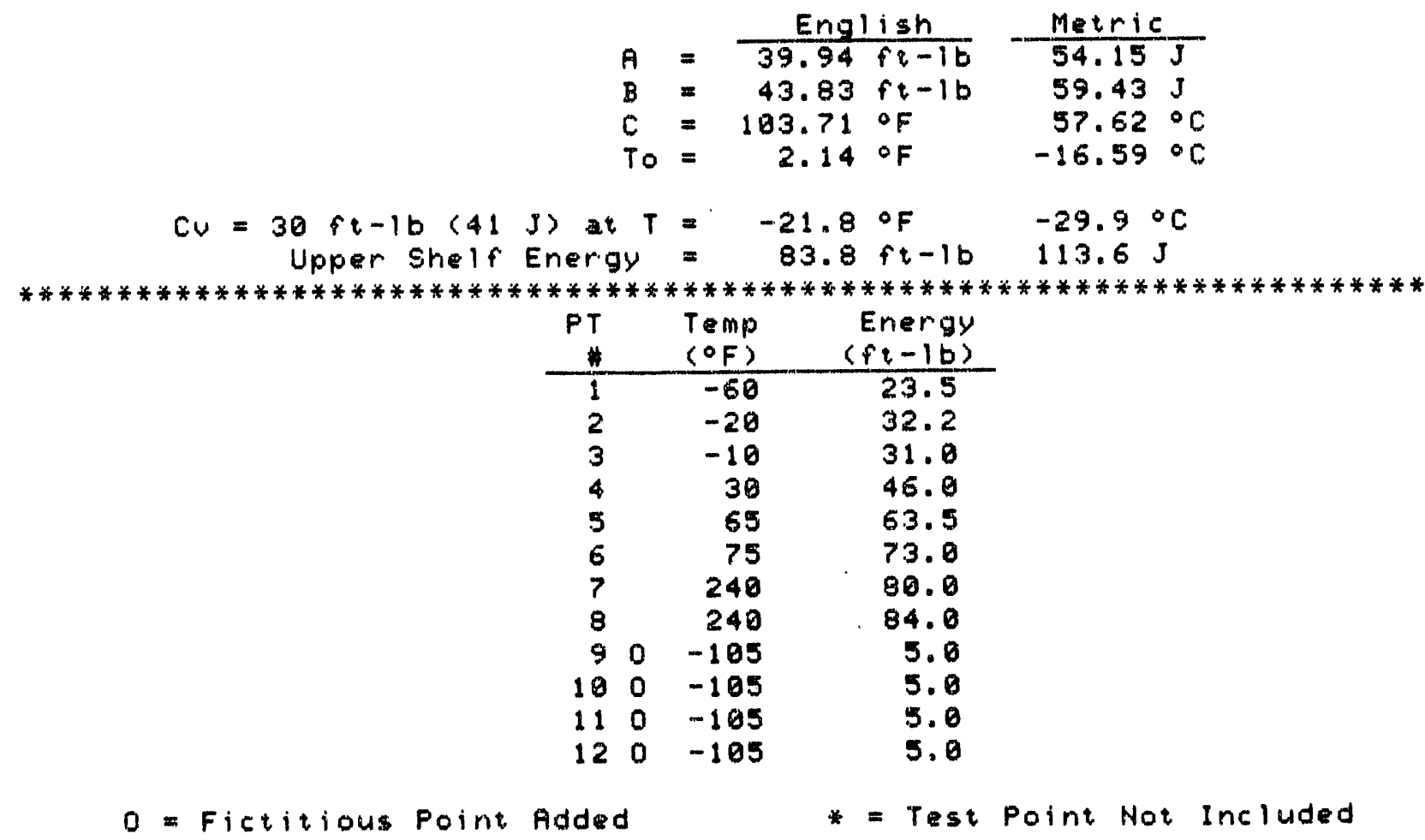




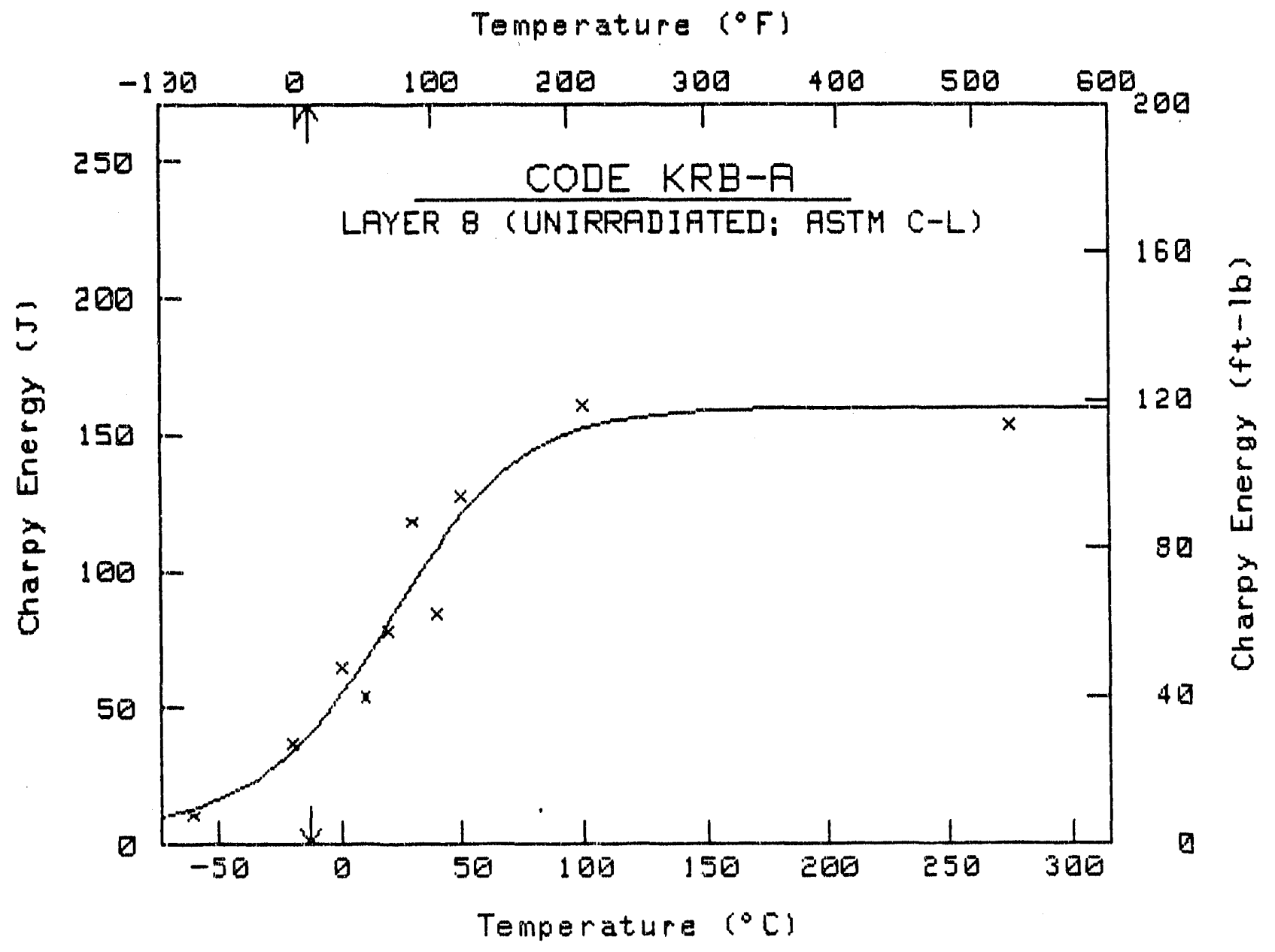

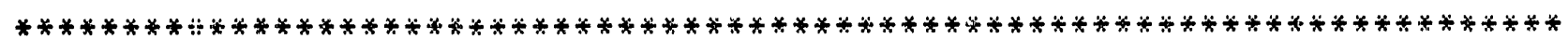
$C V=A+B \tanh [C T-T O S / C]$

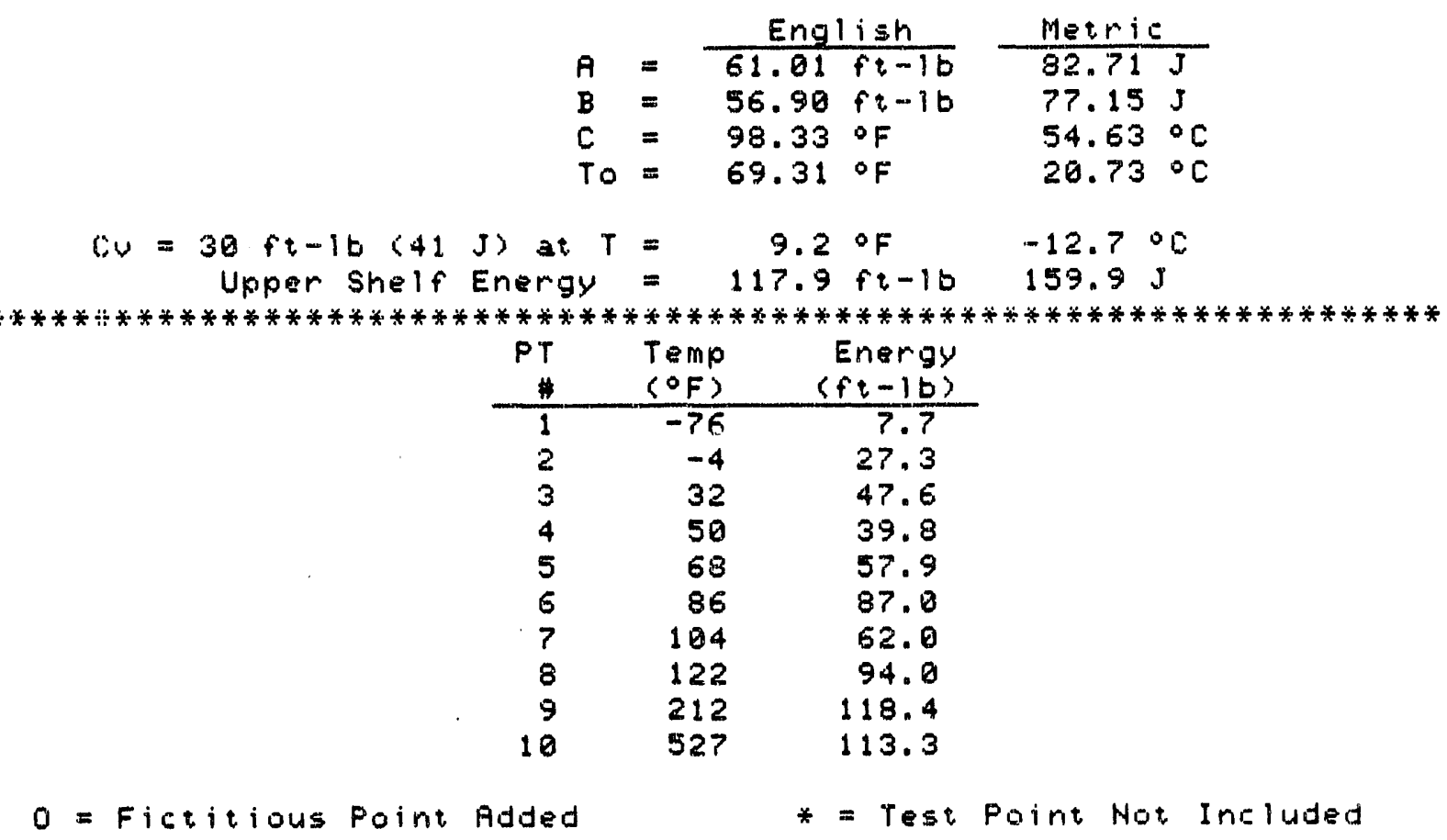




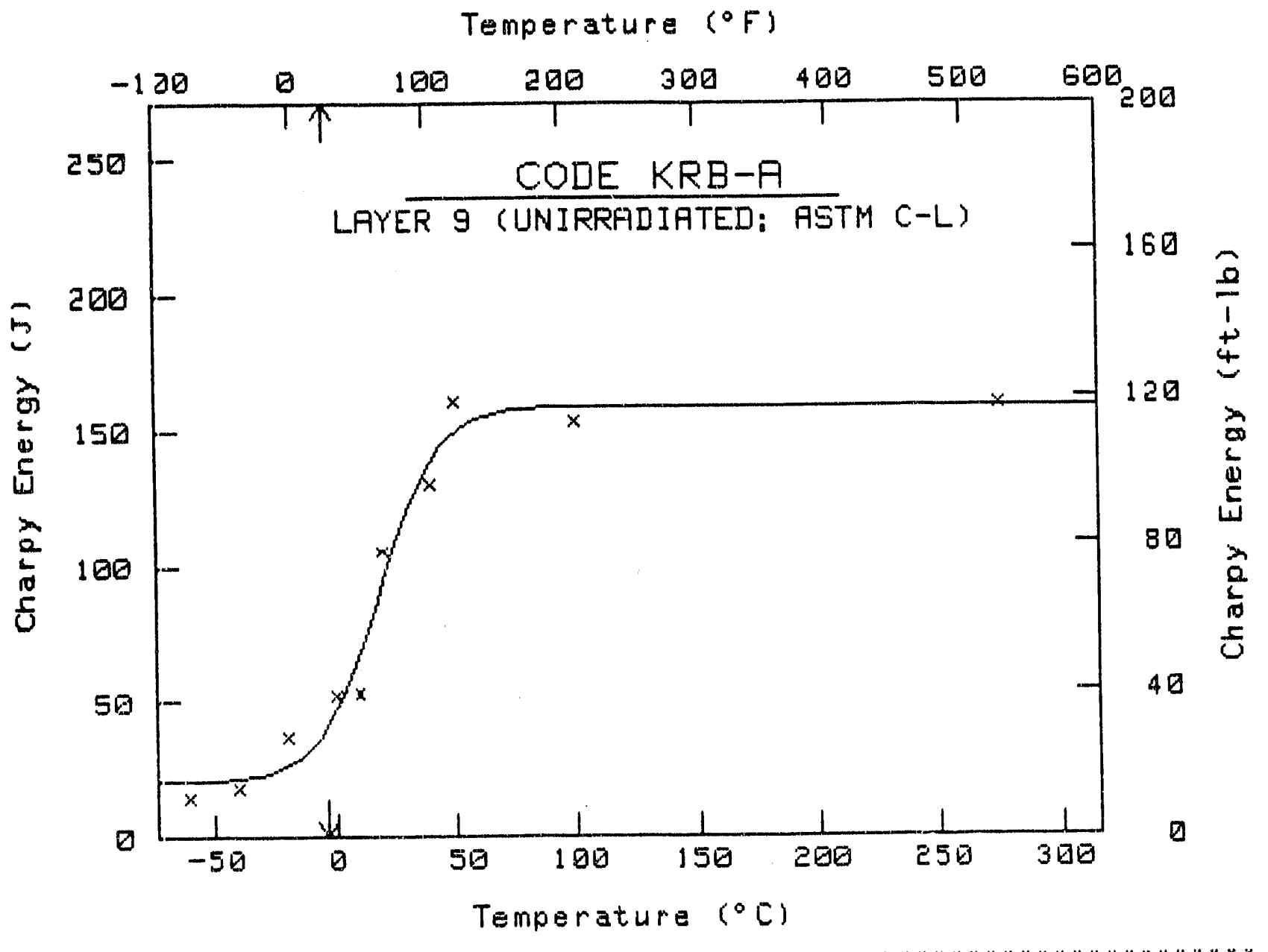

$C U=A+B \tanh \left[\left(T-T_{0}\right) / C\right]$

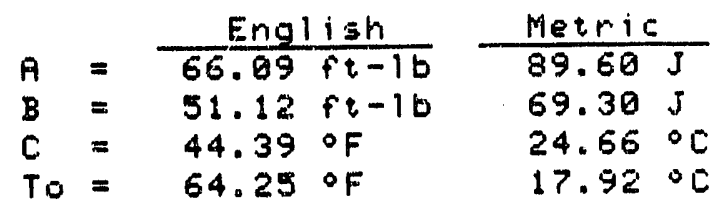

$C w=30 \mathrm{ft}-1 \mathrm{t}(41 \mathrm{~J})$ at $\mathrm{T}=25 . \mathrm{o}^{\circ} \mathrm{F} \quad-3.8^{\circ} \mathrm{C}$

Upper Shelf Energy $=117.2 \mathrm{ft}-1 \mathrm{~b} 158.9 \mathrm{~J}$

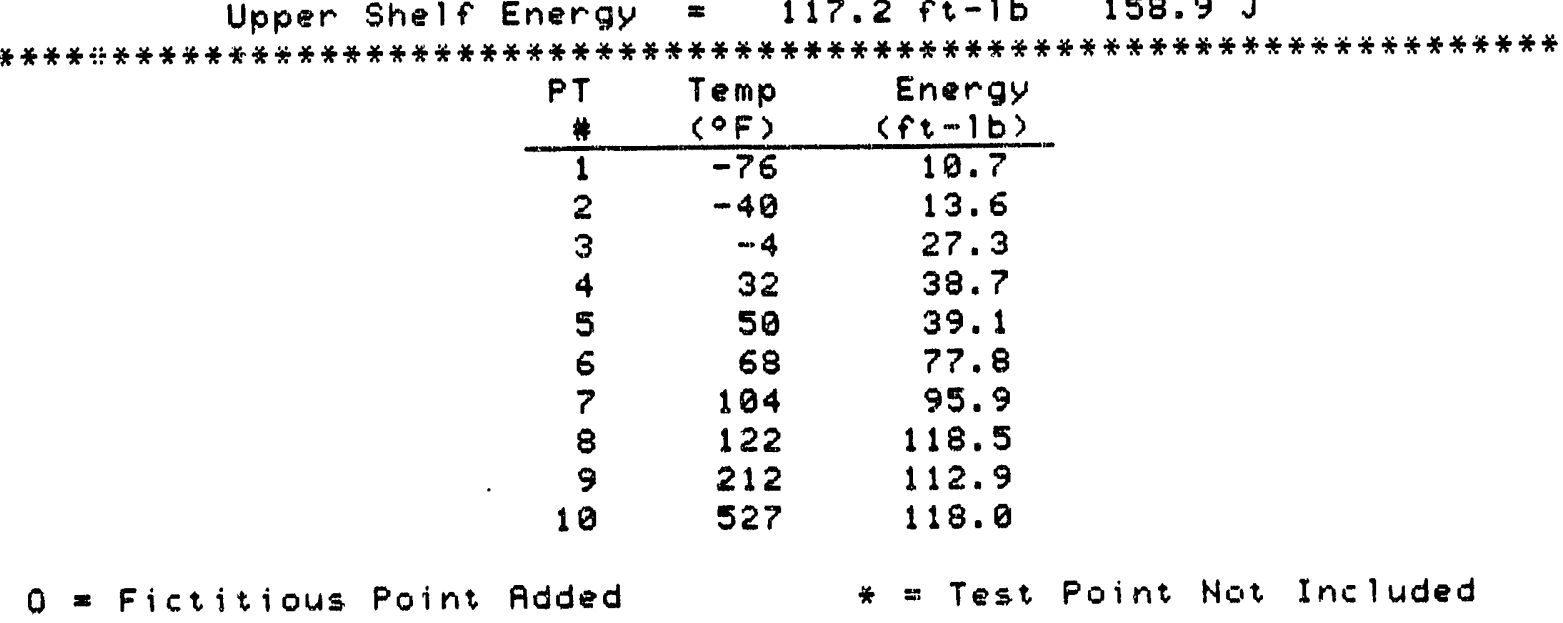






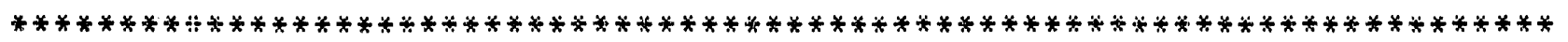
$\mathrm{CW}=\mathrm{A}+\mathrm{B} \tanh \left[\left(\mathrm{T}-\mathrm{T}_{0}\right)<\mathrm{C}\right]$

$$
\begin{aligned}
& A=\frac{\text { English }}{68.21 f t-16} \frac{\text { Metric }}{92.48 J} \\
& B=44.30 \mathrm{ft}-1 \mathrm{~b} \quad 60.06 \mathrm{~J} \\
& \mathrm{C}=23.66^{\circ} \mathrm{F} \quad 13.14{ }^{\circ} \mathrm{C} \\
& T_{0}=57.56^{\circ} \mathrm{F} \quad 14.20^{\circ} \mathrm{C}
\end{aligned}
$$

$\mathrm{Cu}=30 \mathrm{ft}-1 \mathrm{~b}\langle 41 \mathrm{~J}\rangle$ at $T=26.7^{\circ} \mathrm{F} \quad-2.9^{\circ} \mathrm{C}$ Upper Shelf Energy $=112.5 \mathrm{ft}-1 \mathrm{~b} 152.5 \mathrm{~J}$

$* * * * * * * *$ if $* * * * * * * * * * * * * * * * * * * * * * * * * * * * * * * * * * * * * * * * * * * * * * * * * * * * * * * * * * * * * * *$

\begin{tabular}{rrr} 
PT & $\begin{array}{c}\text { Temp } \\
\text { (oF) }\end{array}$ & $\begin{array}{r}\text { Energy } \\
(f t-1 b)\end{array}$ \\
\hline 1 & -40 & 12.2 \\
2 & -4 & 35.7 \\
3 & 32 & 28.4 \\
4 & 32 & 33.9 \\
5 & 50 & 56.1 \\
6 & 68 & 86.3 \\
7 & 122 & 107.7 \\
8 & 212 & 112.9 \\
9 & 527 & 116.5
\end{tabular}

$0=$ Fictitious Point Fdded

* = Test Point Not Included 

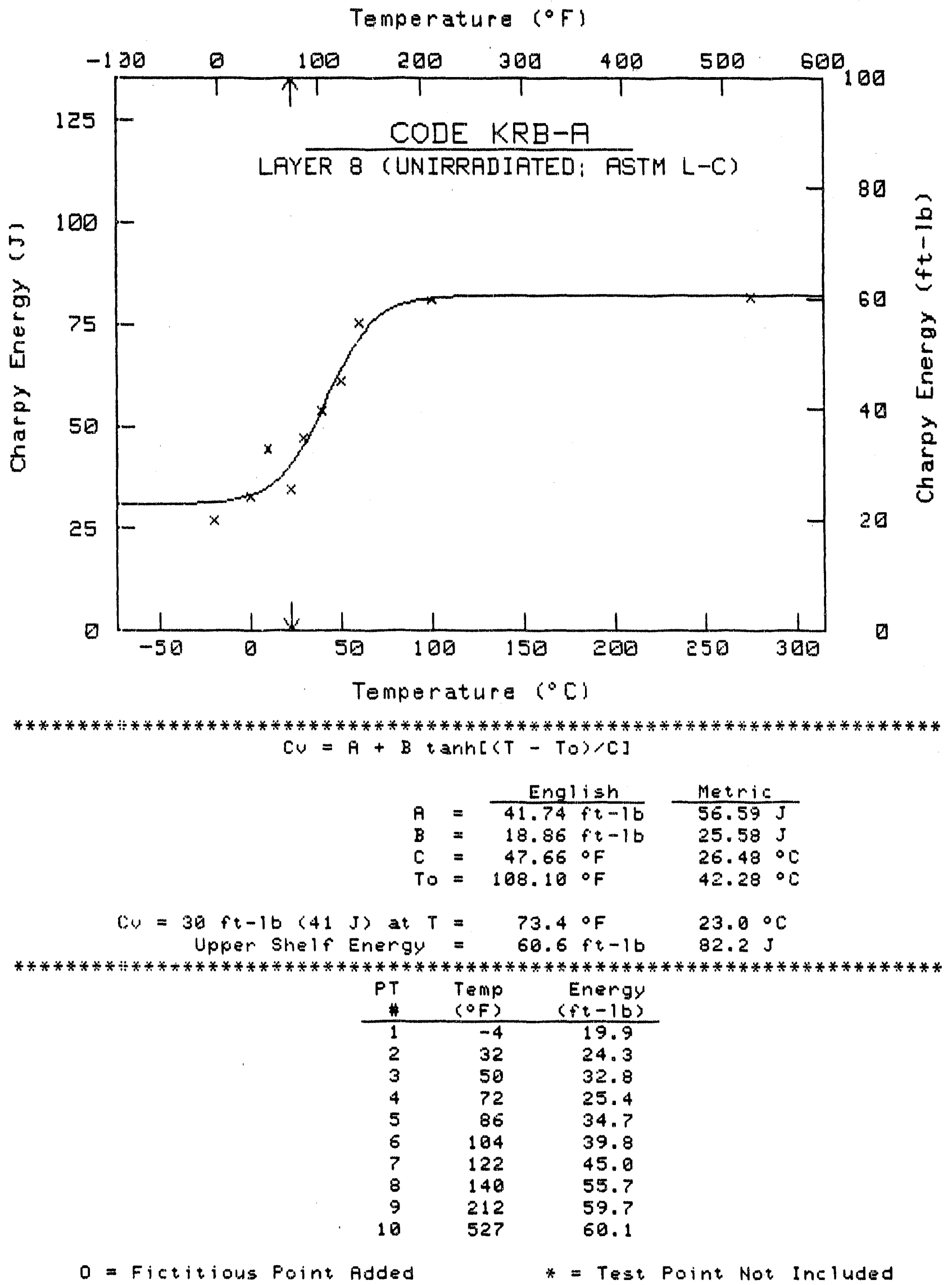


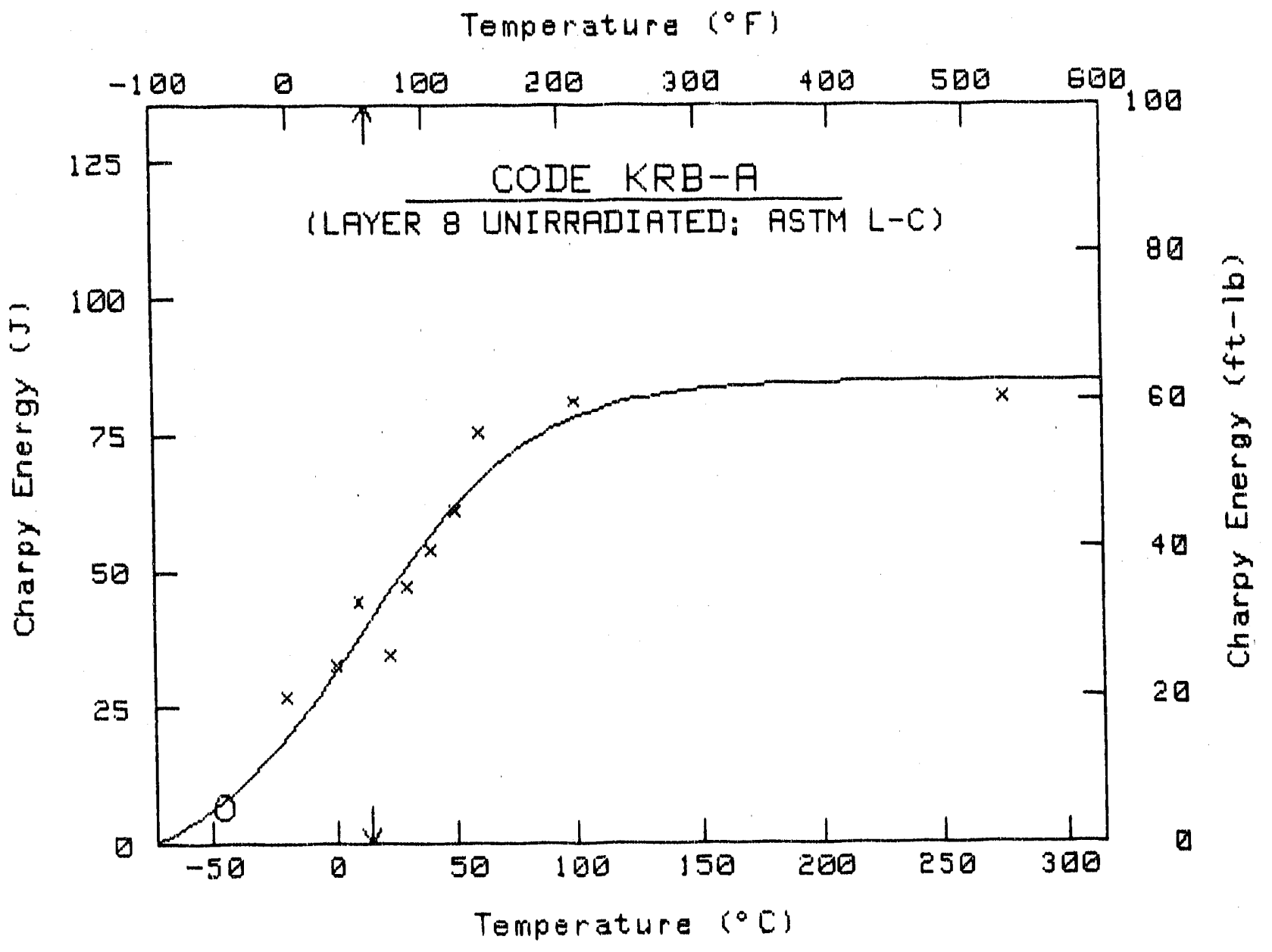

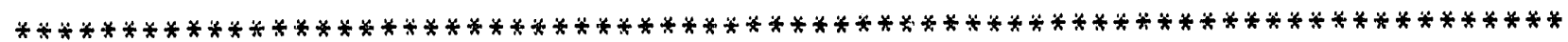
$C v=A+B \operatorname{anh}[C T-T 0)<C]$

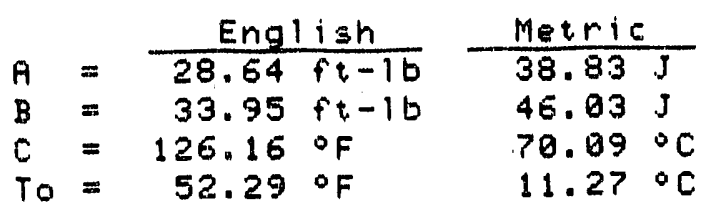$$
C_{W}=30 \mathrm{ft}-1 \mathrm{~b}(41 \mathrm{~J}) \text { at } T=57.3^{\circ} \mathrm{F} \quad 14.1^{\circ} \mathrm{C}
$$
Upper Shelf Energy $=62.8 \mathrm{ft}-1 \mathrm{~b} 84.9 \mathrm{~J}$

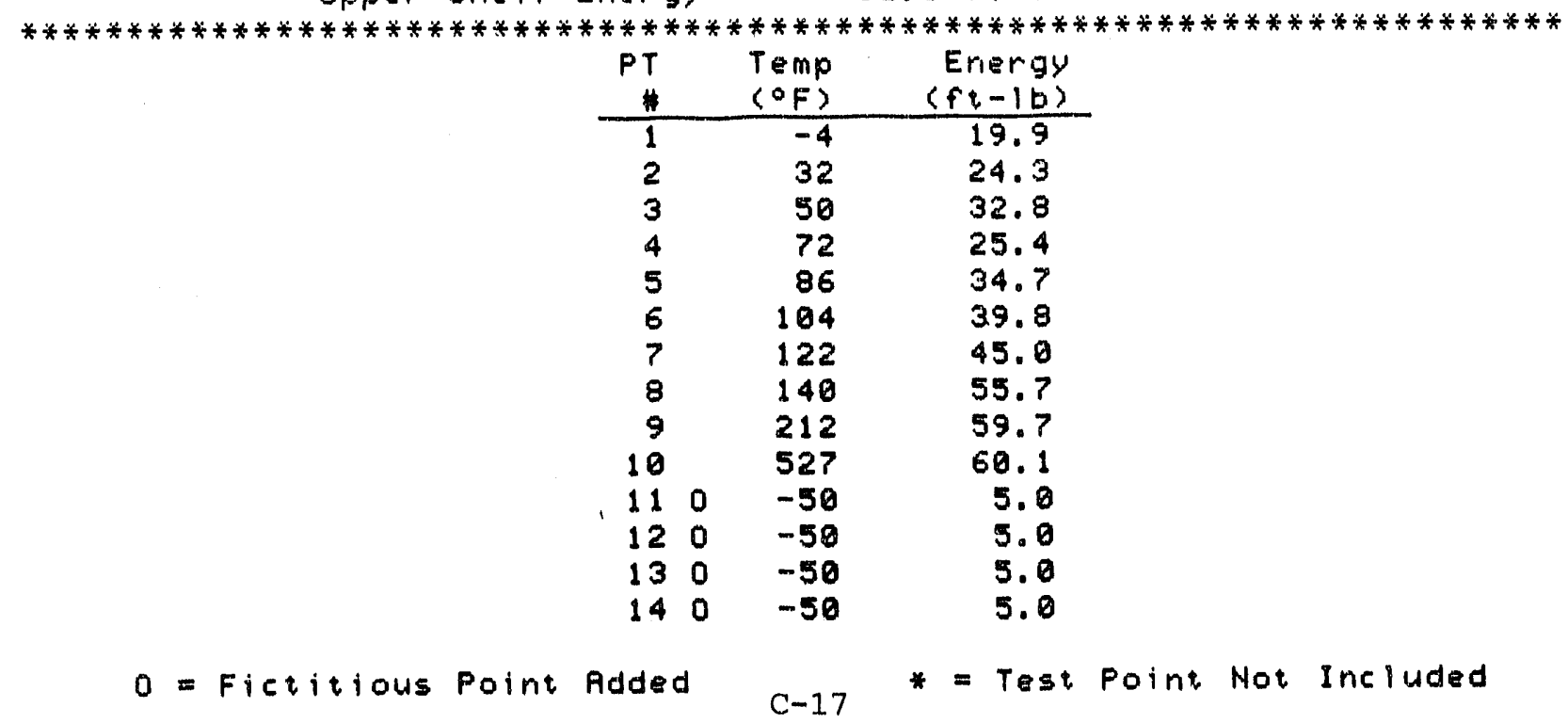




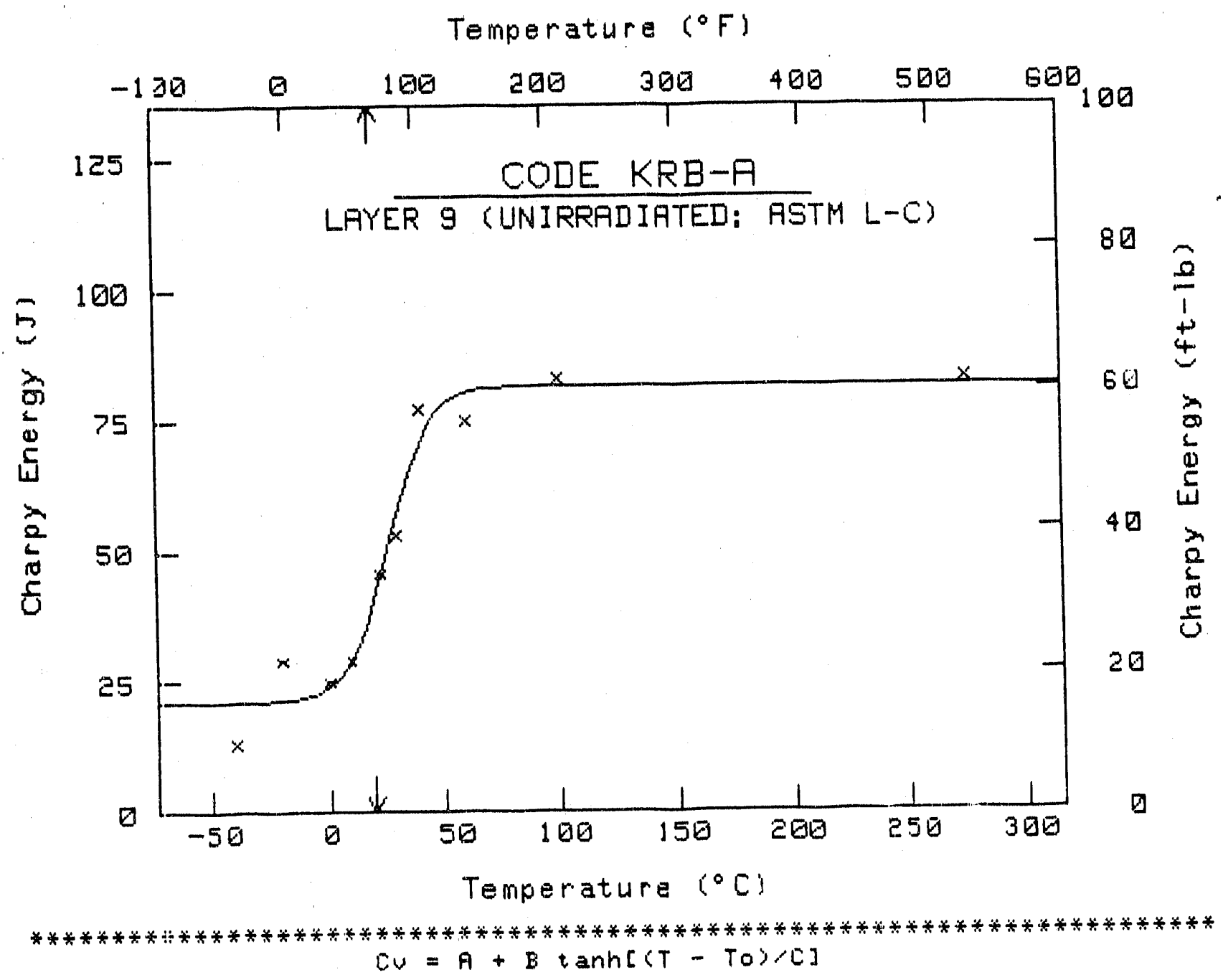




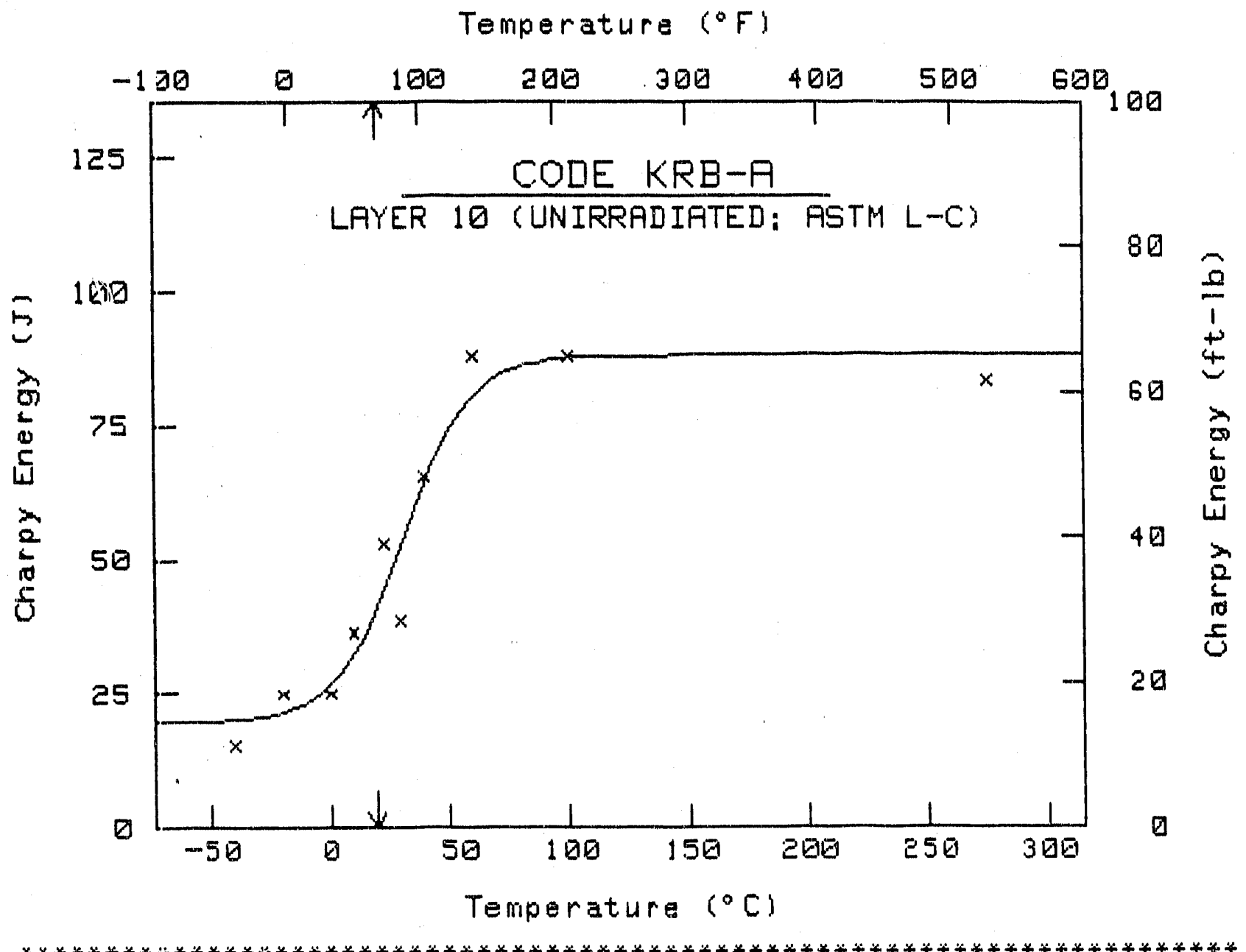

$\mathrm{CV}=\mathrm{A}+\mathrm{B} \tanh \left[\left(T-T_{0}\right) / C\right]$

$\begin{array}{llll}A & =\frac{\text { English }}{39.77 \mathrm{ft}-16} & \frac{\text { Metric }}{53.93 \mathrm{~J}} \\ \mathrm{~B}= & 25.25 \mathrm{ft}-1 \mathrm{~b} & 34.23 \mathrm{~J} \\ \mathrm{C}=51.19 \mathrm{o}^{\circ} & 28.44 \mathrm{C} \\ T_{0}=87.56 \mathrm{o}^{\circ} & 38.87 \mathrm{o}^{\circ}\end{array}$

$C V=30 \mathrm{ft}-1 \mathrm{~b}\langle 41 \mathrm{~J}\rangle$ at $\mathrm{T}=66 . \mathrm{C}^{\circ} \mathrm{F} \quad 19.3^{\circ} \mathrm{C}$ Upper Shelf Energy $=65.0 \mathrm{ft}-1 \mathrm{~b} \quad 38.2 \mathrm{~J}$



\begin{tabular}{rrc}
$P T$ & $\begin{array}{c}\text { Temp } \\
\text { (of) }\end{array}$ & $\begin{array}{c}\text { Energy } \\
(f t-10)\end{array}$ \\
\hline 1 & -40 & 11.4 \\
2 & -4 & 18.4 \\
3 & 32 & 18.4 \\
4 & 50 & 26.9 \\
5 & 72 & 39.1 \\
6 & 86 & 28.4 \\
7 & 104 & 48.3 \\
8 & 140 & 64.9 \\
9 & 212 & 64.9 \\
10 & 527 & 61.6
\end{tabular}

$0=$ Fictitious Foint Added

* = Test Point Not Included 

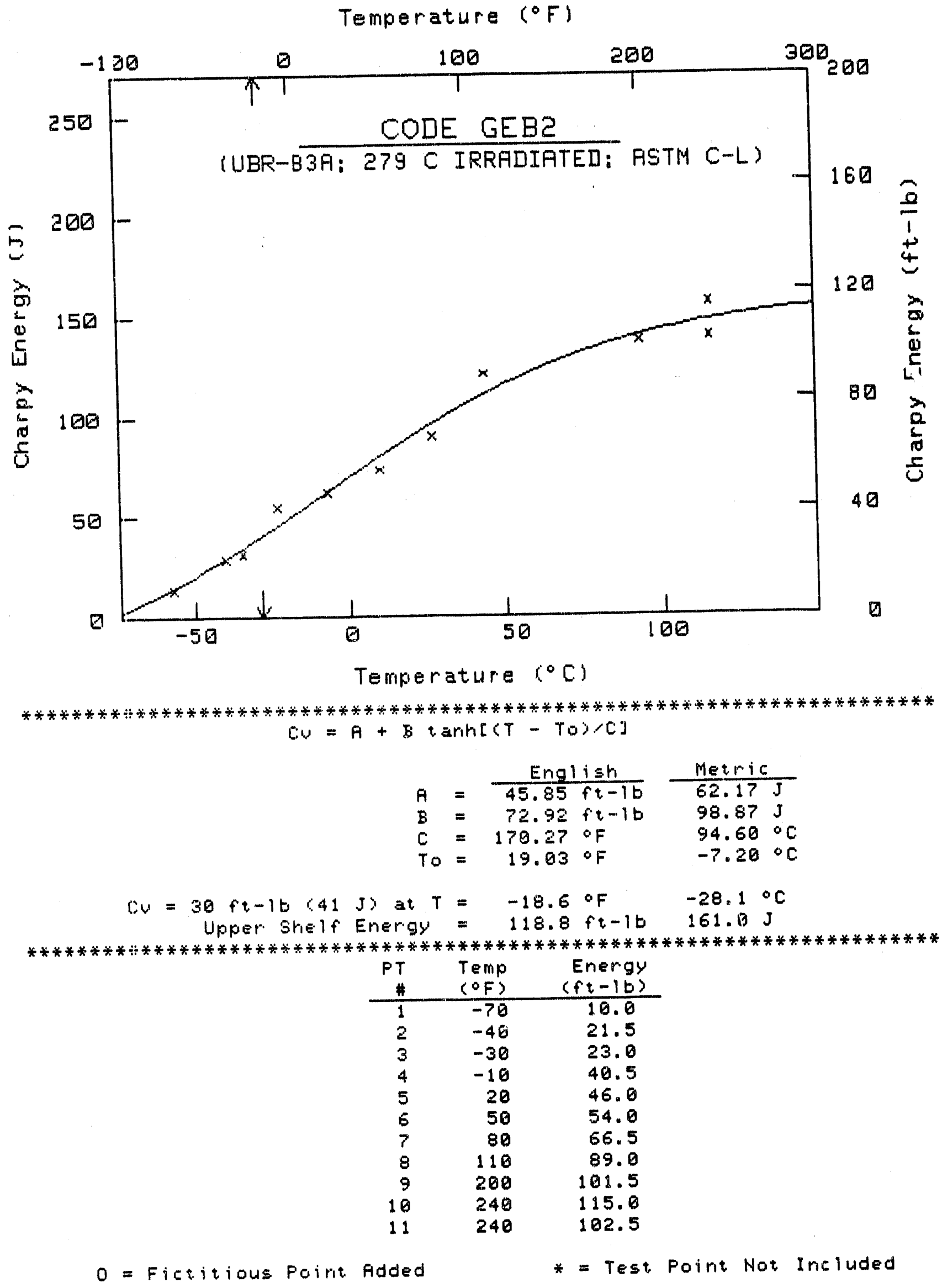


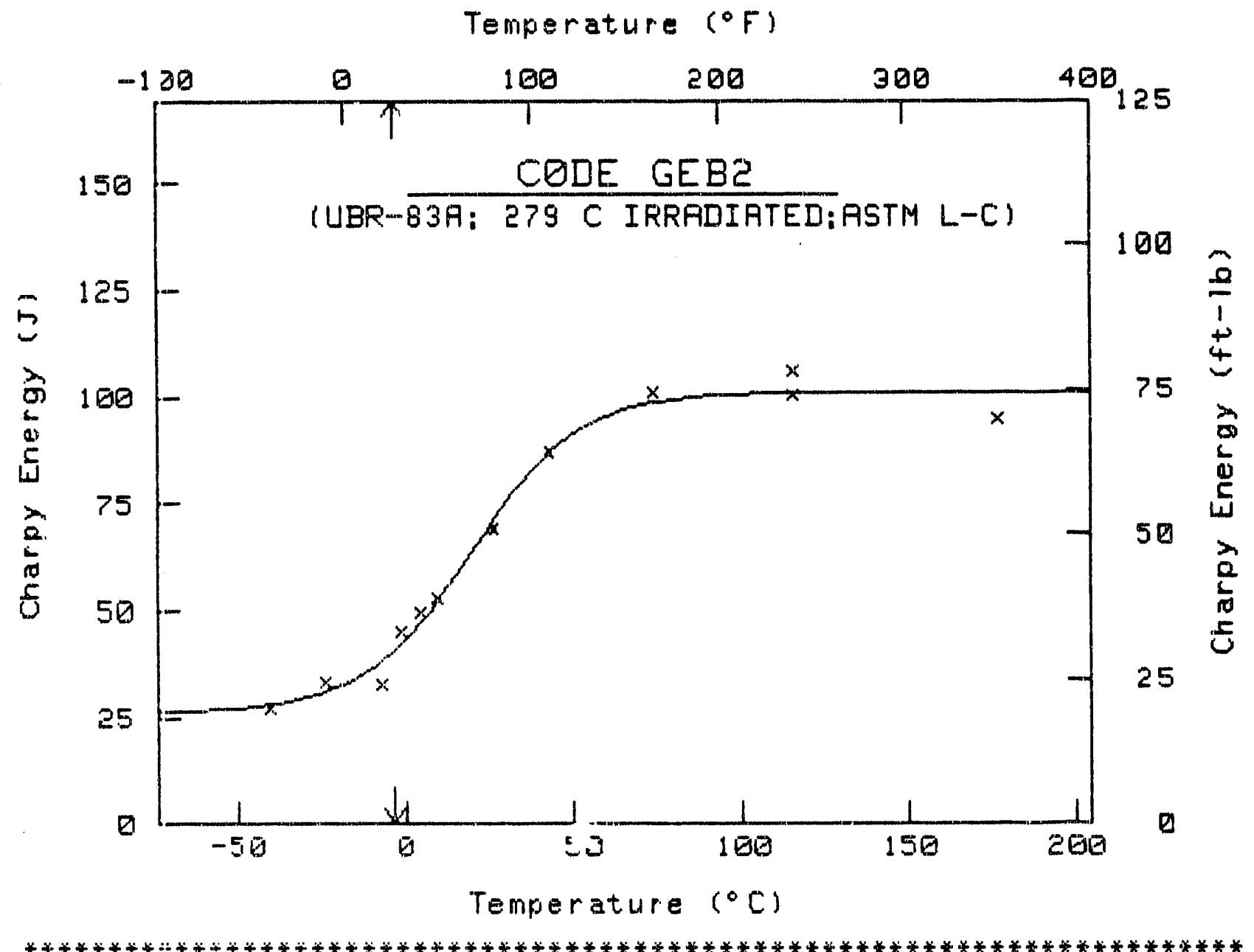

$C V=A+B t \operatorname{anh}\left[\left(T-T_{0}\right)>C\right]$

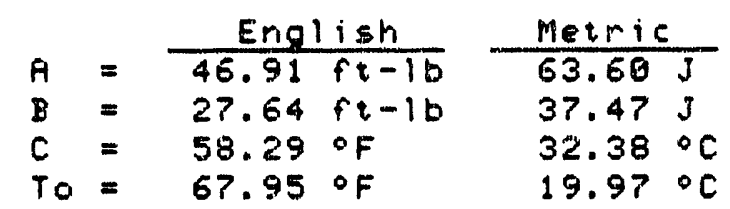$$
C v=30 f t-10(41 J) \text { at } T=26.5 \circ \mathrm{F} \cdot-3.1^{\circ} \mathrm{C}
$$$$
\text { Upper Shelf Energy }=74.5 \mathrm{ft}-10 \quad 101.1 \mathrm{~J}
$$

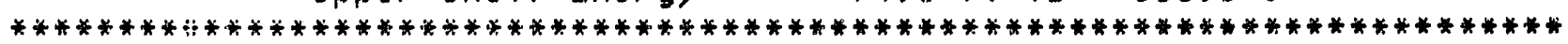

\begin{tabular}{ccc} 
PT & $\begin{array}{c}\text { Temp } \\
\text { (OF) }\end{array}$ & $\begin{array}{c}\text { Energy } \\
(f i-10)\end{array}$ \\
\hline 1 & -40 & 20.0 \\
2 & -10 & 24.5 \\
3 & 20 & 24.0 \\
4 & 30 & 33.0 \\
5 & 40 & 36.5 \\
6 & 50 & 39.0 \\
7 & 80 & 51.0 \\
8 & 110 & 64.0 \\
9 & 165 & 74.5 \\
10 & 240 & 74.0 \\
11 & 240 & 78.0 \\
12 & 358 & 79.0
\end{tabular}

$0=$ Fictitious Point foded

* Tese Point Not Included

$C-21$ 


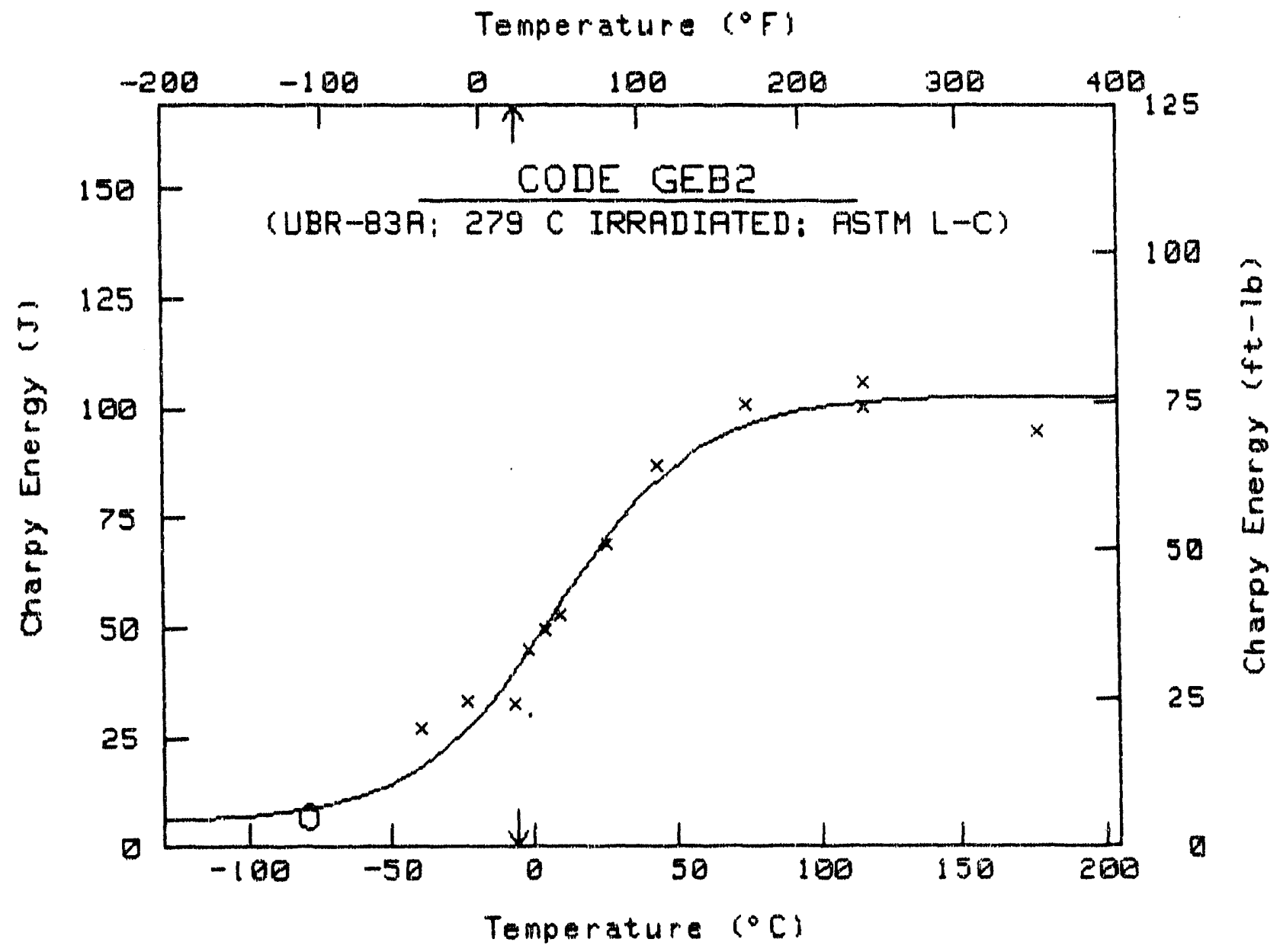

$C V=A+B \tanh \left[\left(T-T_{0}\right)<C\right]$

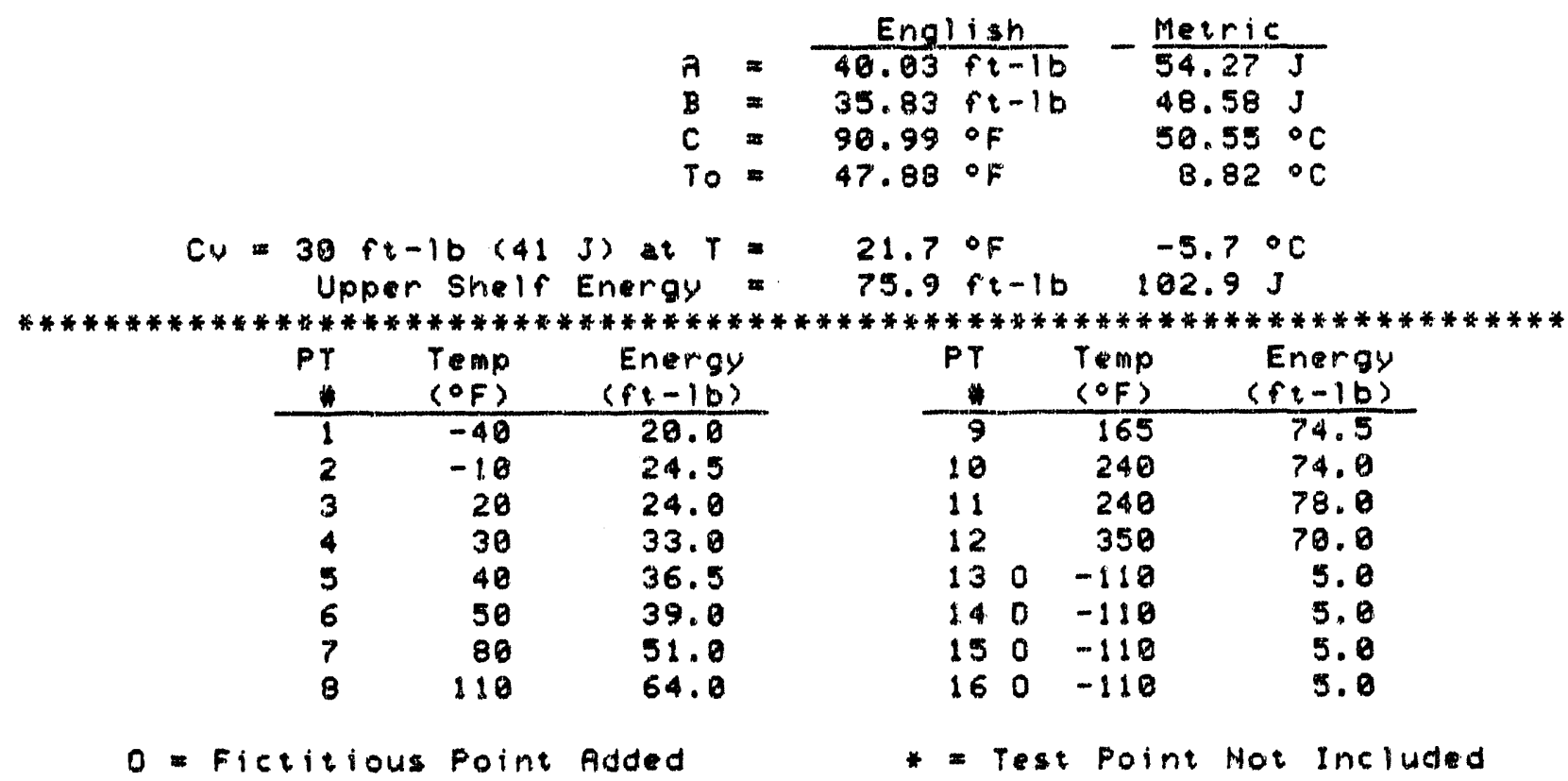




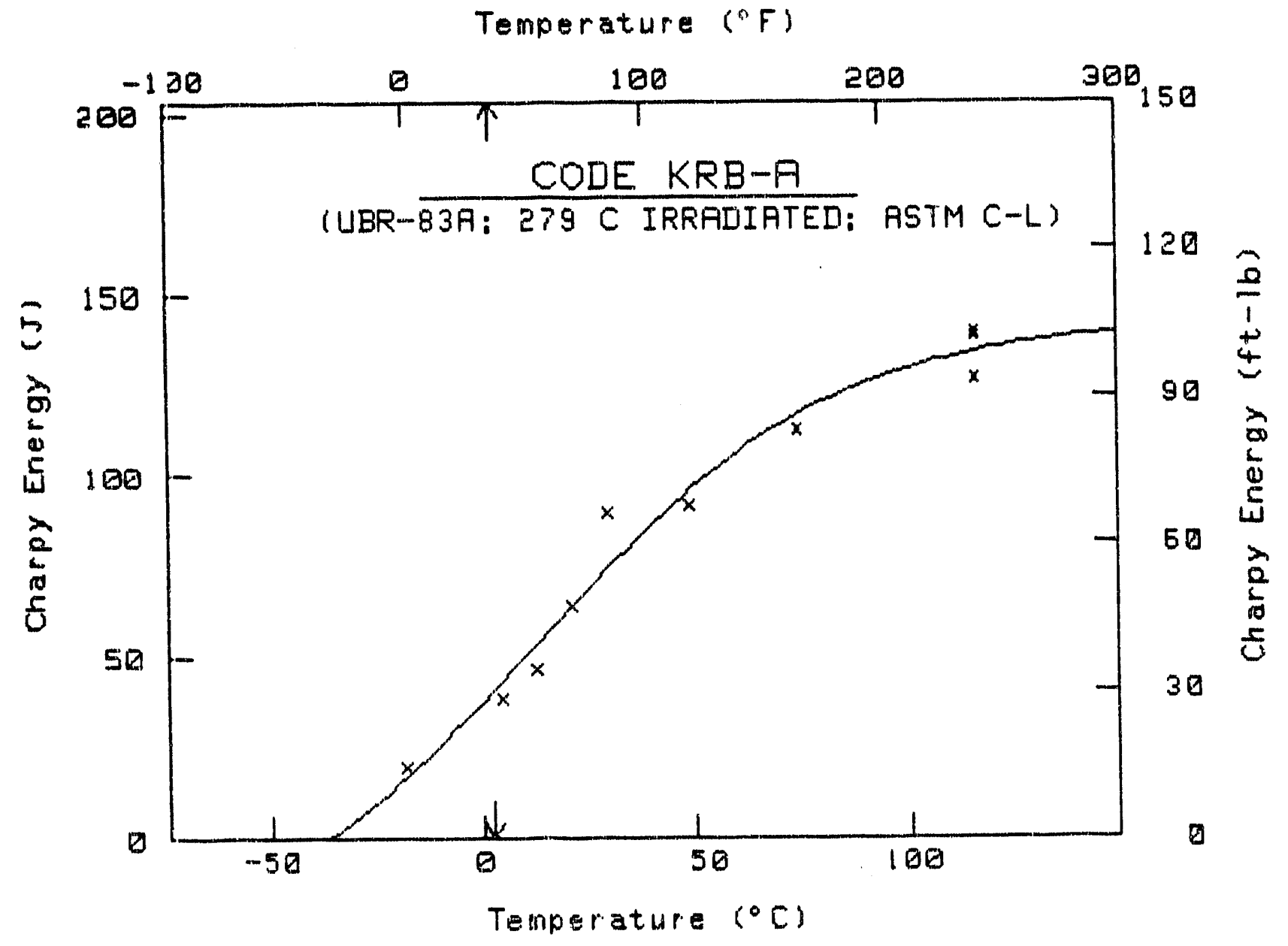

$C, y=A+B \tanh [(T-T 0), C]$

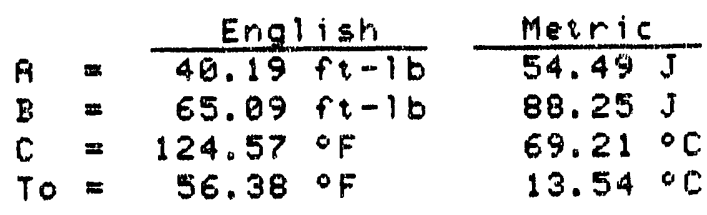

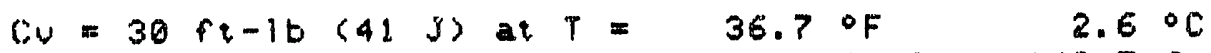$$
\text { Upper Shelf Energy }=105.3 \mathrm{ft}-1 \mathrm{~b} \quad 142.7 \mathrm{~J}
$$

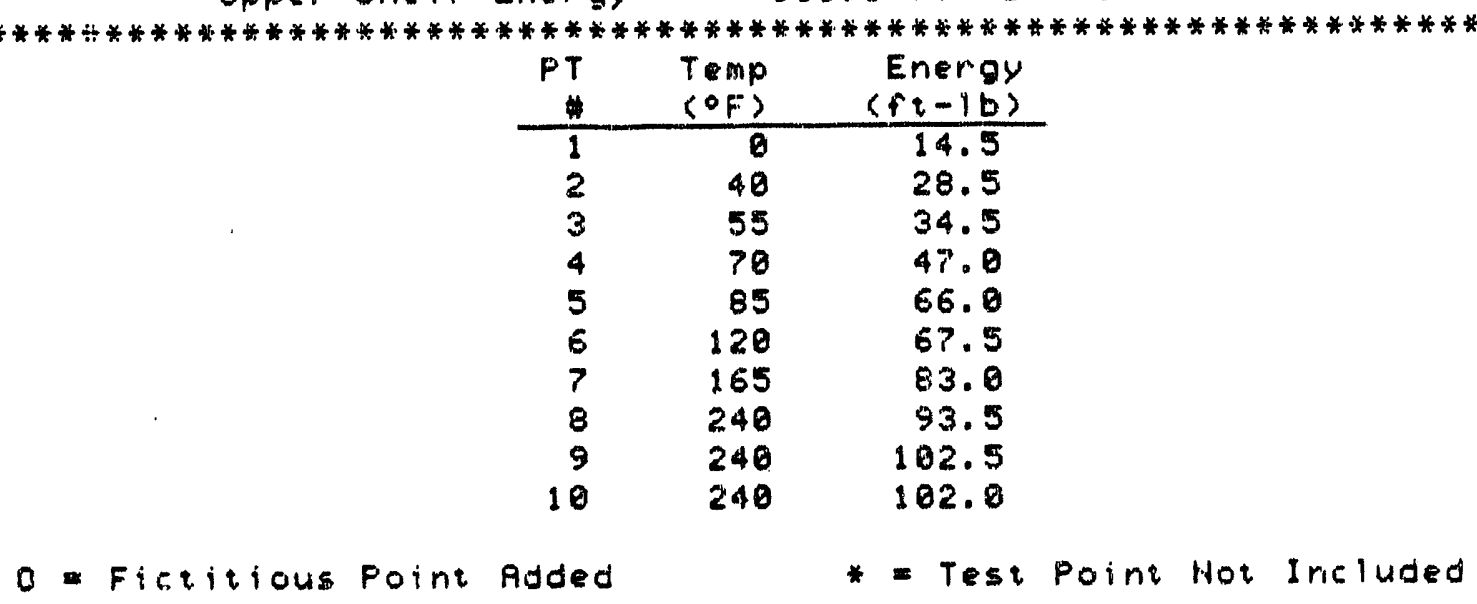




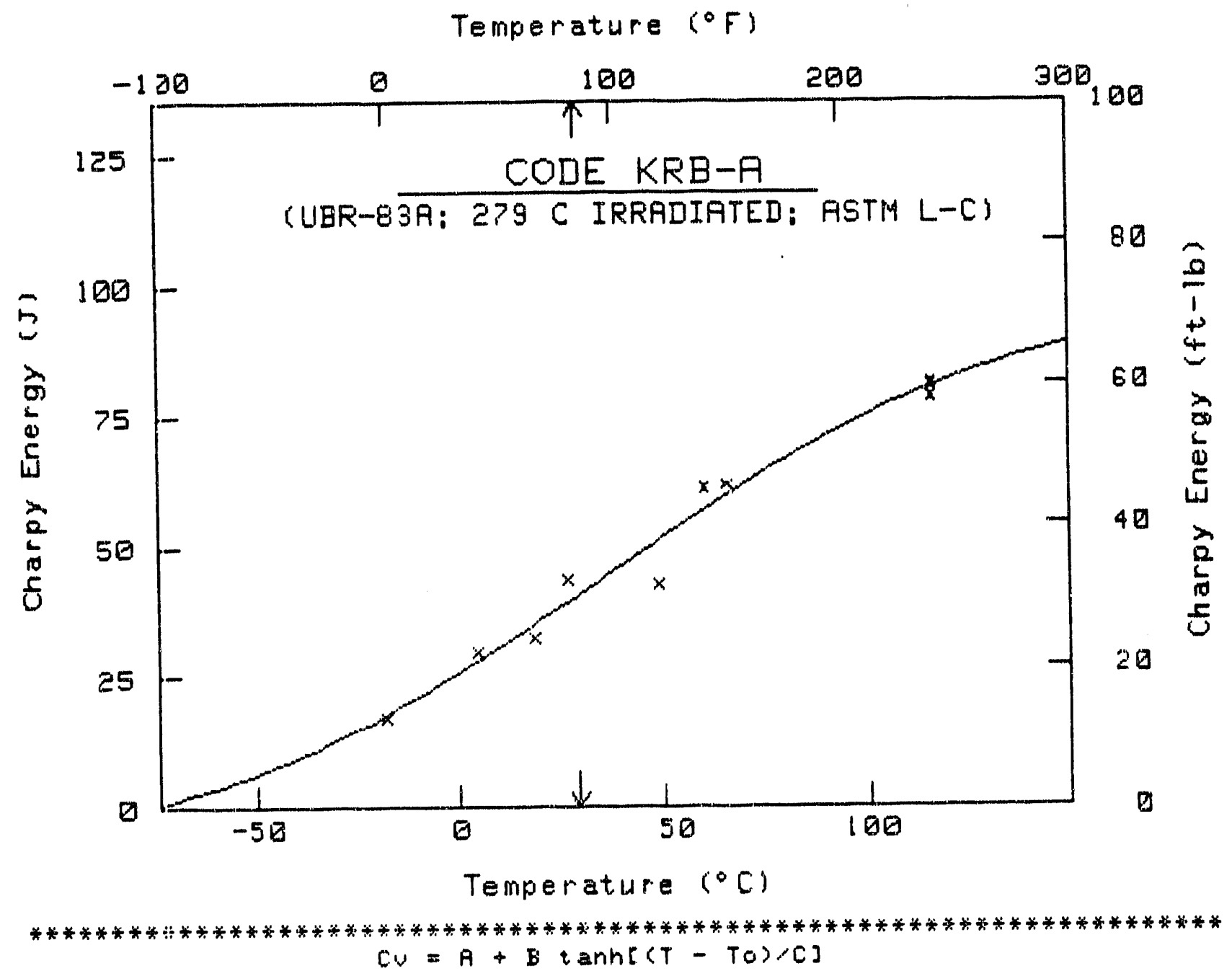

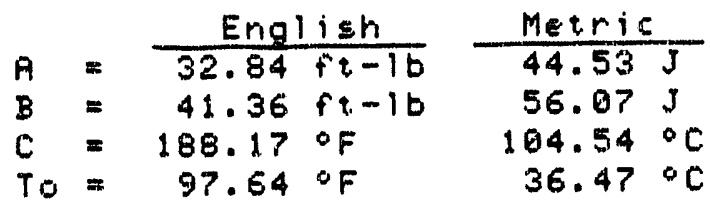

$$
\begin{aligned}
& C v=30 \mathrm{ft}-1 \mathrm{~b}(41 \mathrm{~J}) \mathrm{t} T=84 . \mathrm{T}^{\circ} \mathrm{F} \quad 29.3^{\circ} \mathrm{C} \\
& \text { Upper Sheif Energy }=74.2 \mathrm{ft}-1 \mathrm{~b} 100.6 \mathrm{~J}
\end{aligned}
$$



\begin{tabular}{rrr}
$P T$ & $\begin{array}{r}\text { Temp } \\
\text { (OF) }\end{array}$ & $\begin{array}{r}\text { Energy } \\
(f t-10)\end{array}$ \\
\hline 1 & 0 & 12.5 \\
2 & 40 & 22.0 \\
3 & 65 & 24.0 \\
4 & 80 & 32.0 \\
5 & 120 & 31.5 \\
6 & 140 & 45.0 \\
7 & 150 & 45.5 \\
8 & 240 & 58.0 \\
9 & 240 & 60.0 \\
10 & 240 & 59.5
\end{tabular}

$0=$ Fictitious Point Added

* Test Point Not Included 
Specimen Locations in Archive GEB-2 Material 


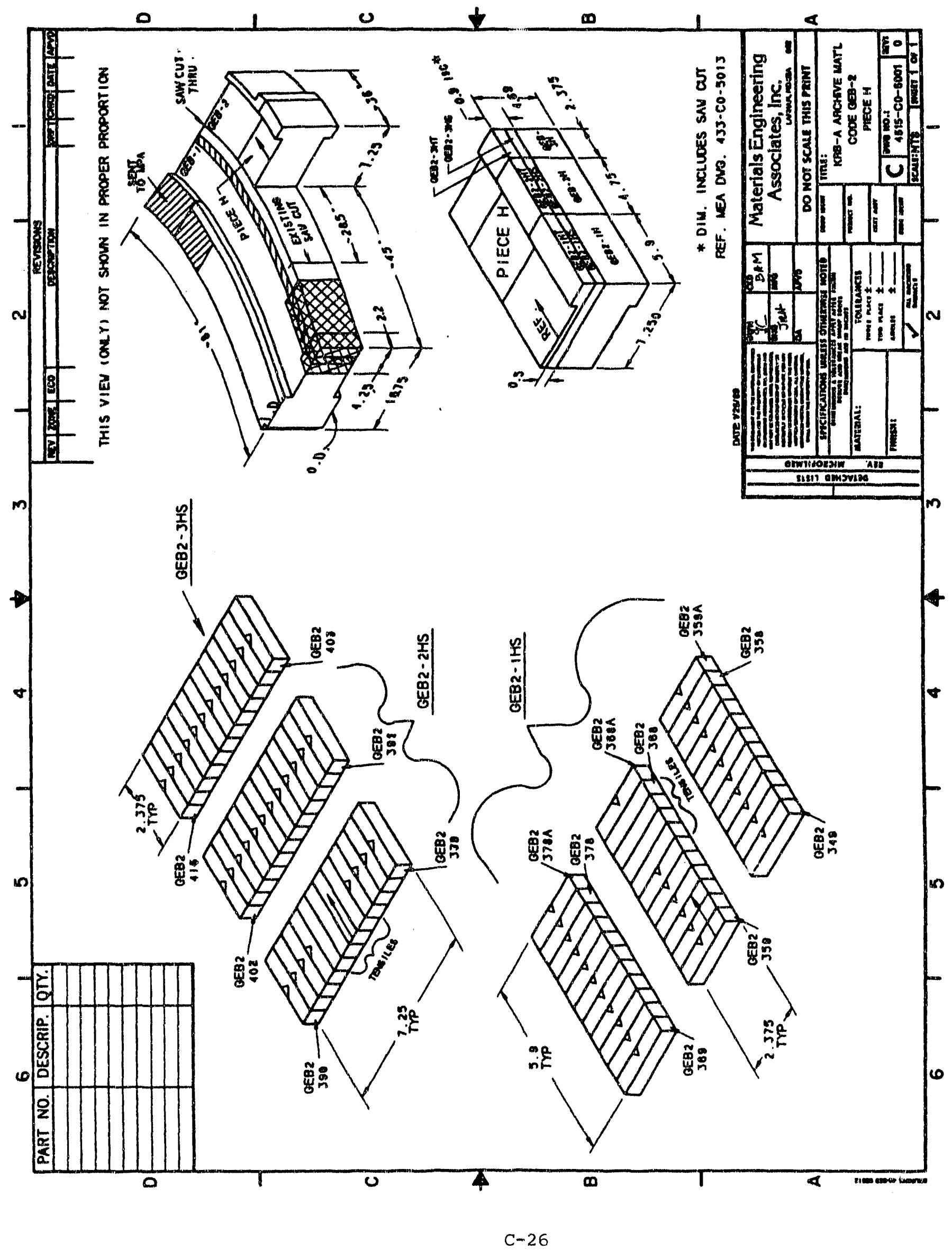




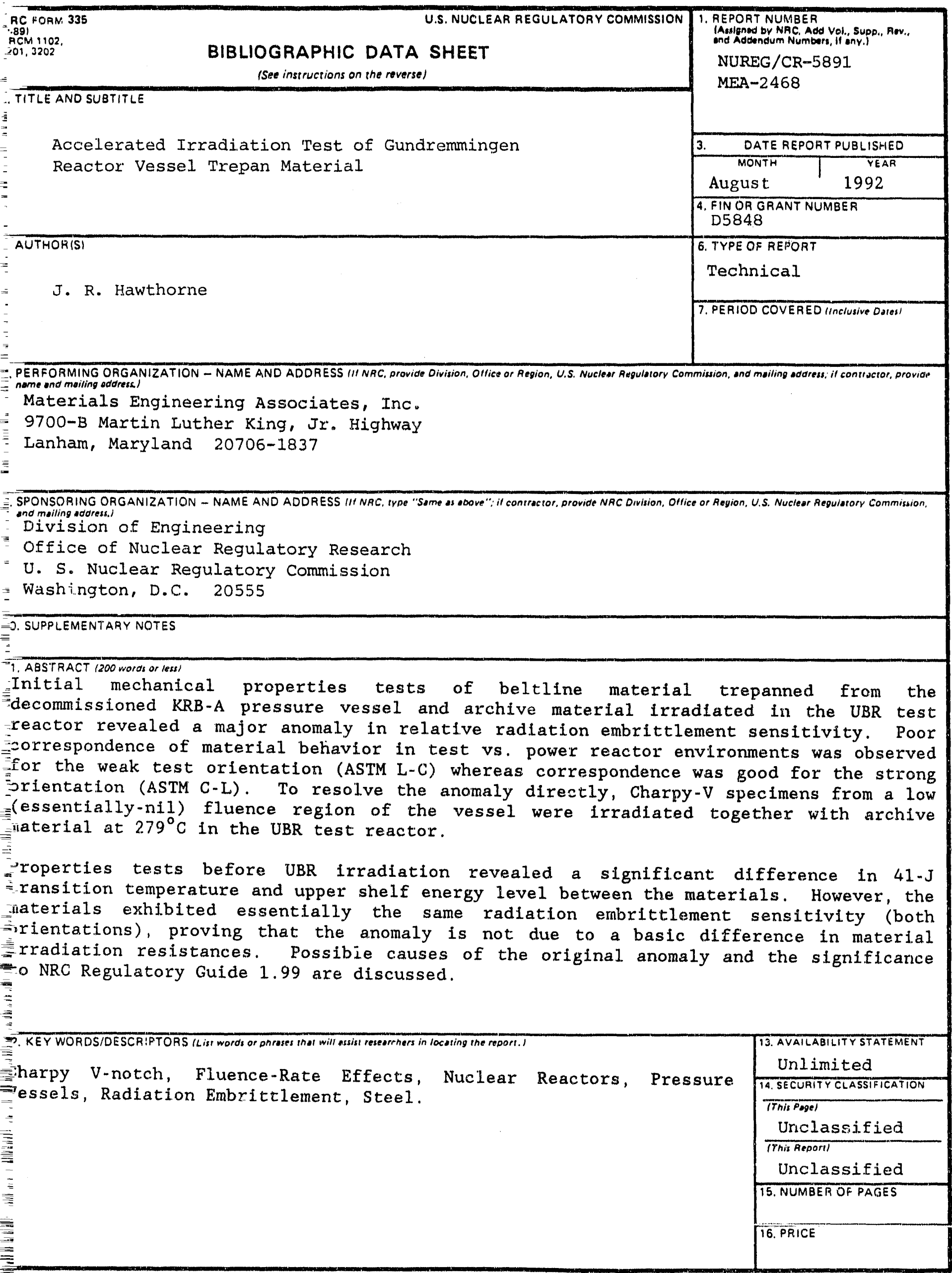





1

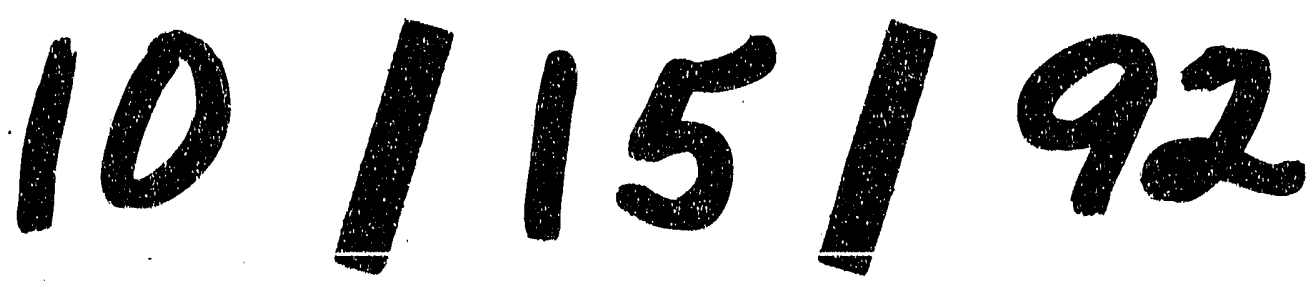




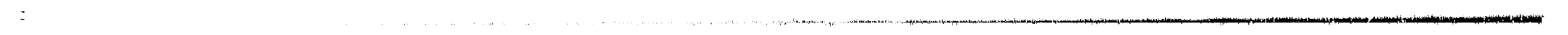

